\title{
LONG-TERM SURVEILLANCE PLAN FOR THE Ambrosia Lake, New Mexico DISPOSAL SITE
}

November 1995

os $\pi$ 
INTENDED FOR PUBLIC RELEASE

This report has been reproduced from the best available copy. Available in paper copy and microfiche

Number of pages in this report: 134

DOE and DOE contractors can obtain copies of this report from:

Office of Scientific and Technical Information

P.0. Box 62

Oak Ridge, TN 37831

(615) 576-8401

This report is publicly available from:

\author{
National Technical Information Service \\ Department of Commerce \\ 5285 Port Royal Road \\ Springfield, VA 22161 \\ (703) $487-4650$
}

\title{
DISCLAIMER
}

This report was prepared as an account of work sponsored by an agency of the United States Government. Neither the United States Government nor any agency thereof, nor any of their employees, makes any warranty, express or implied, or assumes any legal liability or responsibility for the accuracy, completeness, or usefulness of any information, apparatus, product, or process disclosed, or represents that its use would not infringe privately owned rights. Reference herein to any specific commercial product, process, or service by trade name, trademark, manufacturer, or otherwise does not necessarily constitute or imply its endorsement, recommendation, or favoring by the United States Government or any agency thereof. The views and opinions of authors expressed herein do not necessarily state or reflect those of the United States Government or any agency thereof. 


\section{DISCLAMMIER}

Portions of this document may be illegible in electronic image products. Images are produced from the best available original document. 
Prepared for U.S. Department of Energy Environmental Restoration Division UMTRA Project Team Albuquerque, New Mexico

Prepared by Jacobs Engineering Group Inc. Albuquerque, New Mexico 
TABLE OF CONTENTS

Section

$1.0 \quad$ INTRODUCTION............................................................................... $1-1$

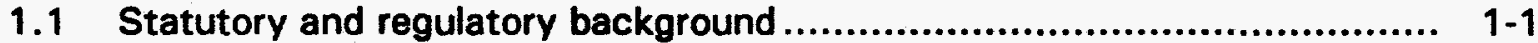

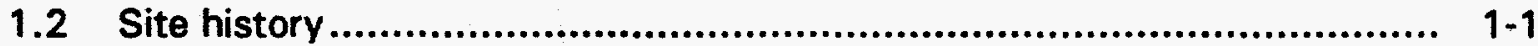

1.3 Site acquisition and licensing ...................................................... $1-3$

1.4 Long-term surveillance program ................................................. $1-3$

2.0 FINAL SITE CONDITIONS........................................................... $2-1$

2.1 Description of the disposal site vicinity .......................................... $2-1$

2.2 Disposal site description............................................................. $2-3$

2.3 Disposal site access and security ................................................ $2-3$

2.4 Disposal cell design ................................................................ $2-5$

2.5 Description of adjacent areas.................................................... $2-6$

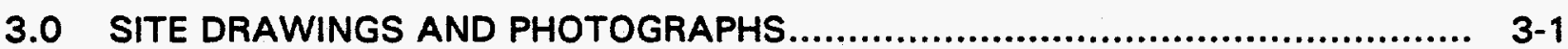

3.1 Disposal site baseline map.......................................................... 3-1

3.2 Disposal site as-built drawings ............................................... $3-2$

3.3 Site baseline photographs ...................................................... $3-2$

3.4 Site inspection maps and photographs ....................................... $3-2$

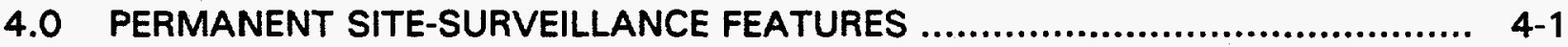

4.1 Survey monuments............................................................ 4-1

4.2 Boundary monuments ......................................................... 4-1

4.3 Site markers ........................................................................ 4-1

4.4 Warning signs .................................................................... 4-1

4.5 Displacement monuments ..................................................... 4-8

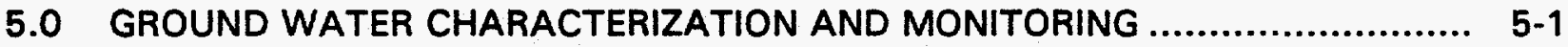

5.1 Ground water characterization ............................................... $5-1$

5.1 .1 Climate and surface features .......................................... 5-1

5.1 .2 Human activities ......................................................... $5-1$

5.1 .3 Hydrostratigraphy...................................................... $5-2$

5.1 .4 Background ground water quality ..................................... 5-16

5.1.5 Ground water quality and extent of contamination .................... 5-17

5.2 Ground water monitoring plan................................................. 5-22

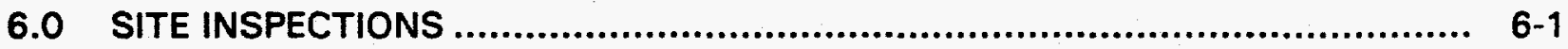

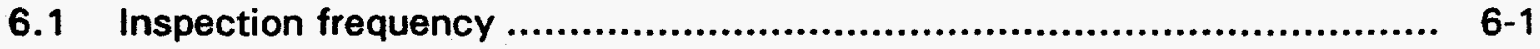

6.2 Inspection team ................................................................. $6-1$

6.3 Preparation for inspection.......................................................... 6-2

6.4 Routine site inspection............................................................ $6-2$

6.4.1 On-site areas ................................................................. $6-3$

6.4 .2 Off-site areas............................................................... $6-4$

6.5 Site inspection documentation ................................................ 6-4

6.5.1 Site inspection checklist................................................ 6-4 


\section{TABLE OF CONTENTS (Concluded)}

Section

6.5.2 Site inspection maps ............................................................. 6-5

6.5.3 Site inspection photographs................................................. 6-6

6.5.4 Site inspection report........................................................... 6-7

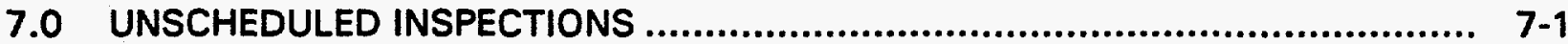

7.1 Follow-up inspections ................................................................ 7

7.2 Contingency inspections ........................................................ $7-1$

7.3 Documentation requirements ...................................................... $7-1$

8.0 CUSTODIAL MAINTENANCE OR REPAIR ............................................... 8-1

8.1 Unscheduled maintenance or repair ................................................ 8-1

8.2 Documentation requirements ...................................................... $8-1$

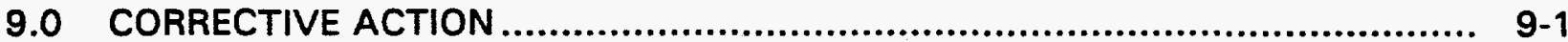

9.1 Problem identification and evaluation............................................ $9-1$

9.2 Corrective action implementation ................................................... 9-1

9.3 Documentation requirements ..................................................... 9-2

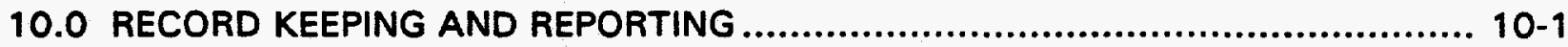

10.1 Record keeping requirements ...................................................... 10-1

10.2 Reporting requirements .................................................................. 10-1

11.0 EMERGENCY NOTIFICATION AND RESPONSE ........................................... 11-1

11.1 Agency agreements..................................................................... 11

11.2 Notification triggers ...................................................................... 11-1

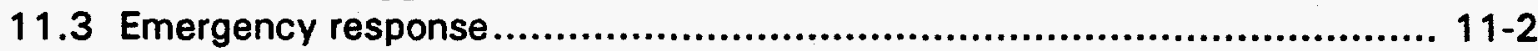

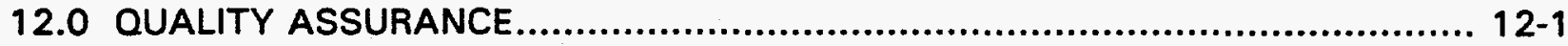

13.0 PERSONNEL HEALTH AND SAFETY .................................................... 13-1

13.1 Health and safety during inspections ......................................... 13-1

13.2 Reportable incidents ................................................................. 13-4

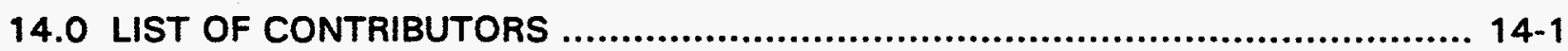

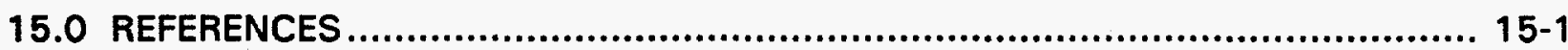

ATTACHMENT 1 - NRC CONCURRENCE DOCUMENTATION

ATTACHMENT 2 - SITE REAL ESTATE INFORMATION

ATTACHMENT 3 - SITE INSPECTION PHOTO LOG

ATTACHMENT 4 - SITE INSPECTION CHECKLIST

ATTACHMENT 5 - AGENCY NOTIFICATION AGREEMENTS 


\section{LIST OF FIGURES}

Figure

Page

1.1 Ownership of the disposal site and adjacent areas, Ambrosia Lake,

New Mexico, site

2.1 Location map, Ambrosia Lake, New Mexico, site...................................... 2-2

2.2 Vicinity map, Ambrosia Lake, New Mexico, site ........................................ 2-4

4.1 Survey monument, Ambrosia Lake, New Mexico, site ............................... 4-3

4.2 Boundary monument, Ambrosia Lake, New Mexico, site................................ 4-4

4.3 Site marker message, Ambrosia Lake, New Mexico, site .............................. 4-5

4.4 Site marker at entrance, Ambrosia Lake, New Mexico, site ............................ 4-6

4.5 Site marker at disposal cell crest, Ambrosia Lake, New Mexico, site................ 4-7

4.6 Entrance warning sign, Ambrosia Lake, New Mexico, site ............................ 4-9

4.7 Perimeter warning sign, Ambrosia Lake, New Mexico, site ........................... 4-10

4.8 Mining restriction warning sign, Ambrosia Lake, New Mexico, site ................. 4-11

4.9 Displacement monument, Ambrosia Lake, New Mexico, site........................ 4-12

5.1 Generalized regional geologic cross section, Ambrosia Lake, New Mexico, site

5.2 Location of monitor wells and former/current site features, Ambrosia Lake, New Mexico, site ....................................................................... $5-5$

5.3 Hydrogeologic cross section A-A', Ambrosia Lake, New Mexico, site.............. 5-6

5.4 Relationship between geologic and hydrostratigraphic units, Ambrosia Lake, New Mexico, site

5.5 Hydrograph showing ground water elevation trends in monitor wells completed in the alluvium/weathered Mancos Shale hydrostratigraphic unit, Ambrosia Lake, New Mexico, site

5.6 Ground water surface map for alluvium/weathered Mancos Shale, Ambrosia Lake, New Mexico, site

5.7 Potentiometric surface map for Tres Hermanos- $C_{1}$ Sandstone, Ambrosia Lake, New Mexico, site.

5.8 Potentiometric surface map for Tres Hermanos $-C_{2}$ Sandstone, Ambrosia Lake, New Mexico, site.

5.9 Sulfate isopleth map for ground water in the alluvium/weathered Mancos Shale, Ambrosia Lake, New Mexico, site

5.10 Sulfate isopleth map for ground water in the Tres Hermanos- $C_{2}$ Sandstone, Ambrosia Lake, New Mexico, site

13.1 Emergency route to Cibola General Hospital from Ambrosia Lake, New Mexico, site 


\section{LIST OF PLATES}

\section{Plate}

1 Disposal site map, Ambrosia Lake, New Mexico, site

\section{LIST OF TABLES}

Table

2.1 Ambrosia Lake disposal site access contacts .................................... $2-5$

3.1 Final aerial photography for the Ambrosia Lake disposal site ........................ 3-3

4.1 Locations of permanent surveillance features, Ambrosia Lake, New Mexico, site

5.1 Summary of hydraulic properties of hydrostratigraphic units at the Ambrosia Lake, New Mexico, site.

5.2 Maximum observed concentrations of listed constituents in monitor wells located in the alluvium/weathered Mancos Shale at the Ambrosia Lake, New Mexico, site, 1980 to 1994

5.3 Maximum observed concentrations of listed constituents in monitor wells located in the Tres Hermanos- $C_{1}$ Sandstone at the Ambrosia Lake, New Mexico, site, 1980 to 1994

5.4 Maximum observed concentrations of listed constituents in monitor wells located in the Tres Hermanos- $\mathrm{C}_{2}$ Sandstone at the Ambrosia Lake, New Mexico, site, 1980 to 1994

6.1 Revegetation seeding mixes, Ambrosia Lake, New Mexico, site 


\section{LIST OF ACRONYMS}

Acronym

DOE

EPA

GJPO

LTSP

$\mathrm{MCL}$

NGVD

NRC

OMC

UMTRA

UMTRCA

UNC

UPDCC

USACE

\section{Definition}

U.S. Department of Energy

U.S. Environmental Protection Agency

Grand Junction Projects Office

long-term surveillance plan

maximum concentration limit

National Geodetic Vertical Datum

U.S. Nuclear Regulatory Commission

Quivira Mining Company

Uranium Mill Tailings Remedial Action

Uranium Mill Tailings Radiation Control Act

United Nuclear Corporation

UMTRA Project Document Control Center

U.S. Army Corps of Engineers 


\subsection{INTRODUCTION}

This long-term surveillance plan (LTSP) for the Uranium Mill Tailings Remedial Action (UMTRA) Project Ambrosia Lake disposal site in McKinley County, New Mexico, describes the U.S. Department of Energy's (DOE) long-term care program for the disposal site. The DOE will carry out this program to ensure that the disposal cell continues to function as designed. This LTSP was prepared as a requirement for acceptance under the U.S. Nuclear Regulatory Commission (NRC) general license for custody and long-term care of residual radioactive materials.

\section{$1.1 \quad$ STATUTORY AND REGULATORY BACKGROUND}

Title I of the Uranium Mill Tailings Radiation Control Act (UMTRCA) of 1978 (42 USC $\$ 7901$ et seq.) authorized the DOE to perform remedial actions at 24 inactive uranium mill tailings sites to reduce the potential effect on public health from the unstabilized residual radioactive materials in and around the uranium mill tailings sites. Residual radioactive materials are any wastes that the DOE determines to be radioactive, either in the form of tailings resulting from the processing of ores for the extraction of uranium and other valuable constituents of the ores, or in other forms that relate to such processing, such as sludge and captured contaminated water from these sites (60 FR 2854).

In accordance with Section 275 of the Atomic Energy Act 142 USC $\$ 2011$ et seq.) as amended by the UMTRCA, the U.S. Environmental Protection Agency (EPA) has promulgated health and environmental protection standards for residual radioactive material cleanup and disposal in 40 CFR Part 192. These standards were originally promulgated in 1983 (48 FR 602). Portions of the standards covering ground water protection were remanded by the U.S. Court of Appeals for the Tenth Circuit in 1985. The EPA issued replacement ground water standards on 11 January 1995, with publication of a final rule (60 FR 2854).

The NRC has developed regulations for the issuance of a general license for the custody and long-term care of residual radioactive material disposal sites in 10 CFR Part 40. The license is available only to the DOE (or any successor federal agency designated by the President) and has no termination date. The purpose of this general license is to ensure that the UMTRA disposal sites will be cared for in a manner that protects the public health and safety and the environment. The NRC requires the DOE to submit a site-specific LTSP that meets the requirements of 10 CFR $\$ 40.27$ (b) in order for each disposal site to be licensed.

\subsection{SITE HISTORY}

Phillips Petroleum Company built the Phillips Mill at the Ambrosia Lake site in 1957 and operated it from June 1958 until March 1963 using uranium ore from nearby mines. The mines around the site consisted of vertical shafts to the ore body several hundred feet below the surface. While in operation, the mill 
processed over 3 million tons ( 3 million metric tons) of uranium ore. The Phillips Mill used alkaline pressure leach technology to extract uranium from the ore. Uranium leaching occurred in tanks. Drum filters separated uranium from solution and waste was pumped to a nearby tailings pile. Following purchase of the mill by United Nuclear Corporation (UNC), all operations were scaled back and milling ceased in April 1963. UNC used portions of the mill as a resin ion exchange facility to extract uranium from mine water until 1982 when all site operations ceased.

During the 5-year operational period, the Phillips Mill produced about 3.0 million tons (2.7 million metric tons) of tailings. Some 0.40 million tons 10.36 million metric tons) of tailings were subsequently used to backfill the former Ann Lee Mine No. 1, which is located just outside the disposal site's north boundary (Plate 1).

The Ambrosia Lake uranium mill tailings site was one of the 24 sites identified for remediation in the UMTRCA. The DOE and the state of New Mexico entered into a cooperative agreement under the UMTRCA, establishing terms and conditions of the remedial action (DOE, 1985). The DOE evaluated the environmental impacts associated with the Ambrosia Lake site remedial action in an environmental assessment (DOE, 1987). The NRC and the state of New Mexico concurred with the DOE's remedial action plan (DOE, 1991) to comply with the requirements of 40 CFR Part 192, Subparts A-C.

The DOE conducted surface remedial action at the Ambrosia Lake site in two phases. Remedial action began in 1987 with site preparation followed by asbestos removal and demolition of the former mill buildings and processing facilities. After a hiatus of several years, remedial action resumed: In 1992, 2.7 million cubic yards $\left(\mathrm{yd}^{3}\right)$ (2.1 million cubic meters $\left.\left[\mathrm{m}^{3}\right]\right)$ of relocated tailings, contaminated demolition debris and contaminated windblown material were consolidated with 2.4 million $\mathrm{yd}^{3}\left(1.9\right.$ million $\left.\mathrm{m}^{3}\right)$ of tailings that were stabilized in place (MK-F, 1995). Remedial action that consolidated tailings and contaminated materials, placed them in a disposal cell, and covered them with a radon/infiltration barrier and an erosion protection layer, was completed in June 1995.

The UMTRA Remedial Action Contractor has prepared a completion report documenting compliance with the remedial action plan and the site as-built conditions (MK-F, 1995). The DOE will prepare a final audit report and certification summary and submit it along with the completion report to the NRC for concurrence. Concurrence from the NRC on the certification report will be included (when received) in Attachment 1 of this LTSP.

The DOE also is required to demonstrate compliance with 40 CFR Part 192 , Subparts B and C, as revised by 60 FR 2854, for cleanup of existing ground water contamination. The DOE UMTRA Ground Water Project will address the need for remedial action involving residual ground water contamination at the 
Ambrosia Lake site. The DOE's final determination will be made in a separate National Environmental Policy Act (42 USC $\$ 4321$ et seq.) document.

\section{$1.3 \quad$ SITE ACQUISITION AND LICENSING}

The state of New Mexico currently owns the Ambrosia Lake site. The title documentation is being reviewed by the U.S. Army Corps of Engineers prior to accepting transfer of the site to the federal government. Attachment 2 provides a legal description of the Ambrosia Lake disposal site to be conveyed to the DOE for long-term care and ownership. Figure 1.1 shows the final site boundary and identifies ownership of the site and surrounding areas at the time of licensing.

The general license becomes effective when the NRC concurs with the DOE's determination of completion of remedial action at the Ambrosia Lake site, ownership of the site is transferred to the federal government, and the NRC formally accepts this LTSP. After the general license becomes effective for the Ambrosia Lake disposal site, the DOE will transfer responsibility for the longterm surveillance program to its Grand Junction Projects Office (GJPO) in Grand Junction, Colorado. The programmatic transfer will occur within 90 days of NRC notification that the license is in effect.

\subsection{LONG-TERM SURVEILLANCE PROGRAM}

This LTSP describes the DOE's long-term surveillance program to be implemented at the Ambrosia Lake disposal site to ensure that the disposal site continues to perform as designed. The plan is based on the UMTRA Project long-term surveillance program guidance (DOE, 1992a) and meets the requirements of 10 CFR $\$ 40.27(\mathrm{~b})$ by addressing the following:

- Site description and ownership.

- Description of final site conditions.

- Site inspection procedures and personnel.

- Custodial maintenance and corrective actions programs.

- Record keeping and reporting.

- Emergency response.

- Quality assurance. 


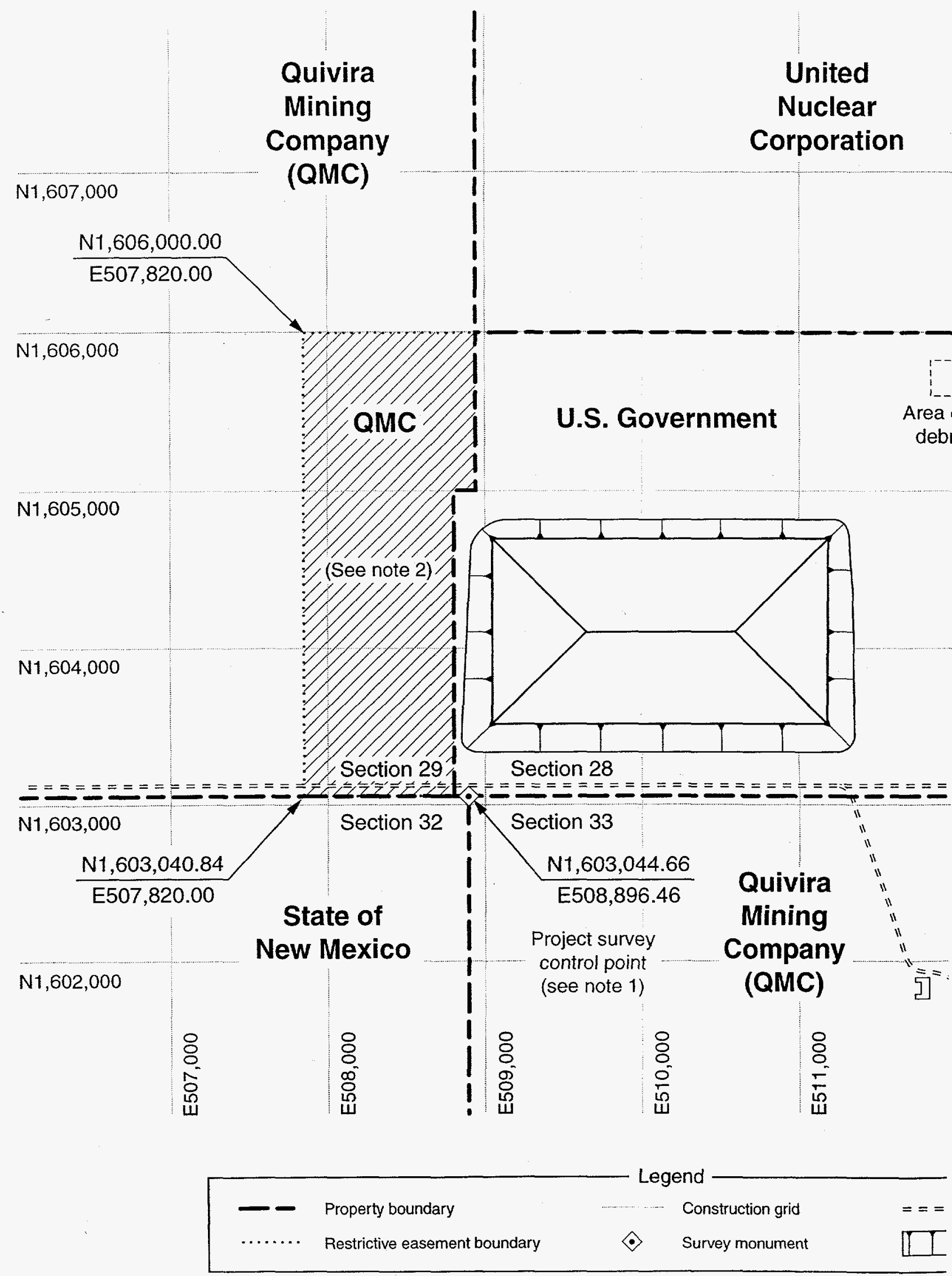


Figure 1.1

Ownership of Disposal Site and Adjacent Areas

Ambrosia Lake, New Mexico, Site

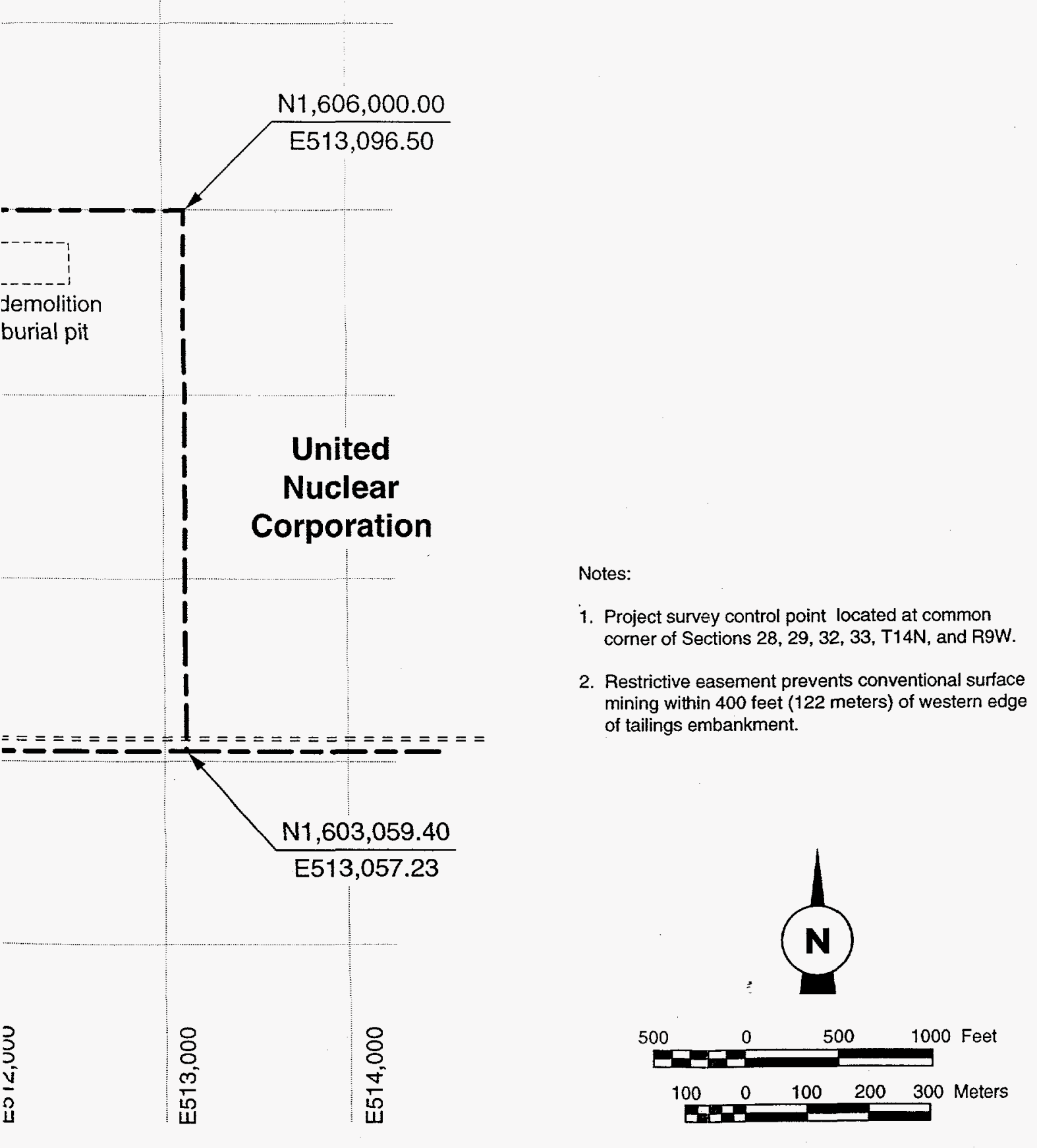

Existing dirt road

Disposal cell 


\subsection{FINAL SITE CONDITIONS}

Remedial action at the Ambrosia Lake site consisted of stabilizing the majority of the tailings in place. Contaminated demolition debris from the former mill and soil from surrounding areas that was contaminated with windblown tailings were also cleaned up. A rock-covered disposal cell was constructed in the southwestern portion of the designated processing site to control the residual radioactive material in accordance with 40 CFR Part 192. The Ambrosia Lake disposal site is unfenced, but its perimeter is marked with warning signs. The site completion report (MK-F, 1995) contains a detailed description of the final site conditions.

\subsection{DESCRIPTION OF THE DISPOSAL SITE VICINITY}

The Ambrosia Lake disposal site is in McKinley County in northwest New Mexico. The site is approximately 25 miles (mi) (40 kilometers [km]) north of Grants, New Mexico, accessible via state highways (Figure 2.1).

The disposal site is situated in the Ambrosia Lake Valley, on the southern edge of the San Juan Basin portion of the Colorado Plateau, at an elevation of about 7000 feet ( $\mathrm{ft}$ ) (2100 meters [m]) National Geodetic Vertical Datum (NGVD). The topography of the area surrounding the site consists of a broad valley trending northwest to southeast bounded by elongated mesas that rise to an elevation of about $8000 \mathrm{ft}(2400 \mathrm{~m})$ NGVD. Several small ephemeral streams and channels originating in the canyons to the northeast direct the surface runoff in the immediate area to the southwest. The site lies within the drainage basin of the Arroyo del Puerto, an intermittent stream about $1 \mathrm{mi}(1.6 \mathrm{~km})$ southwest of the site. The Arroyo del Puerto flows into San Mateo Creek about $5 \mathrm{mi}(8 \mathrm{~km})$ south of the site. There are no perennial streams in the vicinity of the Ambrosia Lake disposal site.

The valley has a semiarid climate characterized by low precipitation, abundant sunshine, low relative humidity, and large diurnal and annual temperature ranges (DOE, 1991). Annual precipitation is about 9 inches (20 centimeters [cm]). Normally over one-half of the annual precipitation occurs from July to September, usually during brief, intense thunderstorms. Annual lake evaporation is estimated to be 54 in $(140 \mathrm{~cm})$ for the region. Temperatures range from below 0 degrees Fahrenheit $\left({ }^{\circ} \mathrm{F}\right)\left(-20\right.$ degrees Celsius $\left.\left[{ }^{\circ} \mathrm{C}\right]\right)$ in the winter to over $100^{\circ} \mathrm{F}\left(40^{\circ} \mathrm{C}\right)$ in the summer. Winds average about $6 \mathrm{mi}(10 \mathrm{~km})$ per hour and are predominately from the west and north-northwest.

Over the last decade, surface use of the land in the vicinity of the Ambrosia Lake site has shifted from uranium mining and milling to livestock grazing. Other potential future surface uses include pasture cultivation. 
Figure 2.1

Location Map, Ambrosia Lake, New Mexico, Site

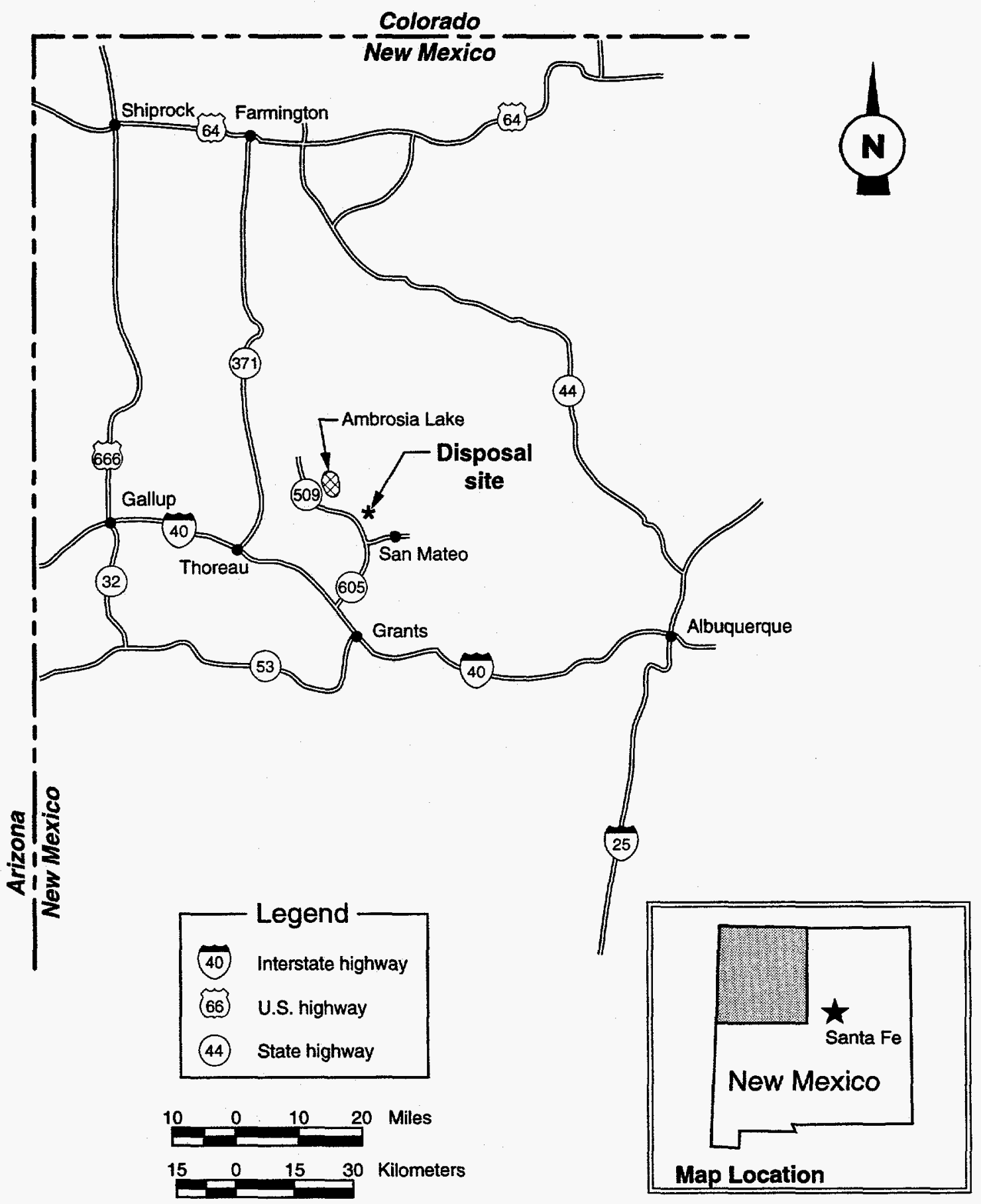

MAC: SITEIAMBRTSPISITELOC 


\subsection{DISPOSAL SITE DESCRIPTION}

The Ambrosia Lake disposal site is located on approximately 290 acres (ac) (120 hectares [ha]) of land located in the southern half of Section 28. Township 14 North, Range 9 West, New Mexico Prime Meridian (Figure 2.2). Attachment 2 contains the legal description of the disposal site.

The Ambrosia Lake disposal site is roughly rectangular in shape and has an eastwest length of about $4200 \mathrm{ft}(1300 \mathrm{~m})$ and a north-south width of about $2900 \mathrm{ft}(880 \mathrm{~m})$. The tailings and other contaminated materials are covered with a layer of compacted earth to inhibit radon emanation and water infiltration and an outer layer of rock for erosion protection. The perimeter of the disposal site is marked with warning signs, boundary markers, and survey monuments (Section 4.0).

\subsection{DISPOSAL SITE ACCESS AND SECURITY}

The Ambrosia Lake disposal site can be accessed by automobile on wellmaintained highways following these directions:

- From Albuquerque, New Mexico, take Interstate 40 west about $75 \mathrm{mi}$ $(120 \mathrm{~km}$ ) to Exit 79 (Milan/San Mateo/NM 122/NM 605).

- Go right (north) $0.1 \mathrm{mi}(0.2 \mathrm{~km})$ to NM 122 (historic U.S. Highway 66), turn left (west) and go $0.1 \mathrm{mi}(0.2 \mathrm{~km})$ on NM 122 to NM 605 following signs for Ambrosia Lake (see Figure 13.1).

- Turn right onto NM 605 and travel about $14 \mathrm{mi}(22 \mathrm{~km})$ to NM 509.

- From NM 605, turn left onto NM 509 and travel northwest for $4.6 \mathrm{mi}$ $(7.4 \mathrm{~km})$.

- Turn right onto an unmarked east-west graded dirt road with power lines along both sides and travel east about $1 \mathrm{mi}(1.6 \mathrm{~km})$ to the site, located just past a cattle guard on the road.

The east-west dirt access road follows the section line between Sections 28 and 33, which forms the south boundary of the disposal site (Figure 2.2). Presently, entry to the disposal site is restricted only by means of warning signs; there is no fence around the perimeter of the site. However, the access road is privately owned by Quivira Mining Company (OMC). While OMC has granted the DOE permission to use the road, OMC should be notified prior to visiting the site. OMC has indicated that it may close the access road at NM 509 with a gate, at which time the GJPO will obtain a key from QMC. In addition, permission to access the site shall be obtained from either the DOE UMTRA Team Site Manager or the GJPO Supervisory General Engineer (Table 2.1). 
Figure 2.2

Vicinity Map, Ambrosia Lake, New Mexico, Site

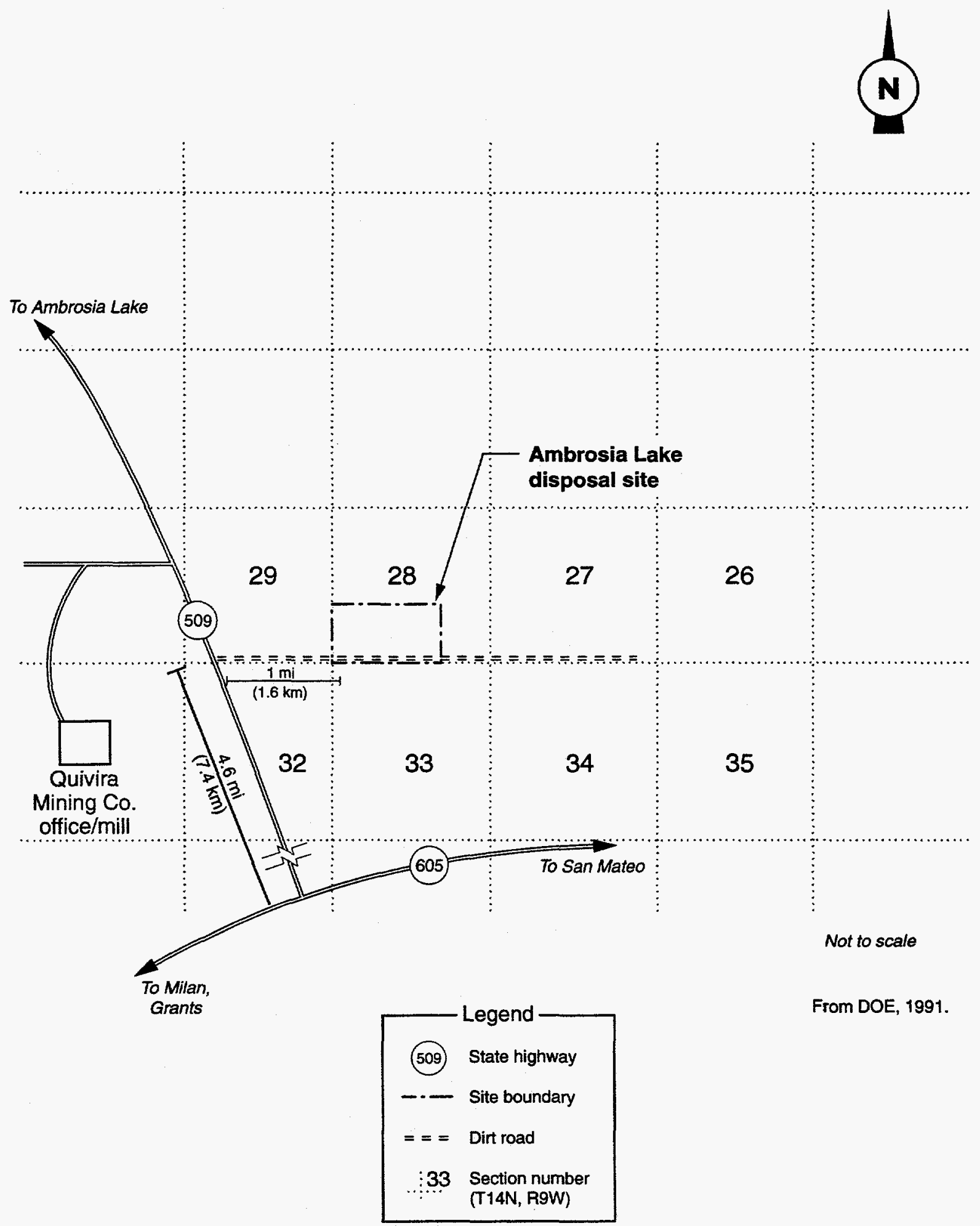

MAC: SITE/AMBLTSP OCAMBLAKE 
Table 2.1 Ambrosia Lake disposal site access contacts

\begin{tabular}{ccl}
\hline Title of contact & \multicolumn{1}{c}{ Telephone } & \multicolumn{1}{c}{ Address } \\
\hline DOE UMTRA Team Site Manager & $505-845-4022$ & U.S. Department of Energy \\
& & Albuquerque Operations Office \\
& & Environmental Restoration Division \\
& & Post Office Box 5400 \\
& & Albuquerque, NM 87115 \\
Supervisory General Engineer & $970-248-6006$ & U.S. Department of Energy \\
& & Grand Junction Projects Office \\
& & 2597 B 3/4 Road \\
& & Grand Junction, CO 81503 \\
\hline
\end{tabular}

The effectiveness of site security measures will be monitored through scheduled site inspections (Section 6.0). A DOE 24-hour telephone number on the entrance sign (Section 4.0) and agreements with local agencies to notify the DOE in the event of an emergency or breach of site integrity (Section 11.0) serve as additional security measures. Because of the remote location of the disposal site, purposeful intrusion is not expected; however, if intrusion, vandalism, or other factors become a problem, site security will be reevaluated.

2.4 DISPOSAL CELL DESIGN

The disposal cell is located on a low-gradient alluvial slope upland from the main active valley stream channel. Erosion processes operating in the active channel will not conceivably affect the tailings pile within the projected stabilization life of 1000 years. The site is also at a great enough distance from nearby mesas to preclude any hazard from slope failure processes such as landslides, debris flows, mud flows, and rockfalls. The geomorphic processes posing a potential hazard to the stabilized site are ephemeral drainage channel changes, lowgradient slope erosion, and wind erosion.

The stabilized disposal cell was constructed above the ground surface; it contains 6.9 million dry tons (6.3 million metric tons), and approximately 5.2 million $\mathrm{yd}^{3}\left(3.9\right.$ million $\left.\mathrm{m}^{3}\right)$ of tailings and contaminated soil and debris. The disposal cell is roughly rectangular with a maximum length of approximately $2500 \mathrm{ft}(760 \mathrm{~m})$ and a maximum width of about $1600 \mathrm{ft}(490 \mathrm{~m})$ including the toe apron (Plate 1). The disposal cell rises to a maximum height of approximately $50 \mathrm{ft}(15 \mathrm{~m})$ above the surrounding terrain.

The main tailings pile was stabilized in place. Relocated contaminated materials were placed on top of the tailings and then covered with a radon/infiltration barrier. The topslopes and sideslopes of the disposal cell were capped with rock to prevent wind and water erosion of the underlying radon/infiltration barrier and tailings. 
A 30-inch $(80-\mathrm{cm})$-thick radon/infiltration barrier was placed over the contaminated materials. This barrier was constructed of clayey soil and is designed to reduce the radon-222 flux from the disposal cell to less than 20 picocuries per square meter per second and minimize the rate of surface water infiltration into the tailings. The thickness of the radon/infiltration barrier, in conjunction with the erosion protection layer, will prevent the disposal cell from being adversely affected by freezing and thawing cycles.

The erosion protection layer is 6-inch $(15-\mathrm{cm})$-thick riprap on the topslopes and 12-inch $(30-\mathrm{cm})$-thick riprap on the sideslopes. The topslopes have Type A riprap with a rock diameter of predominately $2-3$ inches $(5-8 \mathrm{~cm})$; the sideslopes have Type B riprap with a rock diameter of predominately 4-6 inches (10$15 \mathrm{~cm})$. A 6-inch $(15-\mathrm{cm})$-thick bedding layer was placed between the riprap and the radon/infiltration barrier to prevent damage to the barrier by rocks and loss of the fined-grained radon/infiltration barrier material. The maximum grade is 4 percent on the topslopes and 20 percent on the sideslopes. These grades, in conjunction with the bedding layer, will allow excess surface water to run off the disposal cell. The components of both the topslope and sideslope covers are intended to minimize the potential for deep percolation of precipitation into the residual radioactive material.

At the toe of the disposal cell there is a rock apron, varying in thickness from 34 inches $(86 \mathrm{~cm})$ to 66 inches $(170 \mathrm{~cm})$ and primarily constructed of Type C riprap with a rock diameter of predominately $10-12$ inches $(25-30 \mathrm{~cm})$. At the ground surface, riprap protection extends up to $40 \mathrm{ft}(12 \mathrm{~m})$ from the toe of the disposal cell.

\subsection{DESCRIPTION OF ADJACENT AREAS}

The conditions of several features immediately adjacent to the disposal cell or on private property bordering the disposal site are important to note because changes associated with the features may need to be monitored during site inspections. These features are identified on Plate 1.

In the northeast corner of the disposal site there is a landfill pit containing nonradiological and slightly contaminated demolition debris from the processing site (MK-F, 1995). The debris pit is distinguishable only by a slight mound; the pit area was reseeded and mulched.

Three vent shafts to underground mining areas are located in the immediate site area. One is located just inside the north-central boundary of the disposal site. This shaft, which was sealed by UNC prior to start of remedial action, has a spot-welded cover. Another on-site shaft, which has a bolted-on cover, is near the southwest corner of the site. The third vent shaft, which also has a boltedon cover, is located on QMC property just outside the southwest corner of the site. 
The former Ann Lee Mine adit is located on UNC property just outside the north boundary of the disposal site. The mine shaft is reported to have been backfilled by UNC with mine wastes and dirt and is capped with a concrete slab.

The DOE has revegetated areas of the site surrounding the disposal cell and adjacent areas as part of the remedial action plan and agreements with vicinity property owners (DOE, 1991; MK-F, 1995). Final vegetative cover should equal that of surrounding unremediated areas. These revegetated areas are currently fenced with barbed wire and woven wire fencing to prevent livestock grazing while vegetation is reestablishing. After 5 years, QMC has the option to relocate the fencing to follow the western property boundary of the disposal site (Attachment 2). Agreements with OMC give OMC ownership of the fencing to the south and west of the site and require that $O M C$ maintain the fencing and the cattle guard at the site entrance for 5 years (from 1995) (Charlton, 1993 and 1995; Pommerening, 1992). 


\subsection{SITE DRAWINGS AND PHOTOGRAPHS}

At the completion of remedial action, the UMTRA Remedial Action Contractor documented final disposal site conditions with site maps, as-built drawings, and photographs (MK-F, 1995). This information illustrates baseline conditions for comparison to future disposal site conditions.

All original drawings, site maps, and photographs will become part of the Ambrosia Lake permanent site file and be archived by the UMTRA Project Document Control Center (UPDCC), in Albuquerque, New Mexico. At licensing, the DOE will transfer the site file to the GJPO. The disposal site maps and drawings may be further modified by the GJPO, as necessary. The GJPO will be responsible for maintaining the permanent site file and adding any new maps, drawings, and photographs to the site file.

\subsection{DISPOSAL SITE BASELINE MAP}

The Ambrosia Lake disposal site baseline map (Plate 1) was compiled from the final topographic survey map and as-built drawings of the disposal site area. The final topographic survey was conducted in accordance with the DOE long-term surveillance program guidance (DOE, 1992a). The following specifications were used in developing the topographic map: a scale of 1 inch $=200 \mathrm{ft}(1 \mathrm{~cm}=24 \mathrm{~m})$, a contour interval of $2 \mathrm{ft}(0.6 \mathrm{~m})$, and coverage of the disposal site and an area of $0.25 \mathrm{mi}(0.4 \mathrm{~km})$ outside the site perimeter.

In addition to topography, the baseline map defines the following:

- Disposal site property boundaries and access road.

- Outline of the toe and crest of the disposal cell.

- Location of drainage swales.

- Ground water monitor wells.

- $\quad$ Project survey control point.

- Permanent site surveillance features (e.g., monuments, markers, and signs).

- Other on-site features to be inspected (e.g., displacement monuments, vent shafts, debris pit).

- Site grid coordinate system. 
When this site map is updated, the revised map will include the year of revision and the revision number. The Ambrosia Lake disposal site map will serve as the baseline map for site inspections.

\subsection{DISPOSAL SITE AS-BUILT DRAWINGS}

A set of as-built drawings illustrates final disposal cell construction and final disposal site conditions (MK-F, 1995). These drawings may be used to evaluate changes in physical site conditions or the disposal cell over time and to develop corrective action plans, if required.

\subsection{SITE BASELINE PHOTOGRAPHS}

The photographic record of the Ambrosia Lake disposal site includes a series of aerial and ground photographs that provide a baseline visual record of site construction activities and final site conditions to complement the as-built drawings. The final completion report for the disposal site contains a complete set of photographs that documents each phase of construction (MK-F, 1995). The post-construction photographs provide an orientation tool for site inspections and a baseline record of surveillance features.

A set of aerial photographs was taken of the Ambrosia Lake disposal site in September 1995 after surface remedial action was completed (Table 3.1). These photographs will enable inspectors to monitor changes in large-scale site conditions (e.g., erosion patterns, vegetation changes, and land use) over time. The need for new aerial photographs will be evaluated at 5-year intervals from the effective date of the site license. More detailed information on the aerial photography specifications is provided in the DOE long-term surveillance program guidance (DOE, 1992a) and the Ambrosia Lake site surveillance and maintenance subcontract documents (MK-ES, 1992).

\subsection{SITE INSPECTION MAPS AND PHOTOGRAPHS}

Site maps will be prepared and site photographs will be taken as part of the long-term surveillance program site inspections (Sections 6.7 and 6.8). The GJPO will prepare a site inspection map based on the final site baseline maps and drawings. This inspection map will be updated, as necessary, after each site inspection. Each site inspection map will indicate the year of the inspection and the type of inspection.

Photographs will be taken during disposal site inspections to document conditions at the disposal cell and the disposal site. These photographs will provide a continuous record for monitoring changing conditions over time. The photographs can be compared with the baseline photographs to monitor site features. Each photograph will be recorded individually on a site inspection photo log (Attachment 3). An appropriate description of the feature photographed, including azimuth (if necessary), will be entered into the log. 
Table 3.1 Final aerial photography for the Ambrosia Lake disposal site

Area photographed

Products delivered

Flight date

Flight line coverage
Final disposal site plus a minimum of $0.25 \mathrm{mi}(0.4 \mathrm{~km})$ beyond site boundaries. An area of approximately 1000 ac (400 ha).

Two sets of vertical, color infrared stereo, 9- x 9-inch contact prints, scale 1 inch $=200 \mathrm{ft}(1 \mathrm{~cm}=24 \mathrm{~m})$ (representation fraction 1:2400); double-weight, glossy, not trimmed.

One index map, scale 1 inch $=200 \mathrm{ft}(1 \mathrm{~cm}=24 \mathrm{~m})$; flight lines and frame numbers will be provided.

One set of 2 each of low and high oblique photographs (and negatives) in natural color, 8- $\times 10$-inch glossy, double-weight prints or 9- $\times$ 9-inch contact prints.

September 1995.

Flight line extends 15 to 55 percent over site boundaries; 57 to 62 percent average end overlap; 25 percent average side overlap. 



\subsection{PERMANENT SITE-SURVEILLANCE FEATURES}

Survey and boundary monuments, site markers, and warning signs are the permanent longterm surveillance features of the Ambrosia Lake disposal site. In addition, the disposal cell also has displacement monuments, which are permanently installed. Plate 1 shows the locations of these features and Table 4.1 provides their survey grid coordinates.

The construction and emplacement of the site-surveillance features, described below, meet the specifications in the UMTRA Project long-term surveillance program guidance (DOE, 1992a).

\subsection{SURVEY MONUMENTS}

Three survey monuments establish permanent horizontal control based on the New Mexico Western Region State Plane Coordinate Grid System and referenced to the Project Survey Control Point, which is located at an elevation of $6963.58 \mathrm{ft}(2122.52 \mathrm{~m})$ near the southwest corner of the site. The three permanent survey monuments (SM-1, SM-2, and SM-3) are Berntsen RT-1 markers set in concrete with the dimensions shown in Figure 4.1. Magnets in the markers permit easier detection if they become buried over time. The survey monument identification number is stamped on the top of the metal cap.

\subsection{BOUNDARY MONUMENTS}

Eight boundary monuments lie along the final site boundary. The three RT-1 survey monuments serve a dual purpose as boundary monuments (SM-1 as $B M T-1, S M-2$ as BMT-2, and SM-3 as BMT-3). The remaining five boundary monuments (BMT-4 to BMT-8) are Berntsen Model A-1 survey monuments set in concrete with the dimensions shown in Figure 4.2. Magnets are epoxied in the cap and base of the A-1 monuments to allow easier detection if they become buried. The boundary monument identification number is stamped on the top of the metal cap.

\subsection{SITE MARKERS}

Two unpolished granite markers with an incised message identify the Ambrosia Lake disposal site. The message includes a drawing showing the general location of the stabilized disposal cell within the site boundaries, the date of closure, the dry tonnage of tailings, and the amount of radioactivity (Figure 4.3). Site marker SMK-1 near the southwest corner entrance to the site is set in a bed of reinforced concrete that extends $3 \mathrm{ft}(0.9 \mathrm{~m})$ below the ground surface (Figure 4.4). Site marker SMK-2 at the crest of the disposal cell is set in a bed of reinforced concrete that extends to the top of the radon barrier (Figure 4.5).

\subsection{WARNING SIGNS}

A warning sign was placed at the southwest corner entrance to the disposal site near site marker SMK-1. This entrance sign displays the following information: 
Table 4.1 Locations of permanent survelllance features, Ambrosia Lake, New Mexico, site

\begin{tabular}{|c|c|}
\hline Feature & Location Coordinates \\
\hline \multicolumn{2}{|l|}{ Site Markers } \\
\hline SMK-1 & N 1,603,165; E 508,940 \\
\hline SMK-2 & N 1,604,090; E 510,090 \\
\hline \multicolumn{2}{|c|}{ Survey/Boundary Monuments } \\
\hline SM-1/BMT-1 & N 1,603,059; E 513,057 \\
\hline SM-2/BMT-2 & N 1,606,000; E 513,096 \\
\hline SM-3/BMT-3 & N 1,606,000; E 510,000 \\
\hline \multicolumn{2}{|c|}{ Boundary Monuments } \\
\hline BMT-4 & N 1,606,000; E 508,913 \\
\hline BMT-5 & N 1,605,000; E 508,908 \\
\hline BMT-6 & N 1,604,000; E 508,788 \\
\hline BMT-7 & N 1,603,044; E 508,776 \\
\hline BMT-8 & N 1,603,059; E 513,057 \\
\hline \multicolumn{2}{|c|}{ Displacement Monuments } \\
\hline DM-1 & N 1,603,810; E 509,420 \\
\hline DM-2 & N 1,604,080; E 510,000 \\
\hline DM-3 & N 1,604,080; E 510,550 \\
\hline DM-4 & N 1,604,610; E 510,810 \\
\hline DM-5 & N 1,604,300; E 509,720 \\
\hline DM-6 & N 1,604,300; E 510,470 \\
\hline DM-7 & N 1,603,900; E 509,720 \\
\hline DM-8 & N 1,603,900; E 510,470 \\
\hline
\end{tabular}

${ }^{a}$ Coordinates based on Project Survey Control Point (N 1,603,044.66;

E 508,896.46) located at the common corner of Sections 28, 29, 32, and 33, T14N, R9W, New Mexico Prime Meridian. 
Figure 4.1

Survey Monument

Ambrosia Lake, New Mexico, Site

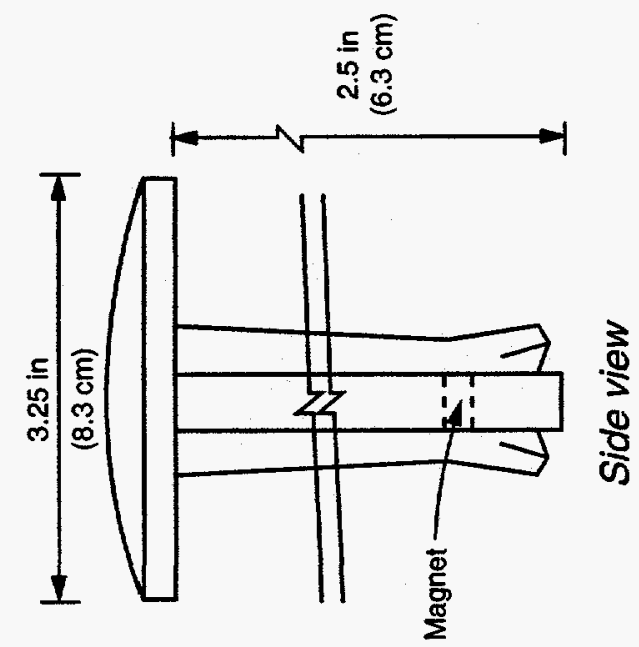

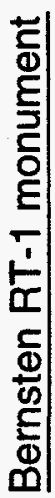
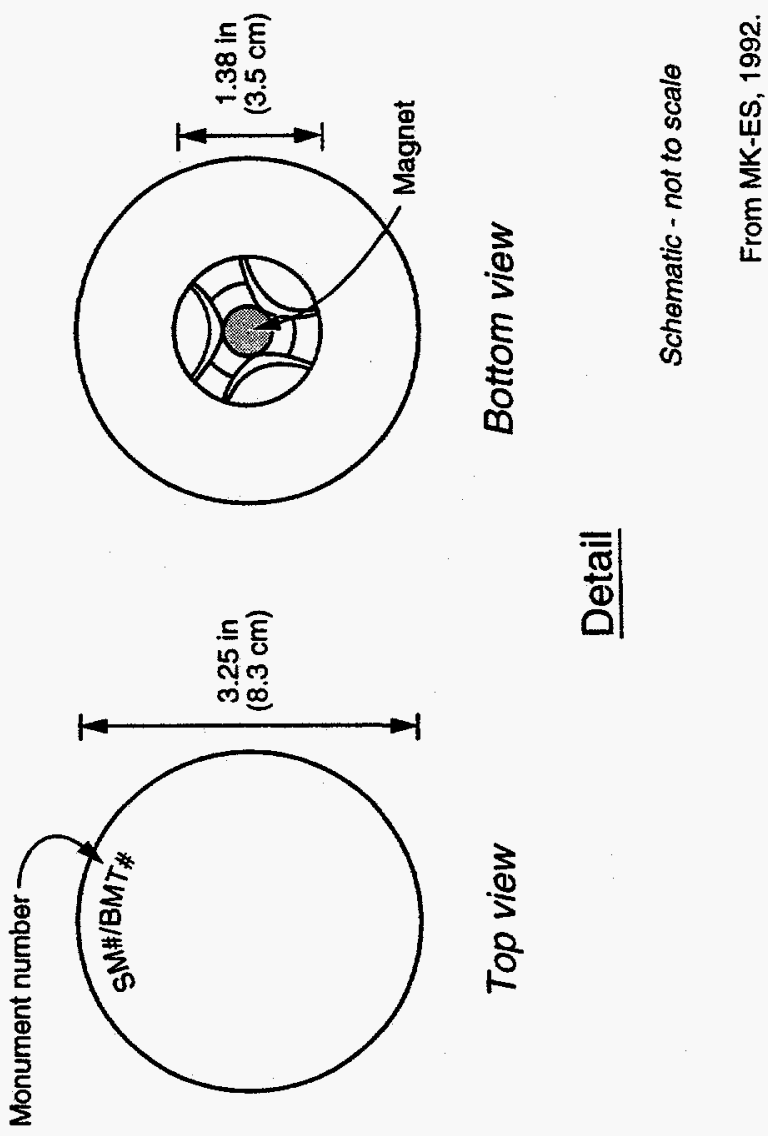

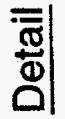
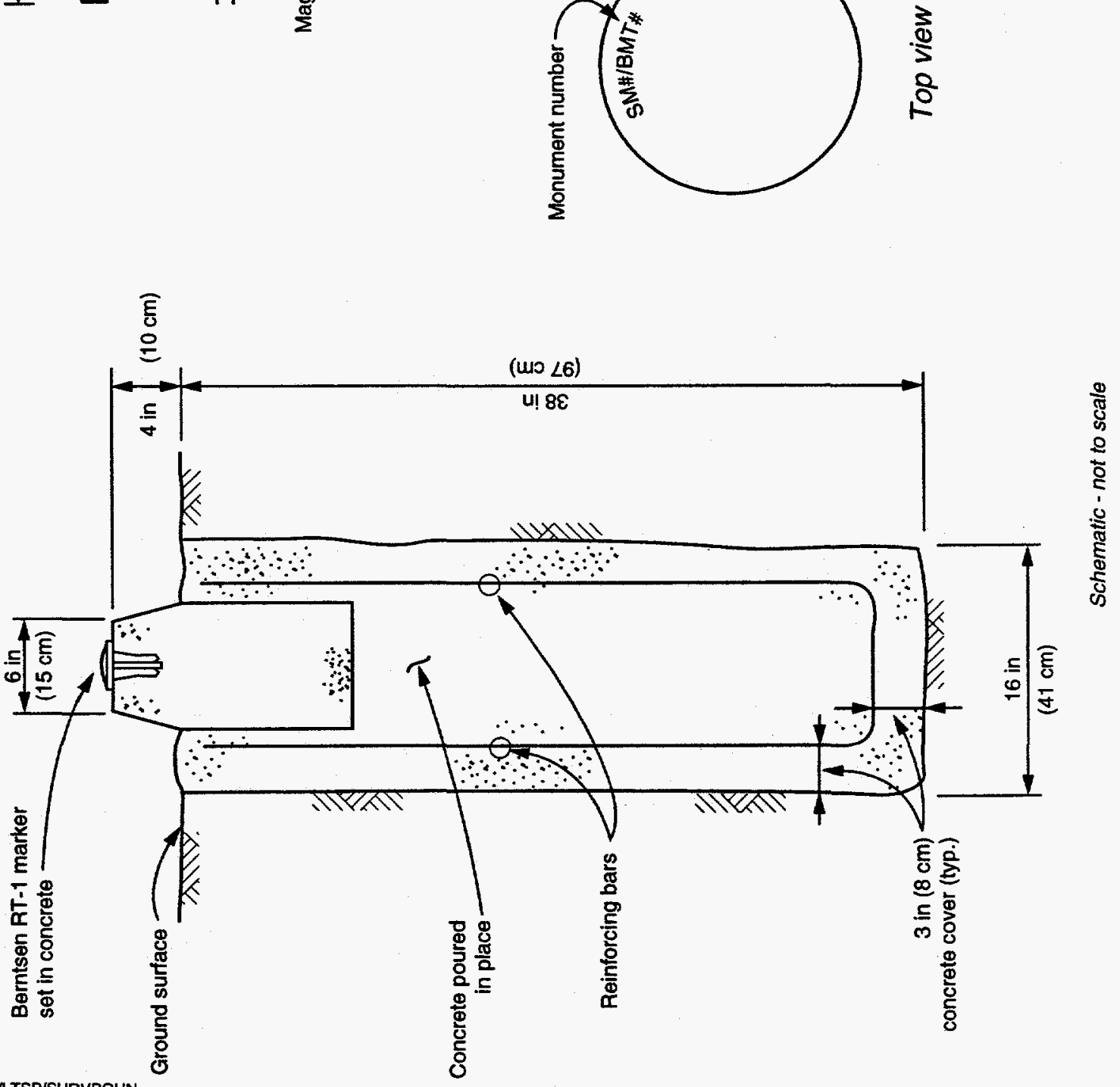

MAC: SITEIAMBLTSPISUAVBOUN 
Figure 4.2

Boundary Monument

Ambrosia Lake, New Mexico, Site

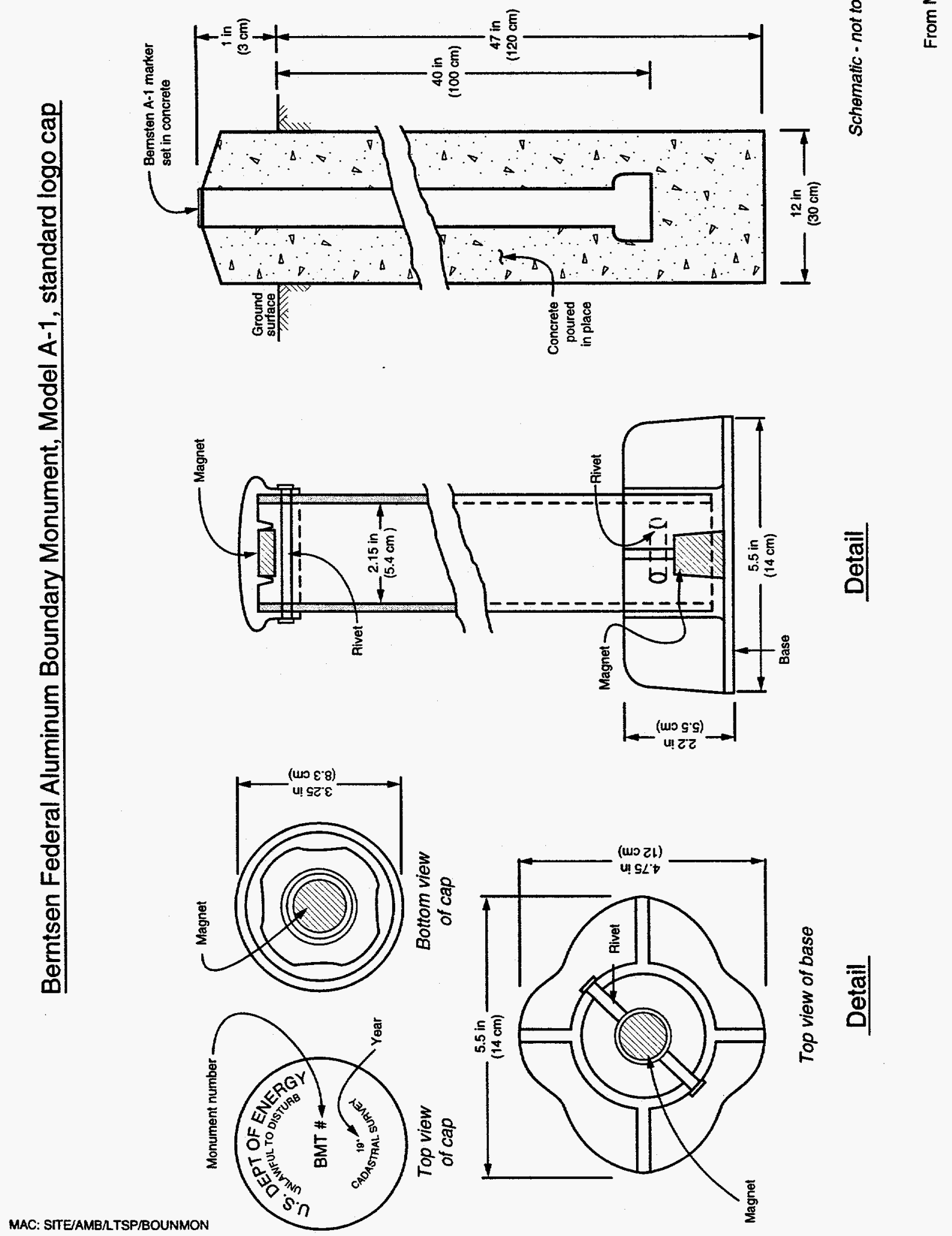




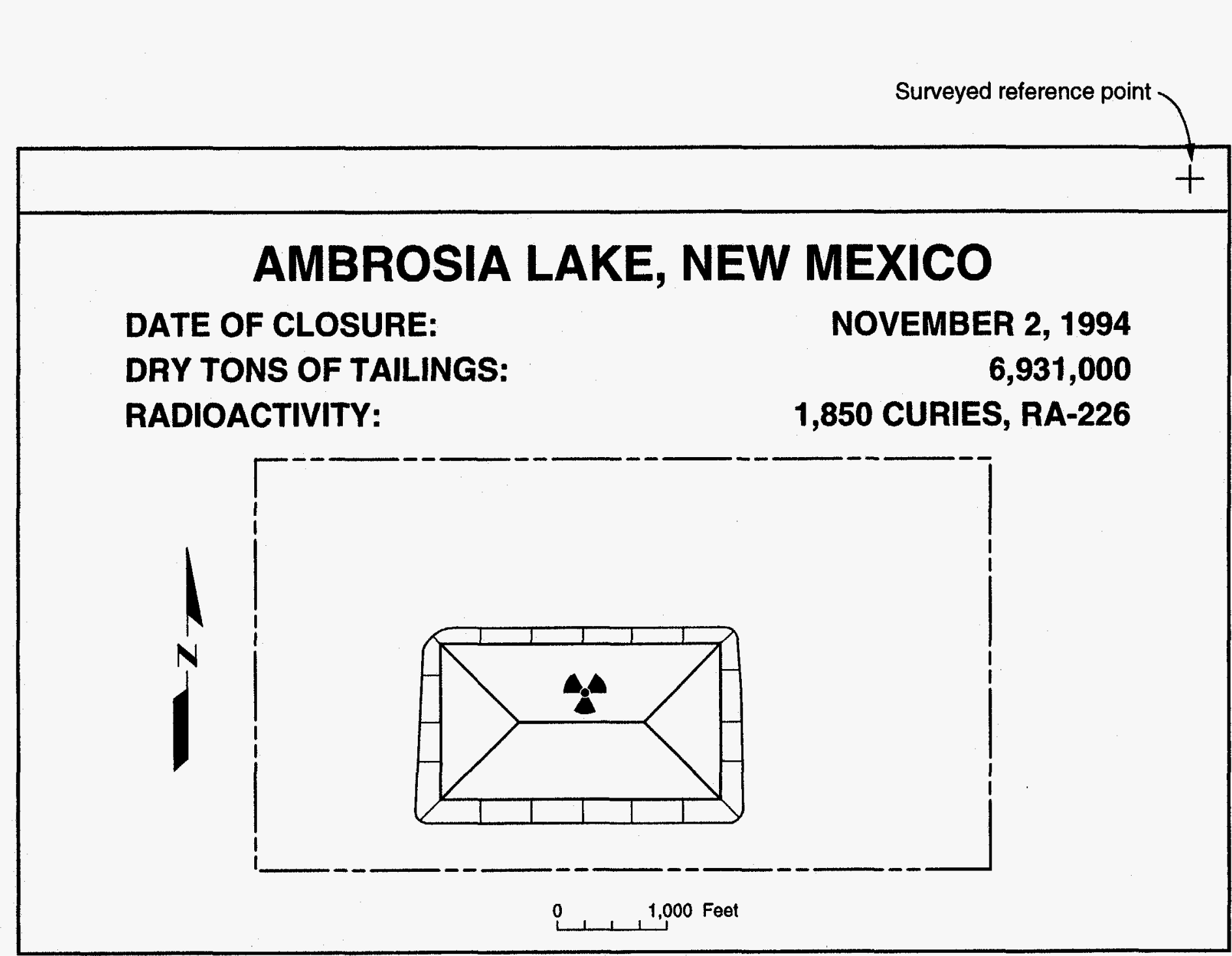




\section{Figure 4.4}

\section{Site Marker at Entrance}

\section{Ambrosia Lake, New Mexico, Site}

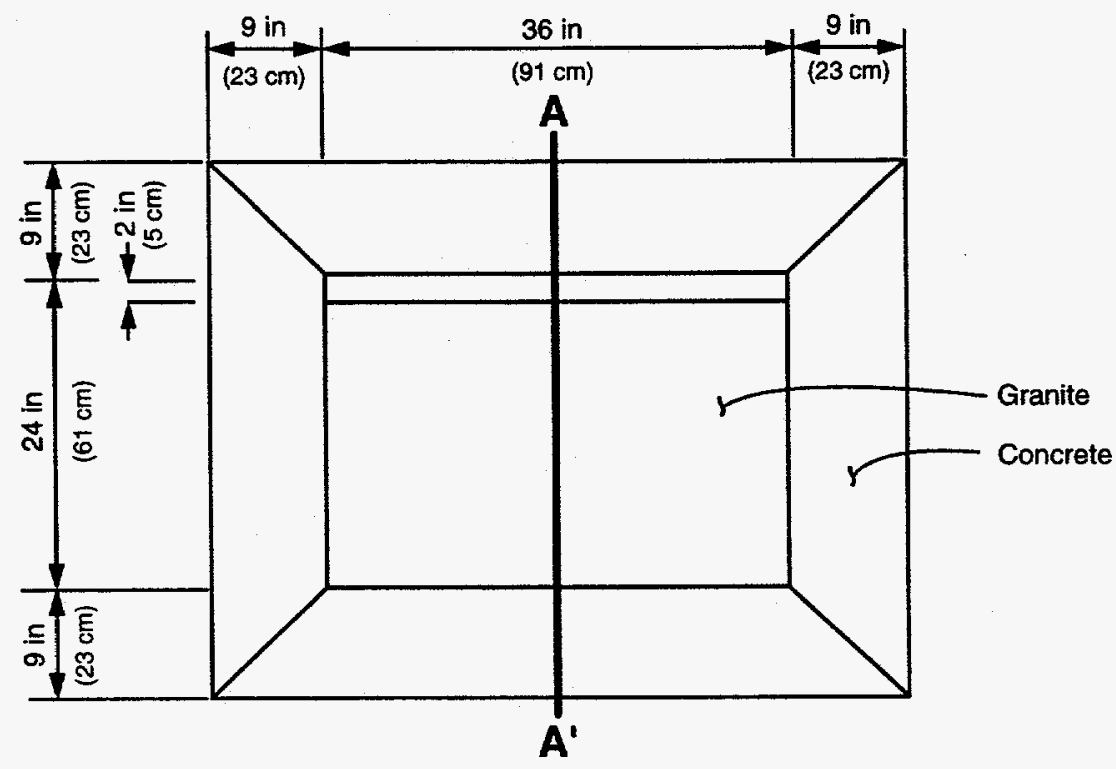

Plan view

Schematic - not to scale

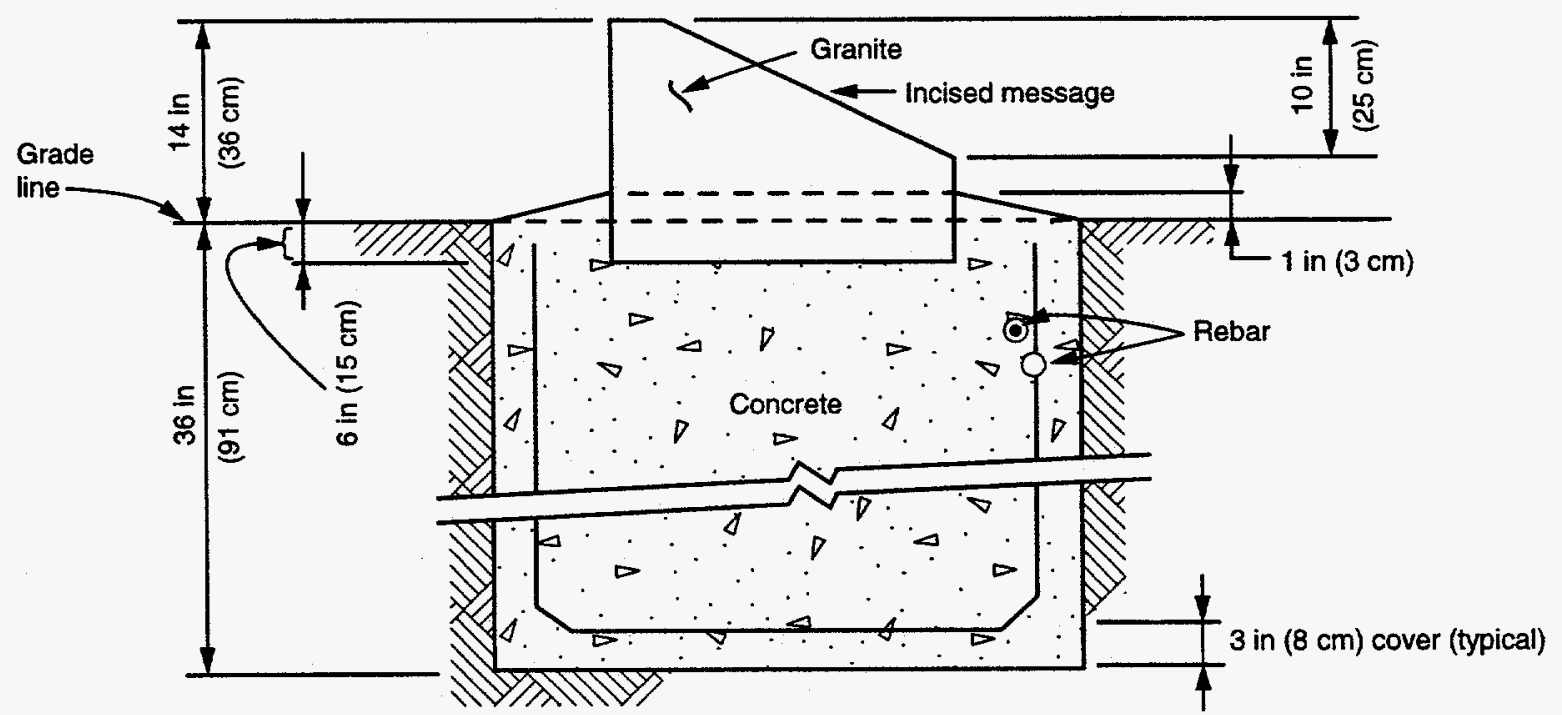

Section $A-A^{\prime}$

Schematic - not to scale

From MK-ES, 1992.

MAC: SITE/AMB/LTSP/SMK-1 
Figure 4.5

Site Marker at Disposal Cell Crest Ambrosia Lake, New Mexico, Site

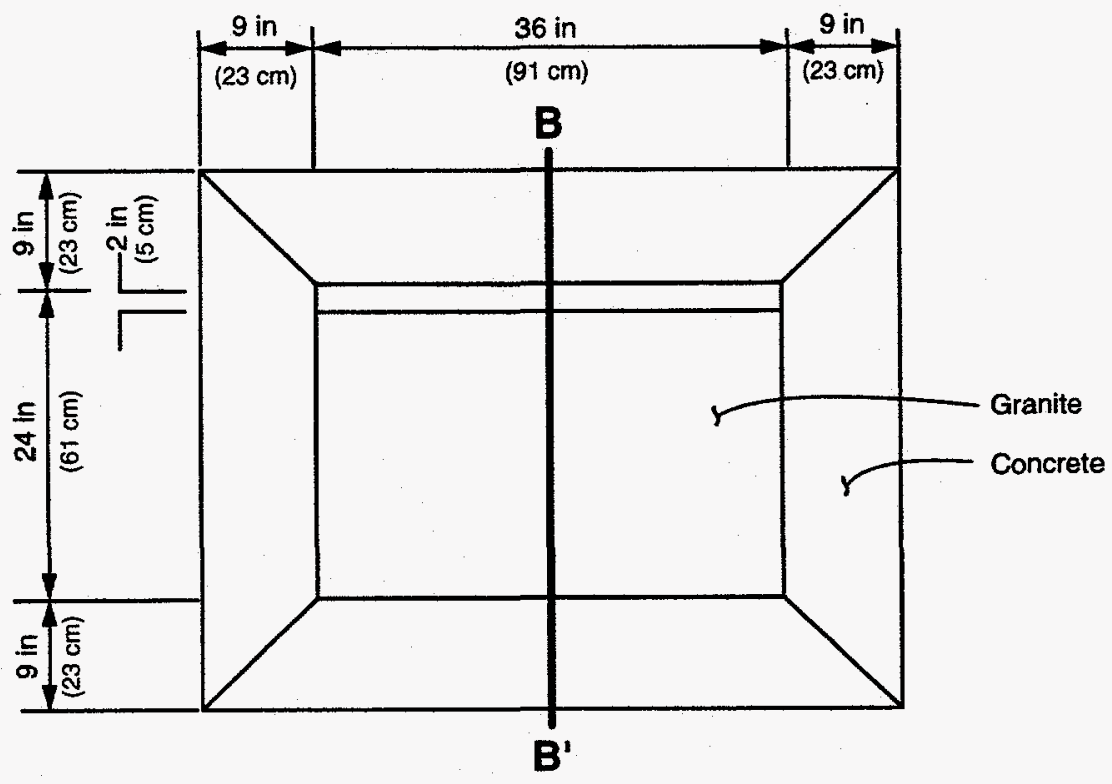

Plan view

Schematic - not to scale

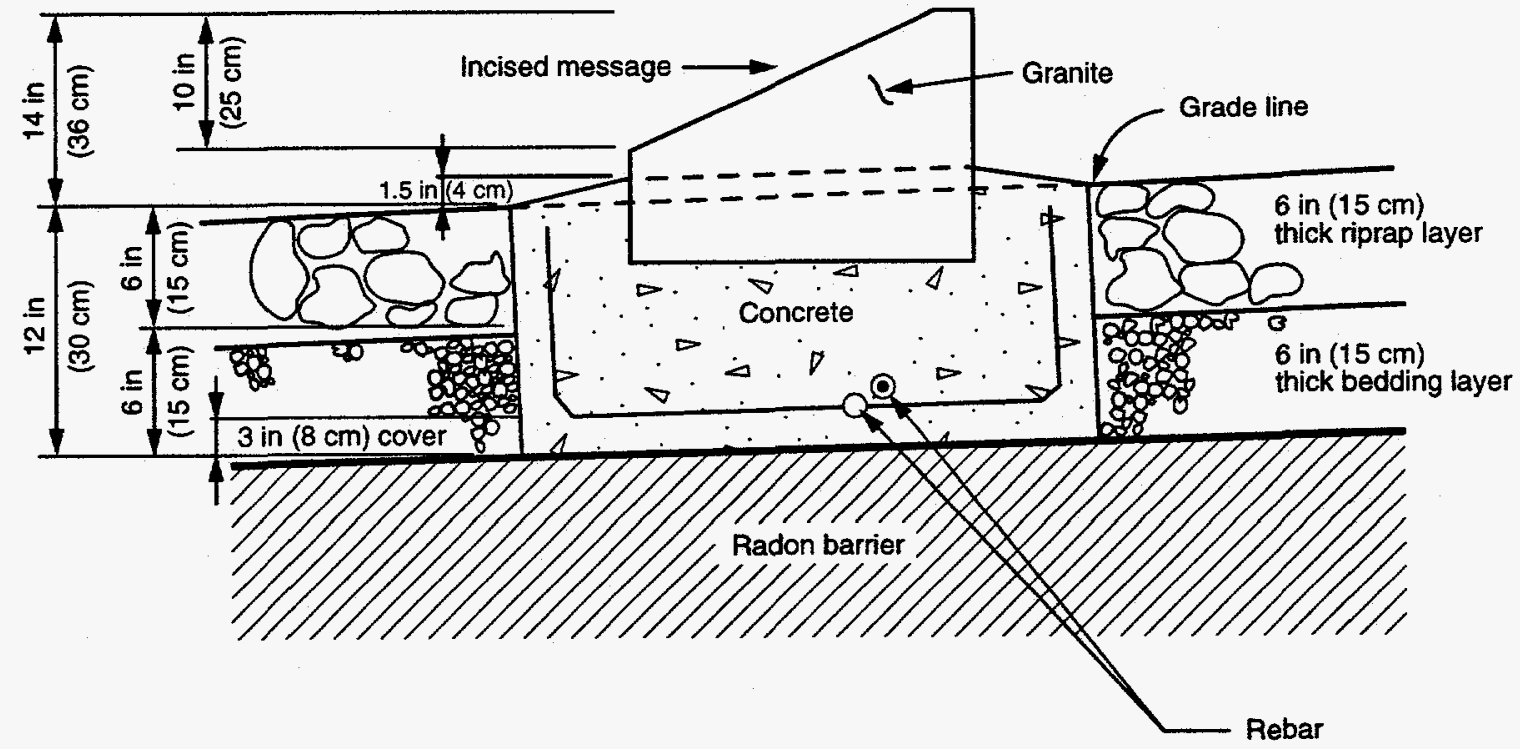

Section B - B'

Schematic - not to scale

From MK-ES, 1992.

MAC: SITEAMMBRTSP/SITEMARK 
the name of the disposal site, the international symbol indicating the presence of radioactive material, a notice that trespassing is forbidden on this federally owned site, and the 24-hour telephone number of the DOE Albuquerque Operations Office (Figure 4.6). In addition to the entrance sign, 70 warning signs mounted on steel posts are placed at approximately $200-\mathrm{ft}(60-\mathrm{m})$ intervals around the site perimeter (Plate 1). These perimeter signs display the international symbol indicating the presence of radioactive material and state that the disposal site is U.S. Government property, that it contains uranium mill tailings, and that trespassing is forbidden (Figure 4.7). The perimeter sign posts on the west side of the site between boundary monuments BMT-6 and BMT-7 also have mining restriction warning signs mounted directly below the perimeter signs. The mining restriction signs warn that no conventional mining is allowed within $400 \mathrm{ft}(120 \mathrm{~m}$ ) of the disposal cell (Figure 4.8).

The signs are constructed in accordance with the dimensions and specifications shown in Figures 4.6, 4.7, and 4.8, and mounted with the tops of the entrance and perimeter signs about $6 \mathrm{ft}(2 \mathrm{~m})$ above the ground surface. The sign posts are embedded in concrete to a depth of about $3 \mathrm{ft}(1 \mathrm{~m})$ below the ground surface.

\subsection{DISPLACEMENT MONUMENTS}

Eight displacement monuments are installed on the disposal cell to monitor the anticipated settlement of the tailings embankment during placement of contaminated materials and disposal cell cover (Plate 1). The displacement monuments were installed at various depths to the specifications shown in Figure 4.9. Displacement monuments DM-1 to DM-4 were installed on the compacted subgrade surface; DM-5 to DM-8 were installed on top of contaminated material. The displacement monuments will not be monitored during routine annual inspections. However, if there is a future need, they can be used to measure long-term settlement of the disposal cell. 


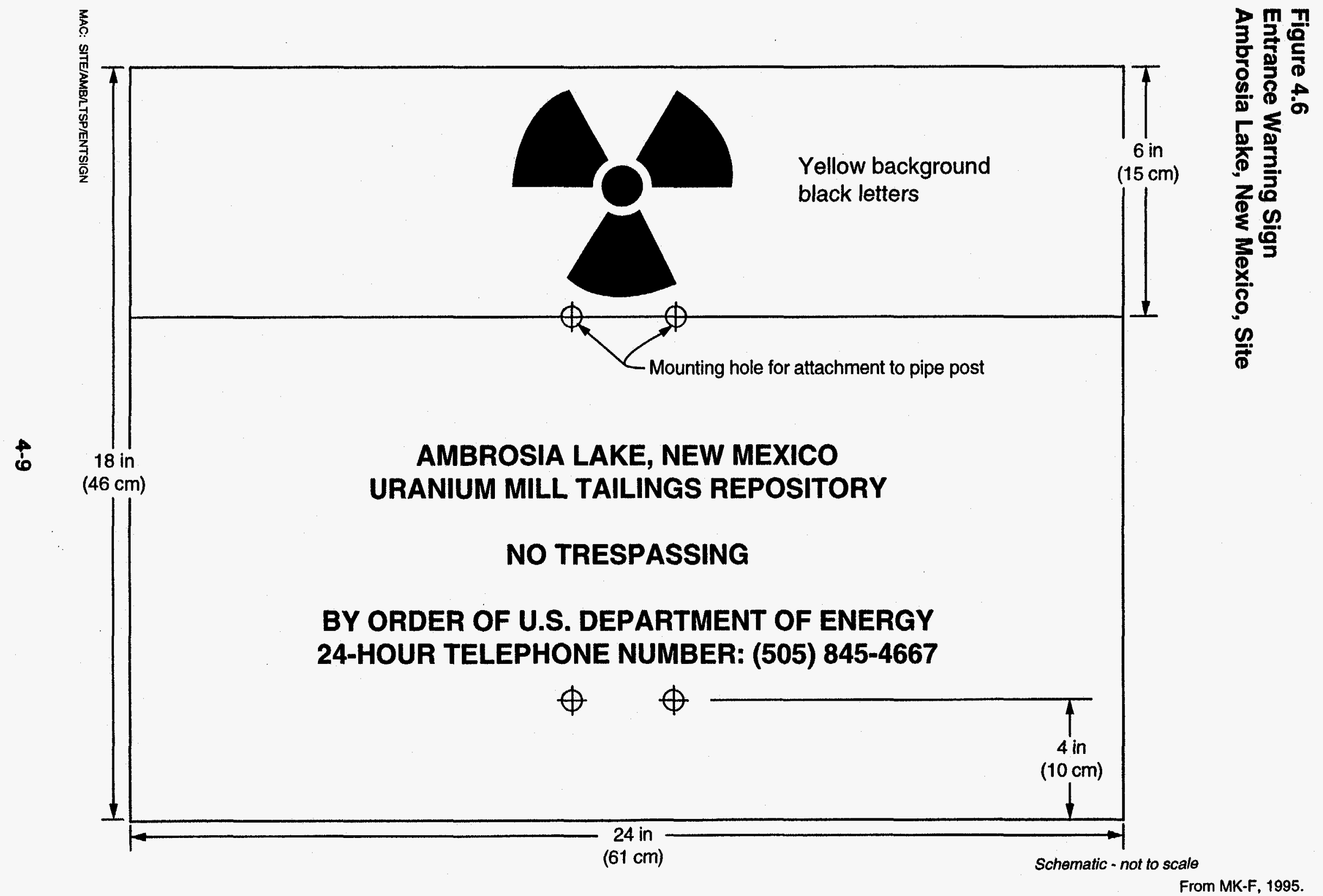




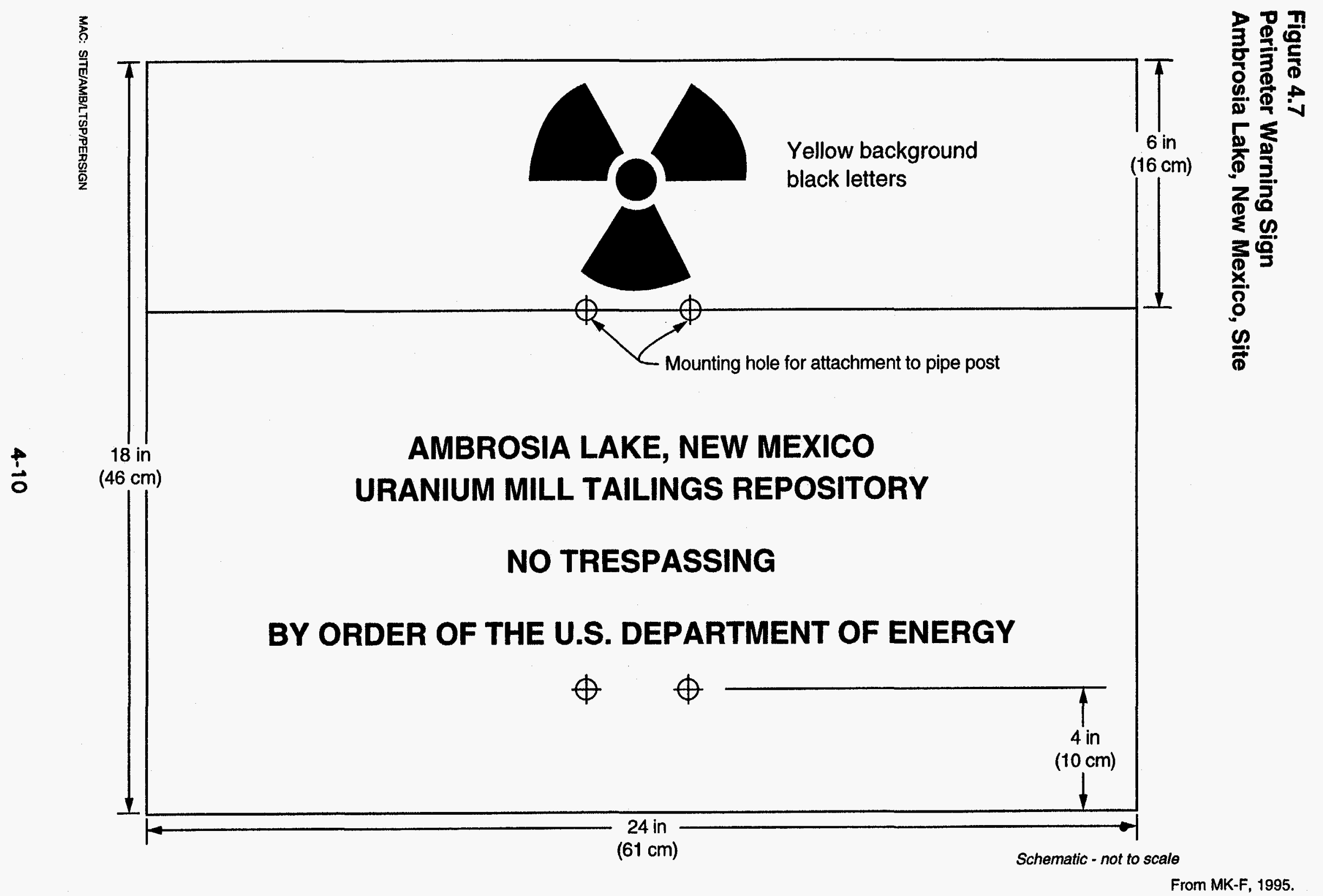




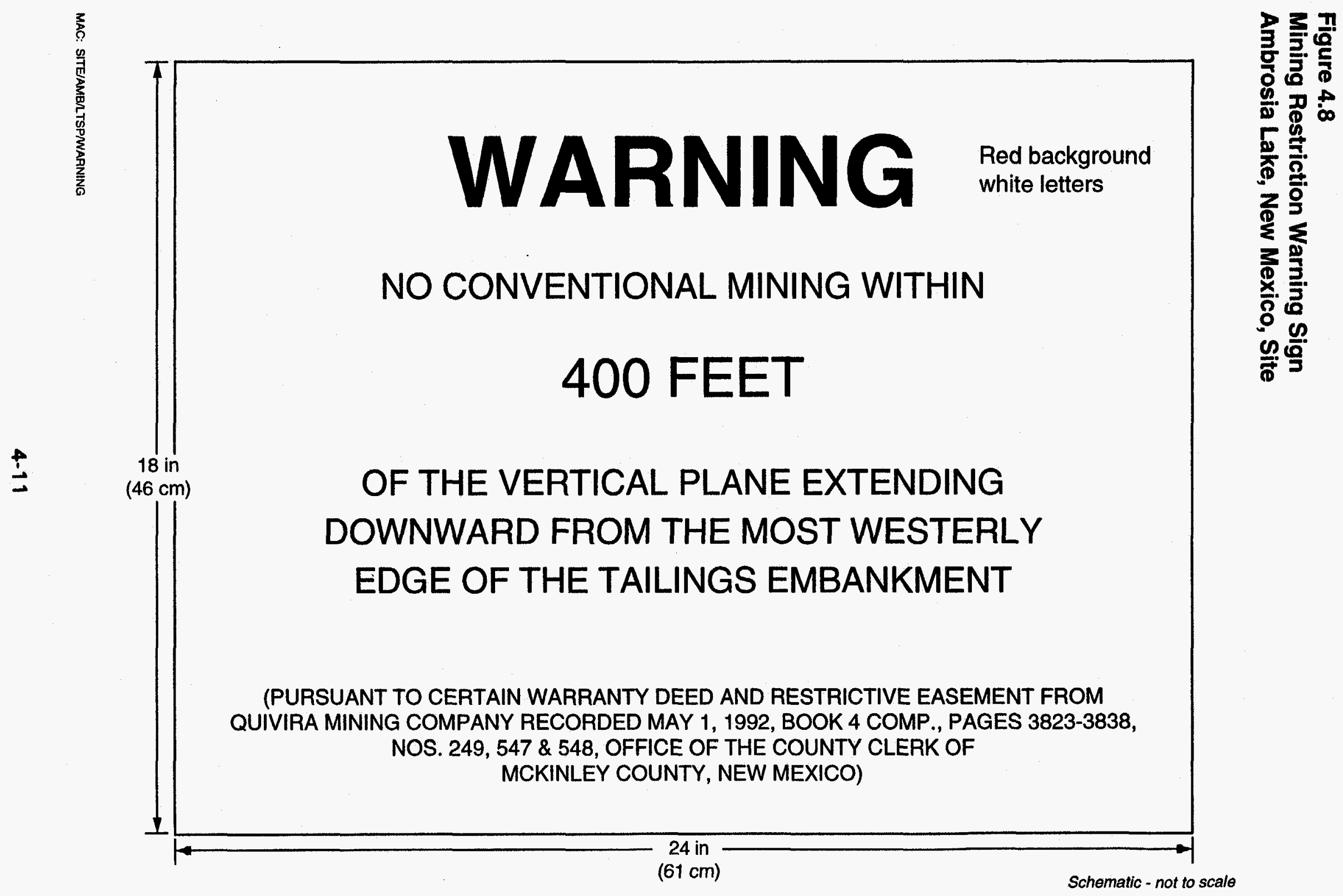

From MK-F, 1995. 
Figure 4.9

Displacement Monument

Ambrosia Lake, New Mexico, Site

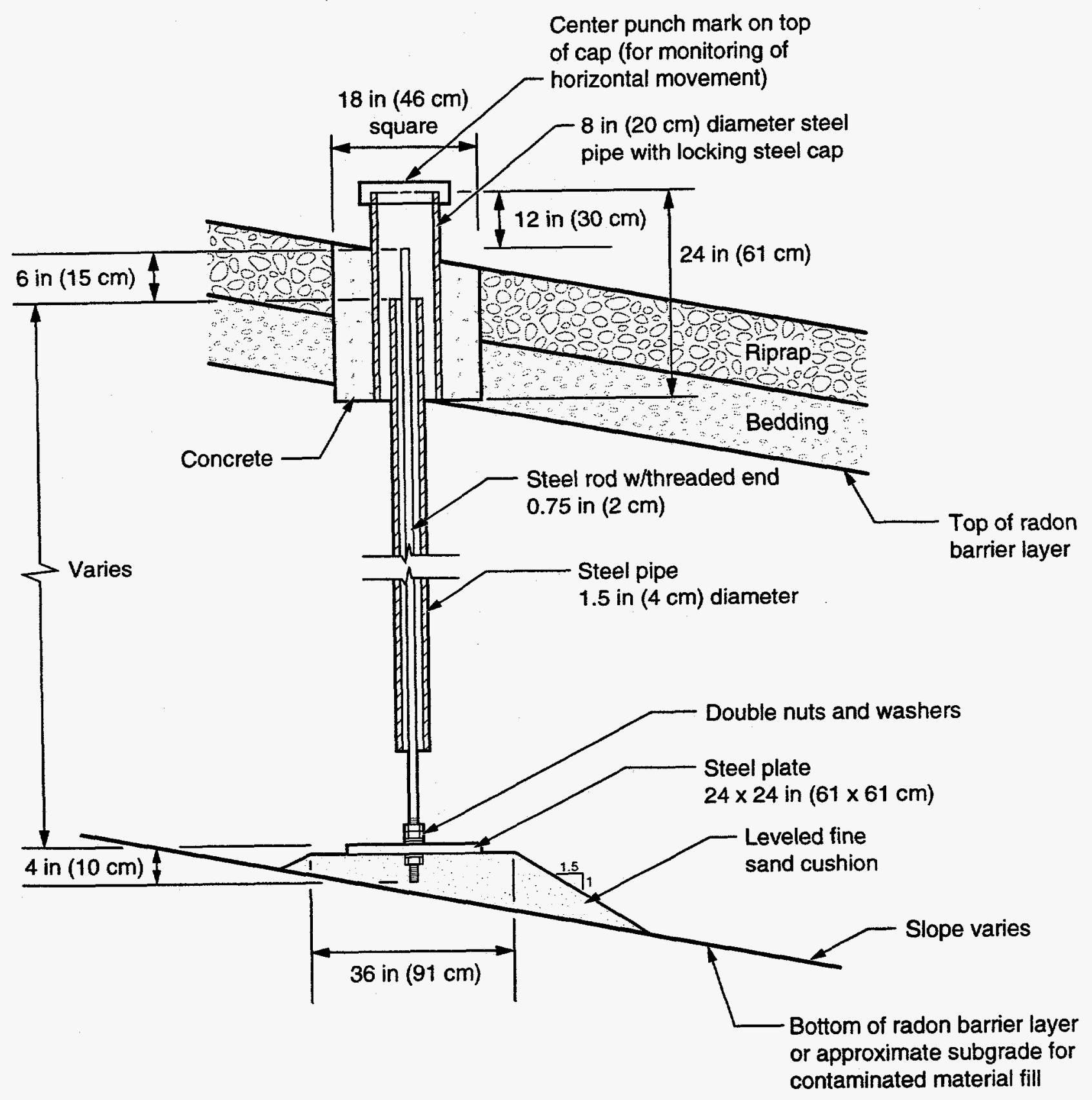

Typical detail-not to scale

From MK-F, 1995.

MAC: STIE/AMBRTSPIMONUMENT 


\subsection{GROUND WATER CHARACTERIZATION AND MONITORING}

The need for ground water monitoring at the Ambrosia Lake disposal site was evaluated in accordance with the NRC regulations in 10 CFR $\$ 40.27(b)(2)$, and long-term surveillance program guidelines (DOE, 1992a). The implementation guidance in Subpart C of $40 \mathrm{CFR}$ Part 192, as revised by 60 FR 2854, describes specific conditions for applying supplemental standards for ground water rather than meeting background levels or numerical standards. The DOE has determined that a program to monitor ground water is not required for the Ambrosia Lake site because ground water in the uppermost aquifer is of limited use, and a narrative supplemental standard has been applied to the site that does not include numerical concentration limits or a point of compliance. The limited use designation is appropriate because the uppermost aquifer does not represent a ground water resource since the aquifer will not sustain a yield of 150 gallons (gal) (570 liters [L]) per day to wells.

\subsection{GROUND WATER CHARACTERIZATION}

Ground water at the Ambrosia Lake site is influenced by climate, human activities, and surface and subsurface features. Though the focus of this section is a description of the hydrostratigraphic units that may be affected by the disposal cell, information regarding the physical and environmental conditions is included. Most of the information presented here is described in more detail in the Ambrosia Lake remedial action plan (DOE, 1991) and the site observational work plan (DOE, 1995). Some data has been collected since the completion of the site observational work plan and is also reported in this LTSP.

\subsubsection{Climate and surface features}

A general description of the site climate and surface features is presented in Section 2.2. The potential for recharge of ground water by infiltration of precipitation is estimated as the precipitation less the evaporation and transpiration of vegetation. Reported evaporation is about six times the reported precipitation (Appendix D of DOE, 1991). The majority of the precipitation occurs during the summer when evaporation and transpiration potentials are high and the soil moisture content is low thus limiting significant infiltration. As a result, recharge to ground water may only occur in the vicinity of surface depressions that are able to trap runoff from a wide area. However, these areas are localized and are not expected to contribute significantly to ground water recharge in the vicinity of the Ambrosia Lake disposal site.

\subsubsection{Human activities}

The Ambrosia Lake area has served as a mining and milling center from the mid1950 's to the early 1980's, with limited activities extending into the 1990's. Dewatering of subsurface strata to facilitate the construction of vertical mine shafts, followed by horizontal mining to extract uranium ore, affected the preexisting ground water in several subsurface geologic rock units in the area. The 
ground water pumped from the mines was used for milling processes or was discharged to retention ponds. The influences from nearby mine and mill operations on ground water in the Ambrosia Lake area are discussed in Sections 5.1.3, 5.1.4, and 5.1.5.

Waste water was produced from the former Phillips Mill at a rate of 1 to 5 tons (0.9 to 4.5 metric tons) for every ton of ore processed (Merritt, 1971); therefore, 3 to 15 million tons (2.7 to 13.6 million metric tons) of waste water were produced during the 5 years of ore milling. This is equivalent to between 2200 to 11,000 ac-ft $\left(2.7\right.$ to 14 million $\left.\mathrm{m}^{3}\right)$ of waste water. Waste water, with the tailings, was disposed of in the tailings pile and also collected in two former holding ponds located east of the tailings pile in the southeast corner quarter of Section 28; some waste water was possibly discharged to a canal that led to a separate holding pond called the Voght Tank, formerly located in Section 34; and some waste water also was discharged to two holding ponds near the southeast corner of the tailings pile in Section 33 (Figure 2.2). The influences of these waste water discharges on ground water in the immediate vicinity of the disposal site are discussed in Sections 5.1.3, 5.1.4, and 5.1.5.

The ion-exchange process used at the Ambrosia Lake site probably contributed little if any contamination to the site. Water that was passed through the ionexchange columns was returned to its source (the mines), and not discharged to the land surface. Water applied to the heap leach piles was collected with a drain system for recovery of uranium using the ion-exchange columns.

Water supplies associated with mill cleanup activities were from wells completed in the uranium ore zone (the Westwater Canyon Member of the Morrison Formation) and deeper hydrogeologic units. Domestic and stock wells in the Ambrosia Lake area are also completed in the ore zone or deeper units and obtain water at depths from $300 \mathrm{ft}(90 \mathrm{~m})$ to greater than $800 \mathrm{ft}(240 \mathrm{~m})$. No wells are completed in any of the shallower zones (alluvium and Tres Hermanos Sandstones) within at least a $5-\mathrm{mi}(8-\mathrm{km})$ radius of the site, with the exception of monitor wells installed by the DOE (DOE, 1991). These water supply wells have no impact on the ground water in the uppermost aquifer beneath the disposal site.

The nearest public water supply is operated by the town of San Mateo, $10 \mathrm{mi}$ $(16 \mathrm{~km})$ southeast of the Ambrosia Lake site. The water for San Mateo is derived from the Point Lookout Sandstone (Brod, 1979), which is stratigraphically higher than, and not connected with, any of the geologic units at the Ambrosia Lake site, and, therefore, is not impacted by ground water beneath the disposal site.

\subsubsection{Hydrostratigraphy}

A generalized, regional geologic cross section illustrating the dip, relative depths, and relative thickness of each unit described below is shown in Figure 5.1. 


\section{SW}

Ground water recharge in outcrop areas
Qulvira

pile -

pile 7
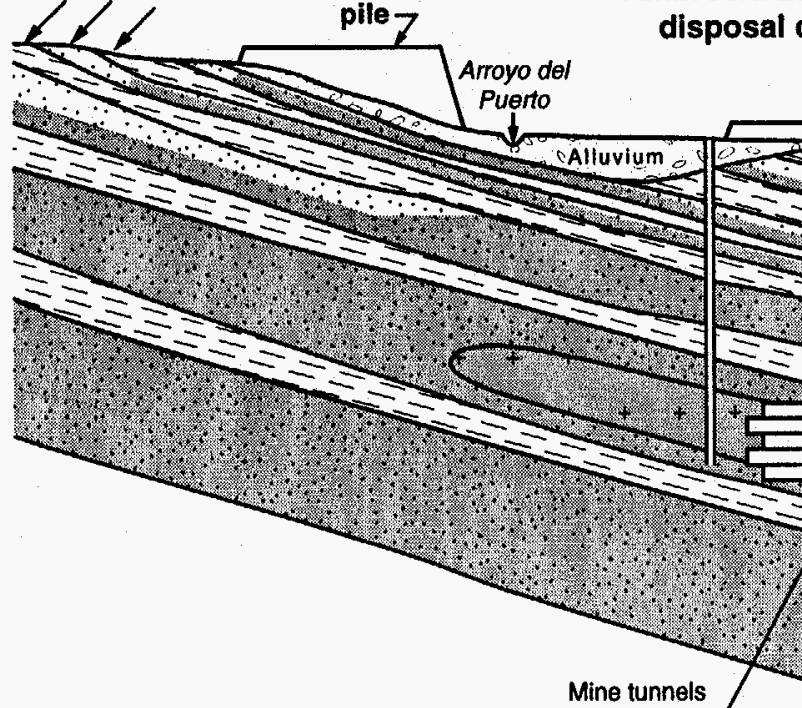

and difits -

Hydrogeologlc characteristics

\subsection{Alluvium}

Aquitard, confining unit

2.7202 Saturated aquifer

$\therefore \because$ Unsaturated aquifer

++ Ore body

$x \quad$ Weathered Mancos Shale

II Exploratory boreholes
2007

3. 응

등 형

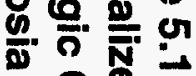

용

w

बิ

$z \infty \frac{0}{0}$

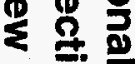

з응

จ

ํ.

ถั

䎹 
The soil and rock units underlying the Ambrosia Lake site can be divided into four hydrostratigraphic units. These units, in descending order, include:

1. The alluvium, weathered portions of the Mancos Shale, and the Tres Hermanos- $C_{1}$ and $-C_{2}$ Sandstone units combined, designated as the uppermost aquifer (DOE, 1991)

\section{The Tres Hermanos-B and -A Sandstone units}

3. The Dakota Sandstone

\section{The Westwater Canyon Member of the Morrison Formation}

At the Ambrosia Lake site, Quaternary alluvium lies on top of an erosional surface of weathered Cretaceous Mancos Shale. The alluvium and weathered Mancos Shale are hydraulically interconnected and appear to behave as a single hydrologic unit. Underlying the alluvium/weathered Mancos Shale is the unweathered, lower portion of the Mancos Shale Formation that contains four silty sandstone interbeds, known as the Tres Hermanos- $C_{1}$ (upper), and $-C_{2}$ (lower), -B, and -A Sandstone units. Other hydrostratigraphic units beneath the site that may be water-bearing include (in descending order) the Cretaceous Dakota Formation and the Jurassic Westwater Canyon Member of the Morrison Formation. Below the Westwater Canyon Member is more than $150 \mathrm{ft}(46 \mathrm{~m})$ of shale, siltstone, and sandstone of the Recapture Member of the Morrison Formation, which was not disturbed during uranium mining and acts as a confining layer.

With the exception of the alluvium, the regional dip of the geologic units beneath the site is toward the northeast at approximately 2 degrees. The alluvium has been deposited nearly horizontally on top of the Mancos Shale.

Figure 5.2 shows the location of a cross section constructed using information from monitor wells installed as part of the UMTRA Project. The cross section is shown in Figure 5.3, and illustrates the configuration of the shallow hydrostratigraphic units that lie beneath Ambrosia Lake site. Figure 5.4 shows the relationship between the geologic and hydrostratigraphic units. A summary of the hydraulic properties of these hydrostratigaphic units is presented in Table 5.1 .

\section{Alluvium/weathered Mancos Shale and Tres Hermanos-C Sandstone}

The alluvium/weathered Mancos Shale unit underlying the Ambrosia Lake site extends to a depth of approximately 15 to $75 \mathrm{ft}(5$ to $23 \mathrm{~m})$ below ground surface. The alluvium consists of a mixture of gravels, sands, silts, and clays. The alluvium is deposited on top of an erosional surface of weathered Mancos Shale. Underlying the weathered Mancos Shale is the unweathered, lower portion of the Mancos Shale which contains four silty sandstone interbeds, 
Figure 5.2

\section{Location of Monitor Wells and Former/Current Site Features} Ambrosia Lake, New Mexico, Site

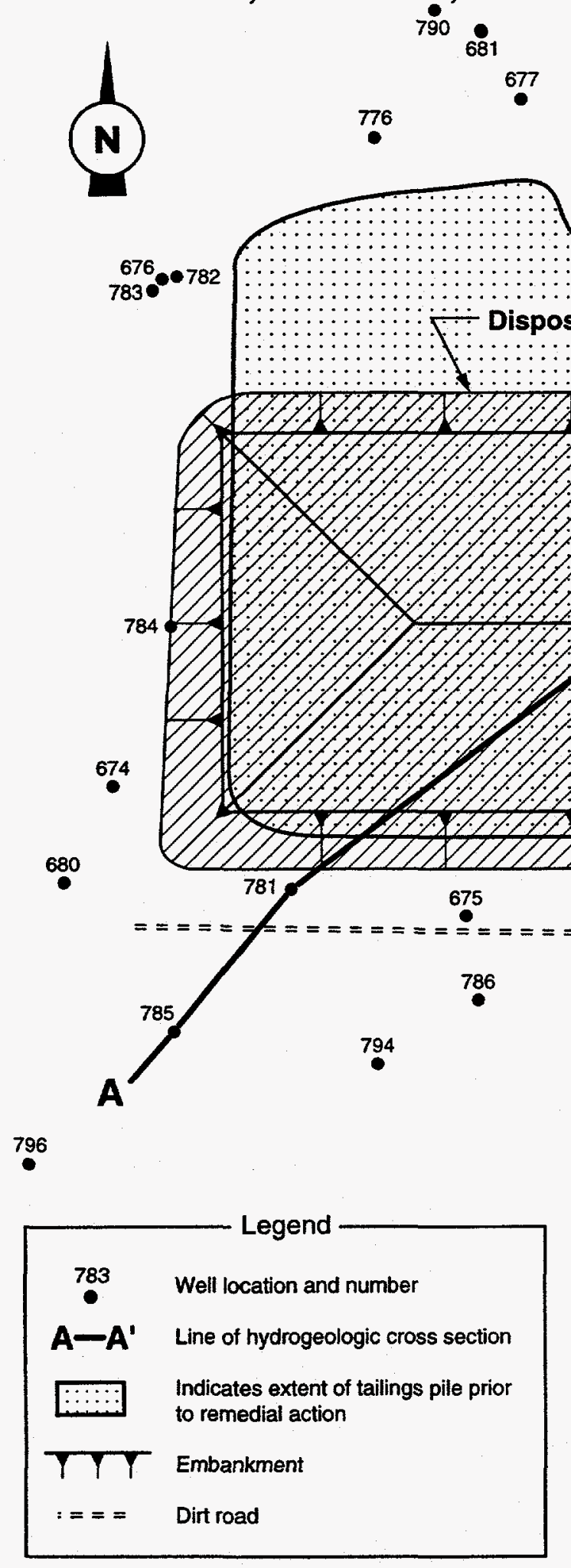

Ann Lee mine no. 1

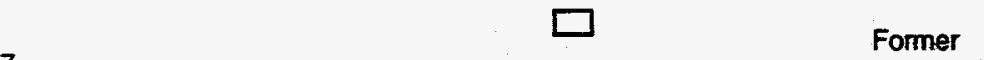


Figure 5.3

Hydrogeologic Cross Section A-A', Ambrosia Lake, New Mexico, Site

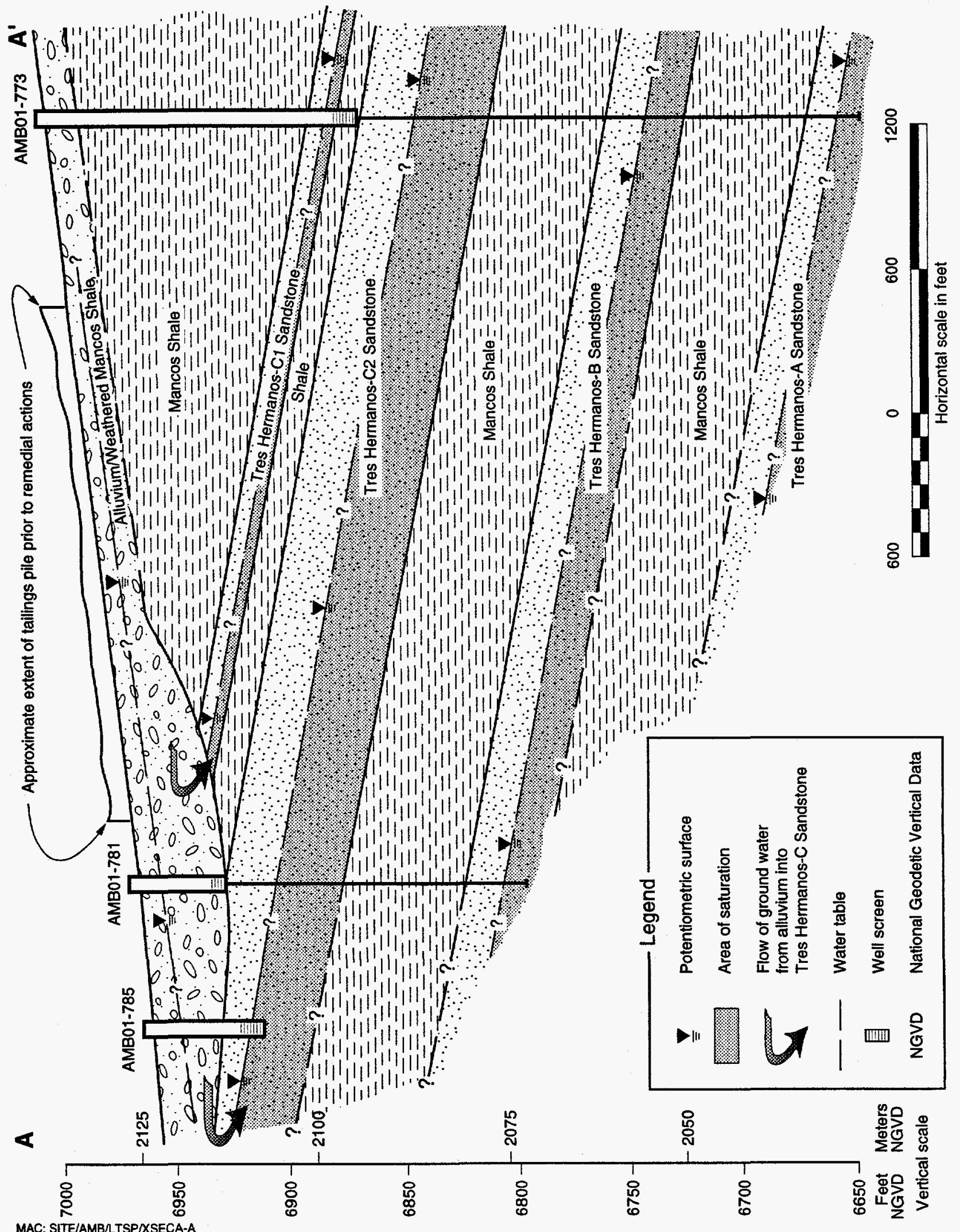


Figure 5.4

Relationship Between Geologic and Hydrostratigraphic Units Ambrosia Lake, New Mexico, Site

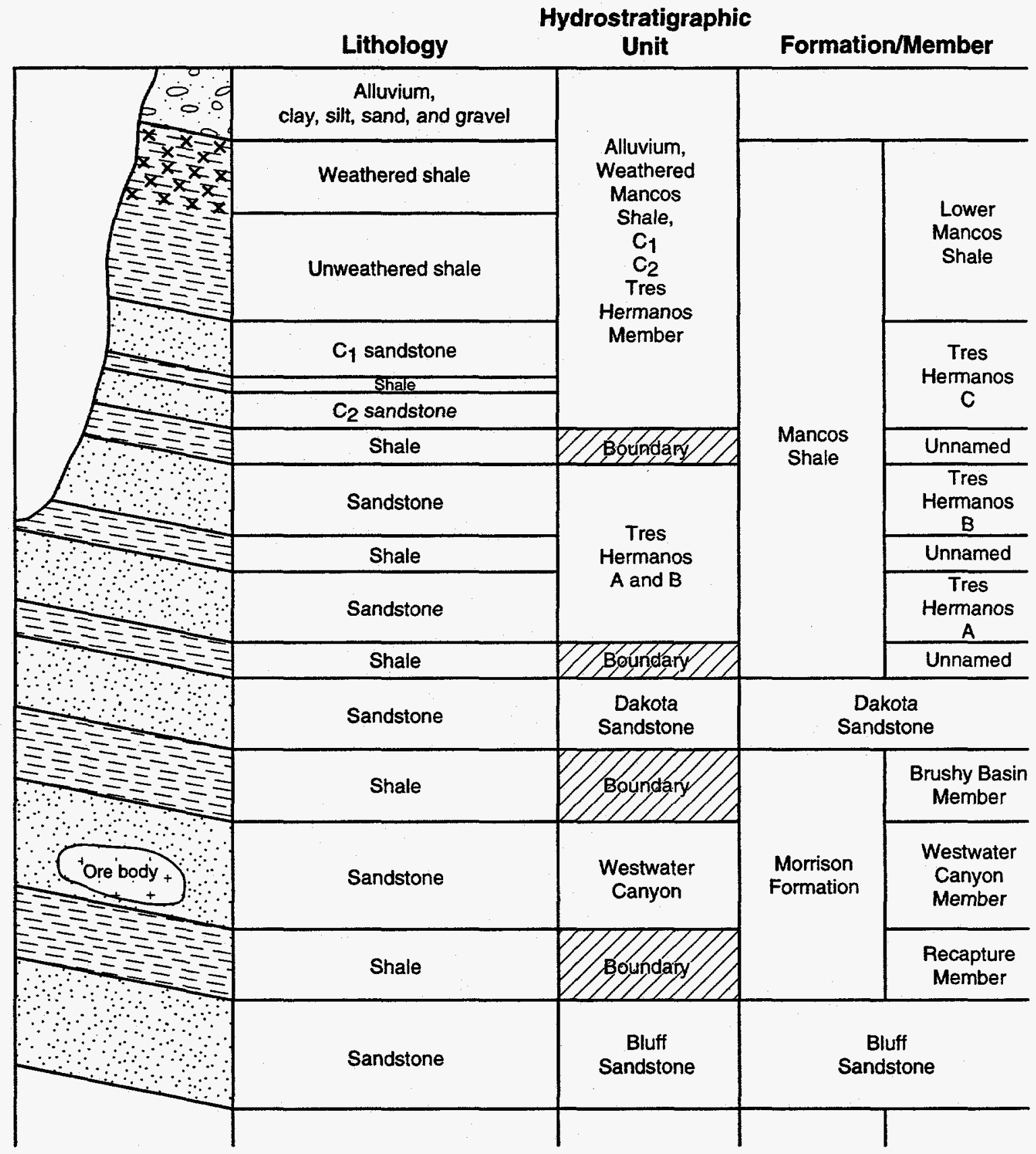




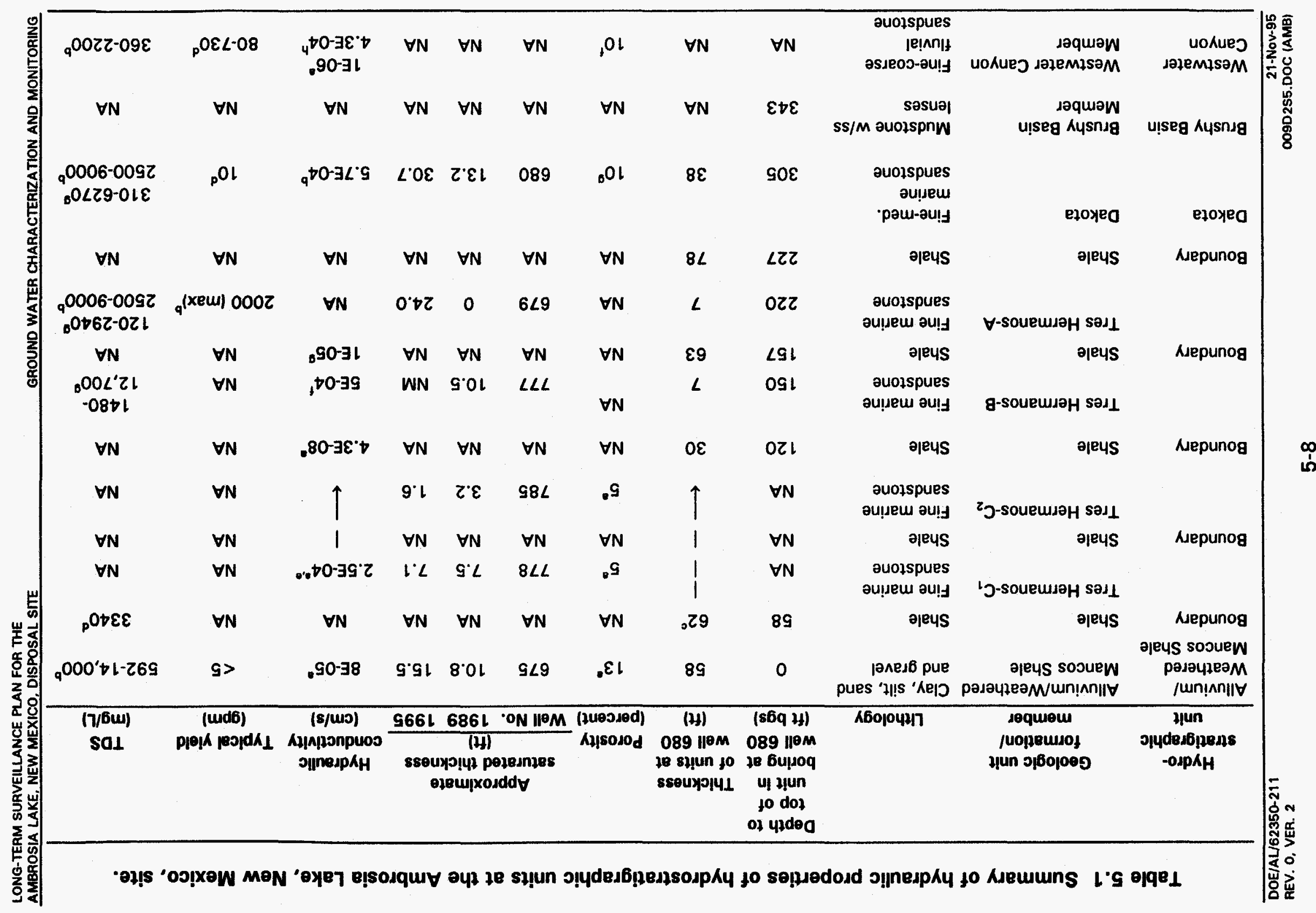




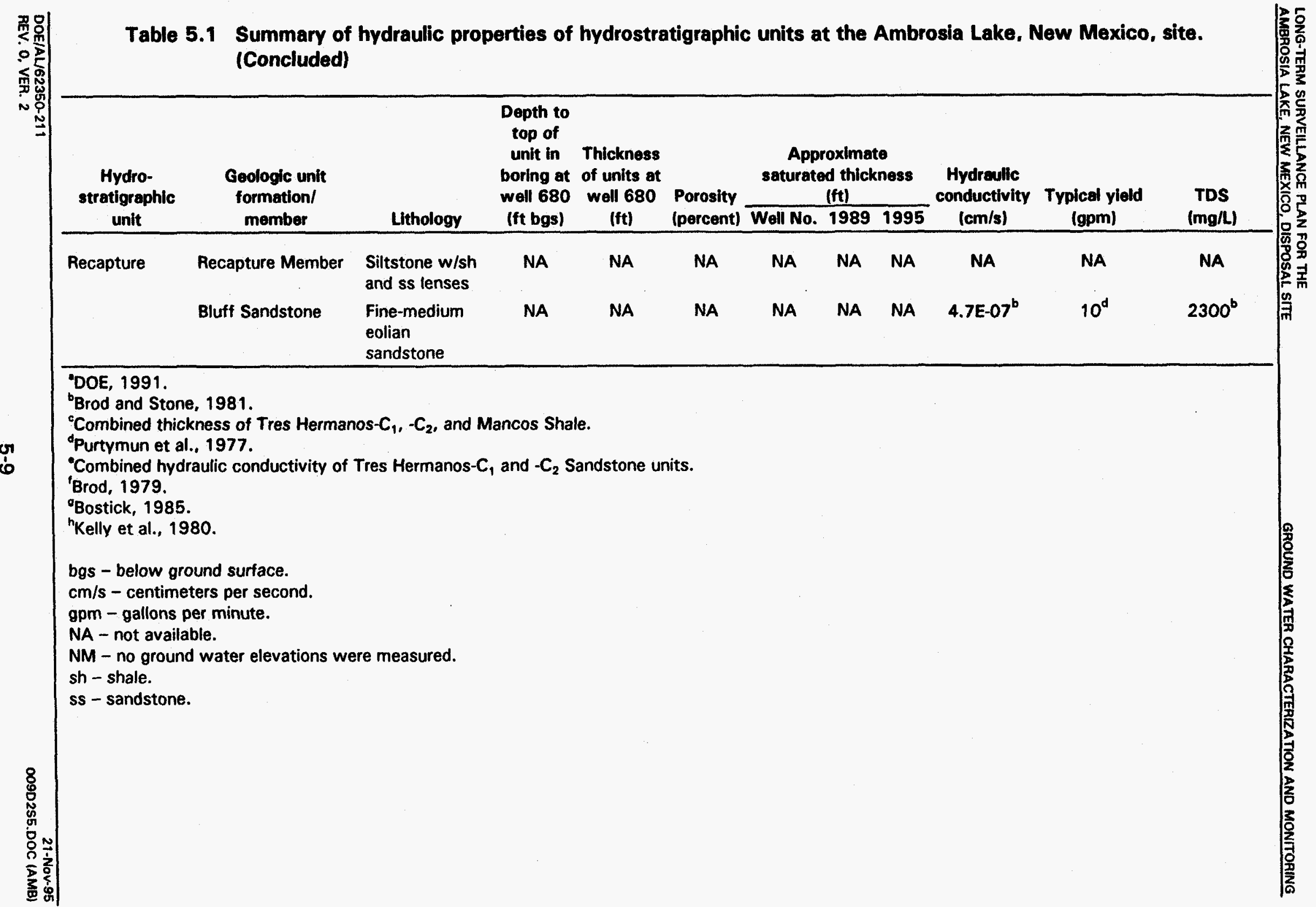


known as the Tres Hermanos- $C_{1}$ (upper), and $-C_{2}$ (lower), $-B$, and $-A$ Sandstone units. The Tres Hermanos- $C_{1}$ and $-C_{2}$ Sandstone units are separated by a 10- to 15-ft (3- to 5-m) -thick interbed of shale and subcrop into the alluvium beneath the western side of the site (Figures 5.1 and 5.3). The saturated portions of the alluvium/weathered Mancos Shale unit and the Tres Hermanos- $C_{1}$ and $-C_{2}$ Sandstone units comprise the uppermost aquifer. Water level observations collected in 1995 indicate that the maximum saturated thickness of any portion of this aquifer is about $25 \mathrm{ft}(8 \mathrm{~m})$.

The majority of ground water present in the alluvium/weathered Mancos Shale and the Tres Hermanos-C Sandstone units at the Ambrosia Lake site is most likely a result of past uranium mining and milling activities in the area. During the period of the mill's operation, the discharge of ground water pumped from the Ann Lee Mine, as part of the mine dewatering process, and subsequent infiltration of water from an unlined mill process (makeup) water pond infiltrated into the underlying soil and bedrock including the alluvium/weathered Mancos Shale unit. Ground water to the north of the former tailings pile in the alluvium/weathered Mancos Shale unit appears to flow to the southwest under the site on top of the unweathered Mancos Shale (Figure 5.3). The ground water flows into the Tres Hermanos $-C_{1}$ and $-C_{2}$ Sandstone units where they subcrop into the overlying alluvium/weathered Mancos Shale unit. Ground water within both the upper and lower Tres-Hermanos-C sandstone units flows to the northeast in the direction of the regional dip as shown in Figure 5.3 (Brod and Stone, 1981).

Water level measurements collected in 1995 indicate that perched ground water occurs in the alluvium/weathered Mancos Shale at depths from 15 to $45 \mathrm{ft}$ (5 to $14 \mathrm{~m}$ ) below ground level at the site. During the period of investigation, the alluvium/weathered Mancos Shale unit was saturated below and directly south and west of the former tailings pile. Little or no ground water was encountered further to the south and west of the site because the Tres Hermanos-C Sandstone units intercept the flow in the alluvium/weathered Mancos Shale unit. Hydrographs of selected water level data collected from monitor wells completed in the alluvium/weathered Mancos Shale unit (AMB01-0674, -0675, $-0781,-0793$ ) from 1985 to 1995 are presented in Figure 5.5. Water levels have generally decreased in well 0674 since 1988, and in well 793 since 1993. Water levels have remained relatively constant in well 781 since 1986. However, recent water level rises have occurred in well 0675 which may be the result of toe drain runoff from the recently completed disposal cell. Ground water in the alluvium/weathered Mancos Shale unit flows along the southwestwardly sloping contact of the Mancos Shale under a hydraulic gradient estimated to be 0.025 from observations made in 1995 (Figure 5.6). The average hydraulic conductivity in the alluvium/weathered Mancos Shale unit is approximately $3 \times 10^{-4} \mathrm{~cm}$ per second $(0.9 \mathrm{ft}$ per day) and the average linear ground water velocity is approximately $7 \times 10^{-5} \mathrm{~cm}$ per second $(0.2 \mathrm{ft}$ per day) (DOE, 1991). Ground water is present in the alluvium several thousand feet southwest of the site. This ground water is associated with mine dewatering discharges into the Arroyo del Puerto, which is topographically much lower and 
Figure 5.5

Hydrograph Showing Ground Water Elevation Trends in Monitor Wells Completed in the Alluvium/Weathered Mancos Shale Hydrostratigraphic Unit Ambrosia Lake, New Mexico, Site

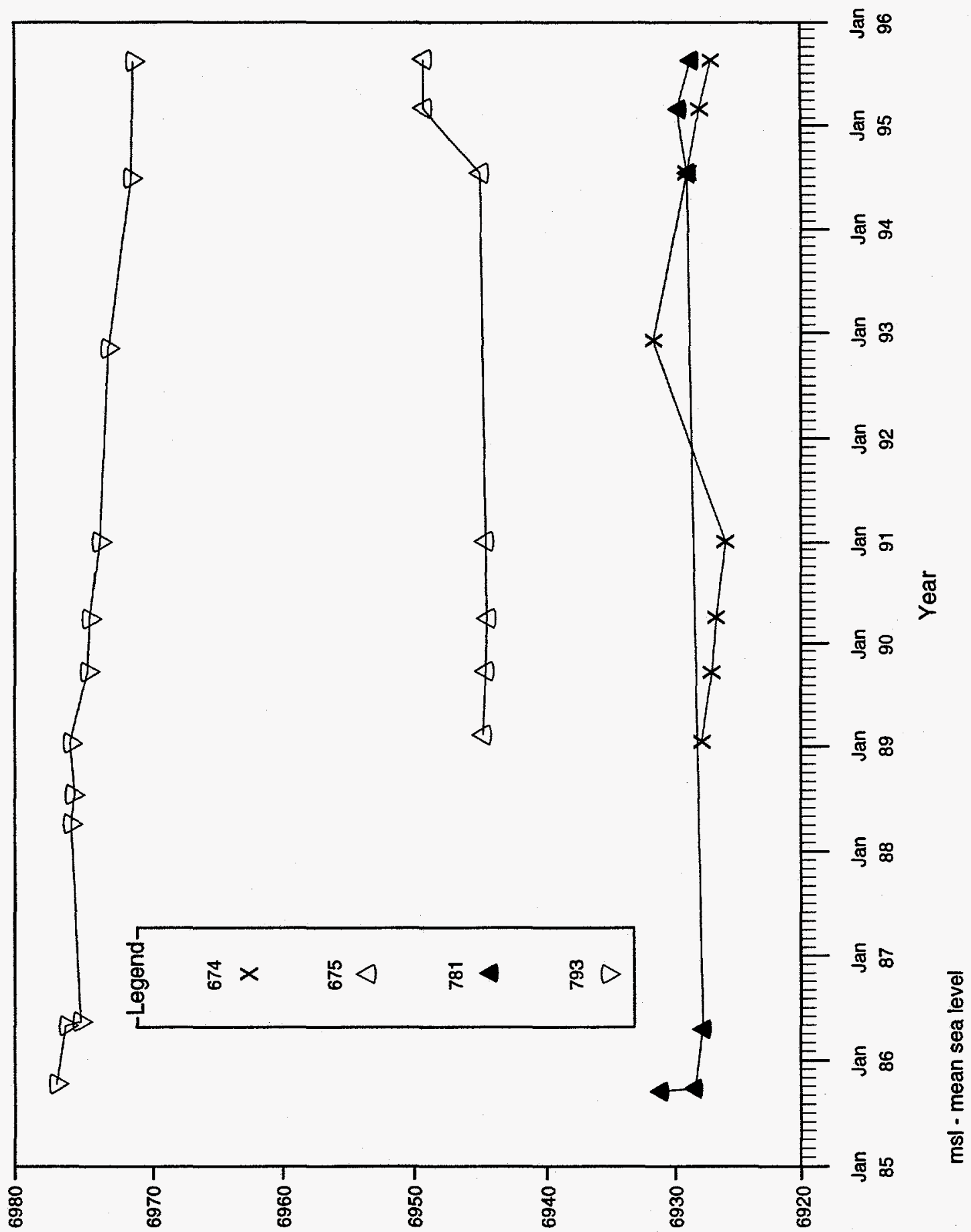

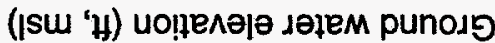


Figure 5.6

Ground Water Surface Map for Alluvium/Weathered Mancos Shale

Ambrosia Lake, New Mexico, Site

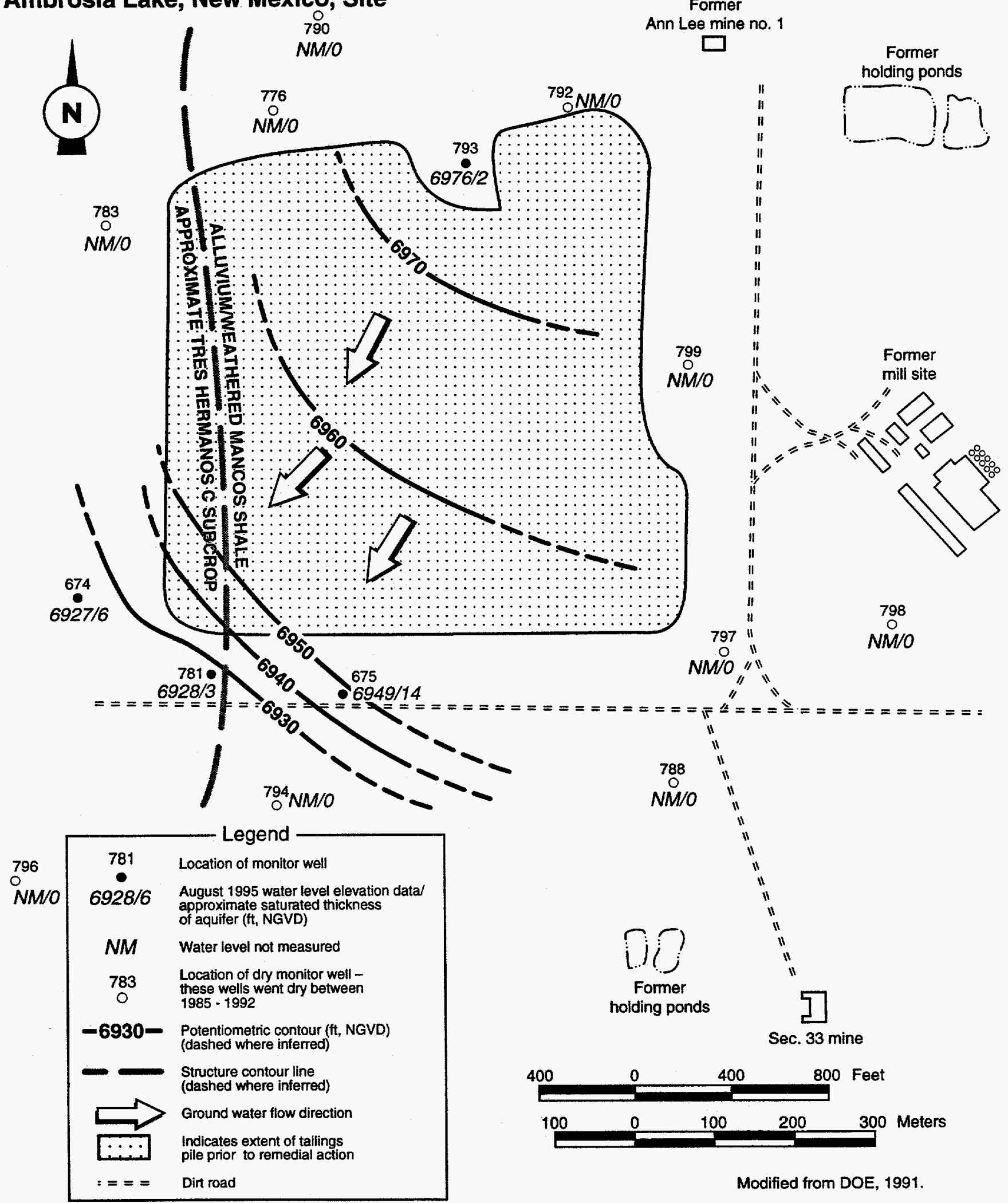

MAC: SITE/AMBRTSP/BASE/POTEN ALUUVIUM 
not hydraulically connected to the alluvium/weathered Mancos Shale unit at the Ambrosia Lake site.

Ground water within both the Tres Hermanos- $C_{1}$ and $-C_{2}$ Sandstone units flows to the northeast in the direction of regional dip under a hydraulic gradient averaging 0.026 from observations made in 1995 (Figures 5.7 and 5.8 ). The average hydraulic conductivity in these units is approximately $3 \times 10^{-4} \mathrm{~cm}$ per second $(0.9 \mathrm{ft}$ per day) and the average linear ground water velocity is approximately $1 \times 10^{-4} \mathrm{~cm}$ per second (0.3 ft per day) (DOE, 1991). The Tres Hermanos-C Sandstone units are unconfined in the vicinity of the Ambrosia Lake site, and ground water elevations from monitor wells completed in both the upper and lower sandstone beds suggest that there is basal saturation in each unit. The Tres Hermanos Sandstone may have been saturated in the premining era, but was dewatered by mine construction activities and seepage down mine shafts and vent holes in the vicinity. The basal saturation evident in recent monitor well ground water level measurements is probably sustained by recharge from the alluvium in the subcrop area.

\section{Tres Hermanos-B and -A Sandstones}

Underlying the Tres Hermanos- $\mathrm{C}_{2}$ Sandstone is an unweathered portion of Mancos Shale that acts as an effective aquitard. The shale is approximately $50 \mathrm{ft}(15 \mathrm{~m})$ thick and is of sufficiently low-hydraulic conductivity to impede the vertical migration of contaminants. A hydraulic conductivity of $4 \times 10^{-8} \mathrm{~cm}$ per second $\left(1.1 \times 10^{-4} \mathrm{ft}\right.$ per day) was estimated in undisturbed Mancos Shale and is probably representative of the vertical hydraulic conductivity of the Mancos Shale aquitard that occurs between the Tres Hermanos- $C$ and the Tres Hermanos-B Sandstones (Thompson and Heggen, 1981). Ground water within the Tres Hermanos-B Sandstone unit flows to the northeast in the direction of regional dip under a hydraulic gradient estimated to be 0.04 (DOE, 1991). Underlying the shale are the Tres Hermanos-B and -A Sandstone units which consist of silty sandstone (Figure 5.3). An aquifer test was performed on the Tres Hermanos-B Sandstone unit yielding an estimated hydraulic conductivity of $5 \times 10^{-4} \mathrm{~cm}$ per second $(1.4 \mathrm{ft}$ per day). The water-bearing capacity of the Tres Hermanos-B and -A Sandstone units is limited and not much greater than the Mancos Shale.

Based on water levels measured from 1985 to 1995, the Tres Hermanos-B Sandstone unit is only partially saturated. Because the unit is relatively thin and only partially saturated, its use as a potential aquifer is limited. Furthermore, the Tres Hermanos-B Sandstone unit subcrops in the alluvium to the west of the site and contamination in the alluvium from the Ambrosia Lake site probably does not recharge this unit. A 75- $\mathrm{ft}(23-\mathrm{m})$-thick shaley siltstone unit underlies the Tres Hermanos-A Sandstone unit and acts as an effective hydraulic barrier to ground water flow. 
Figure 5.7

Potentiometric Surface Map for Tres Hermanos- $C_{1}$ Sandstone Ambrosia Lake, New Mexico, Site

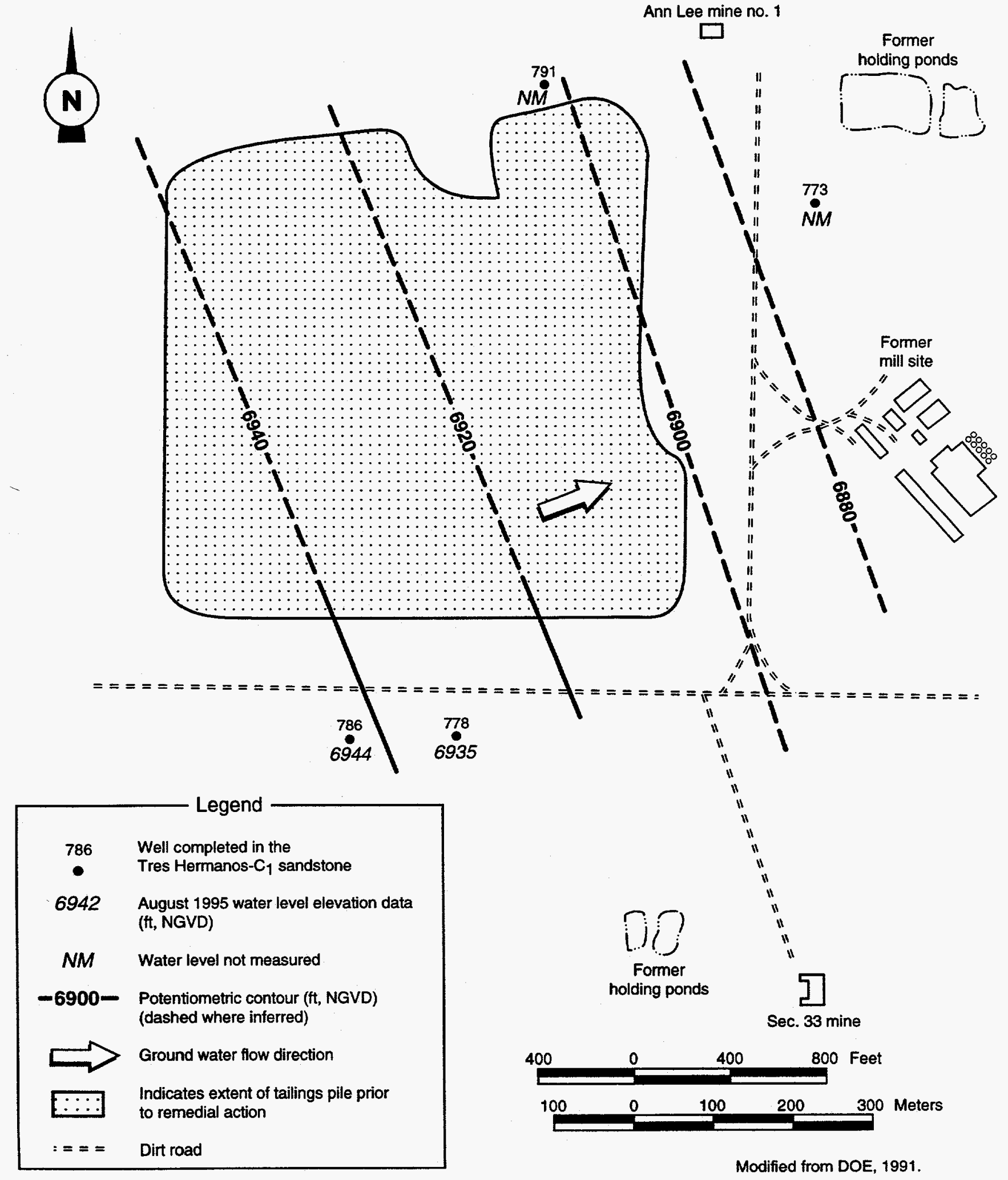

Ann Lee mine no. 1

MAC: SITE/AMB/LTSP/BASE/POTEN HERMANOS-CY 
Figure 5.8

Potentiometric Surface Map for Tres Hermanos- $C_{2}$ Sandstone Ambrosia Lake, New Mexico, Site

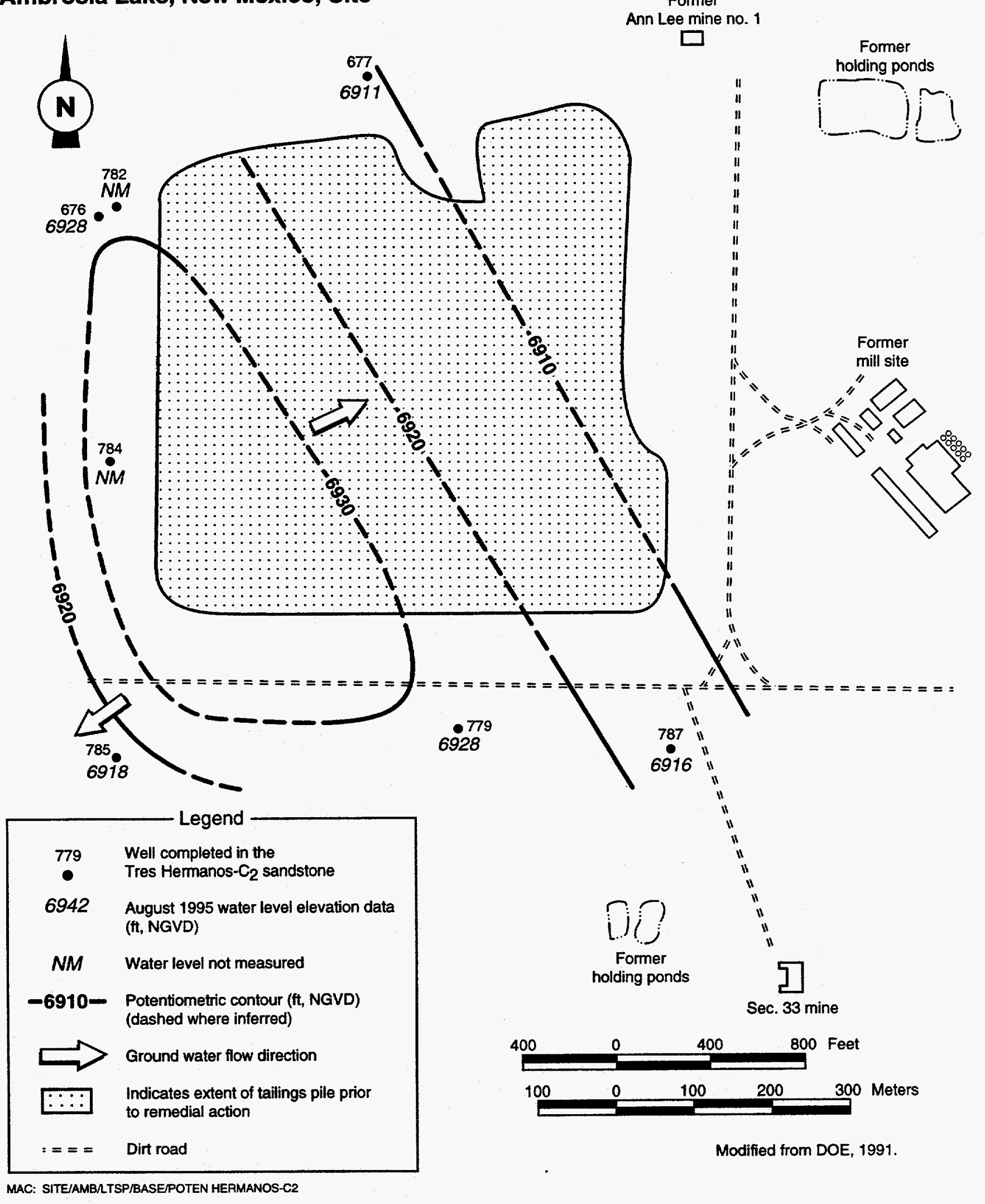




\section{Dakota Sandstone}

The Dakota Sandstone consists of fine to medium grained marine sandstone that is approximately $40 \mathrm{ft}(12 \mathrm{~m})$ thick below the Ambrosia Lake site. The hydraulic conductivity of this unit is estimated to be approximately $6 \times 10^{-4} \mathrm{~cm}$ per second (1.7 ft per day) (Brod and Stone, 1981). The Dakota Sandstone is considered an aquifer although it has a relatively low yield (less than $10 \mathrm{gal}$ [40 L] per minute) and poor water quality, when compared to the underlying Westwater Canyon Member of the Morrison Formation (DOE, 1987). Bostick (1985) reports that the Dakota Sandstone is present at the land surface near the QMC mill approximately $2 \mathrm{mi}(3 \mathrm{~km})$ west of the site and that surface water related to the OMC processing activities was discharged onto the outcrop of the Dakota Sandstone which has caused the contamination of the unit. The discharge of contaminated water at the outcrop area and the discharge of water from mill tailings placed in surrounding mines are the primary sources of contaminants found in the Dakota Sandstone beneath the Ambrosia Lake site.

\section{Morrison Formation}

The stratigraphic units that comprise the Morrison Formation beneath the site include the Brushy Basin Member, Westwater Canyon Member, and the Recapture Member. The Brushy Basin Member acts as an aquitard between the Dakota Sandstone and Westwater Canyon Member.

The Westwater Canyon Member is the principal aquifer in the Ambrosia Lake Mining District and is also the source of uranium ore. Mine pumping began in the mid-1950's to facilitate ore removal from the Westwater Canyon Member. Because of the regional mine pumping, a large ground water depression was created. Ground water flow within the Westwater Canyon Member is probably downdip toward the northeast or toward the potentiometric depression to the southeast under an assumed average hydraulic gradient of 0.026 (DOE, 1991). The average hydraulic conductivity in the Westwater Canyon Member is approximately $4 \times 10^{-4} \mathrm{~cm}$ per second $(1.1 \mathrm{ft}$ per day) and the average linear ground water velocity is approximately $1 \times 10^{-4} \mathrm{~cm}$ per second $(0.3 \mathrm{ft}$ per day) (DOE, 1991). The Recapture Member acts as an aquitard beneath the Westwater Canyon Member because of its thickness $(165 \mathrm{ft}[50 \mathrm{~m}])$ and low permeability.

\subsubsection{Background ground water quality}

Because there was originally no measurable water in the alluvium/weathered Mancos Shale unit and the Tres Hermanos-C Sandstone units, premining ground water quality data are not available. Consequently, the background ground water quality in the uppermost aquifer is considered to be the same as existing water quality because former mining and milling activities created the saturated conditions (Bostick, 1985). Geochemical modeling shows that the ground water within the alluvium/weathered Mancos Shale is derived from tailings seepage and mill makeup water (DOE, 1991). The mill makeup water was generated 
from mine pumping discharge. Modeling results are presented in the remedial action plan (Table D.8.25 of DOE, 1991).

\subsubsection{Ground water quality and extent of contamination}

To define the extent of contaminated ground water at the Ambrosia Lake site, water samples were collected from a DOE monitor well network from 1980 through 1995. Figure 5.2 shows a portion of the DOE monitor well network used to determine current site conditions. Water samples collected from this monitor well network have been analyzed to assess the chemical quality of ground water in the alluvium/weathered Mancos Shale, the Tres Hermanos-C, $-B$, and -A Sandstones, and the Westwater Canyon Member of the Morrison Formation.

The majority of the contaminated ground water contained in the alluvium/ weathered Mancos Shale unit and Tres Hermanos-C Sandstone units in the area of the milling site was derived from water pumped from the Ann Lee Mine, mill process waste water, and some tailings seepage. Because of the large ground water depression created by mine pumping, ground water from all overlying units will tend to migrate downward through mine shafts and vent holes into the Westwater Canyon Member of the Morrison Formation.

\section{Alluvium/weathered Mancos Shale}

Pore water from tailings at the Ambrosia Lake site contained as much as $11,000 \mathrm{mg} / \mathrm{L}$ sulfate (DOE, 19911 . Sulfate is a good indicator of ground water contamination because it is a by-product of milling operations, travels at about the same rate as ground water, and is usually in low concentrations in uncontaminated ground water. A sulfate isopeth map (Figure 5.9) is used to define the extent of tailings-related contamination and, very likely, the extent of ground water in the alluvium/weathered Mancos Shale at the site. Monitor well 620 is located more than $1200 \mathrm{ft}(370 \mathrm{~m})$ southeast of the ground water mound. The contaminated ground water in this well, as indicated by significantly high sulfate concentrations, is assumed to be derived from the former holding ponds located to the east and from transient drainage from the tailings pile that occurred prior to site remedial action. From 1980 through 1994, maximum observed concentrations of arsenic, cadmium, chromium, molybdenum, nitrate, selenium, silver, uranium, and the activities of gross alpha, radium-226, and radium-228 in samples collected from monitor wells completed in the alluvium/weathered Mancos Shale exceeded the maximum concentration limits (MCL) for ground water listed in 40 CFR Part 192, as revised by 60 FR 2854 (Table 5.2) (DOE, 1995).

The Tres Hermanos- $\mathrm{C}_{1}$ Sandstone is separated from the underlying Tres Hermanos $-\mathrm{C}_{2}$ Sandstone by a $10-$ to $15-\mathrm{ft}(3-$ to $5-\mathrm{m})$-thick shale unit. This shale unit retards downward migration of contaminants, resulting in slightly higher levels of contamination in the Tres Hermanos- $C_{1}$ Sandstone (Table 5.3), compared to values in the Tres Hermanos $-C_{2}$ Sandstone (Table 5.4). There are 
Figure 5.9

Sulfate Isopleth Map For Ground Water in the Alluvium/Weathered Mancos Shale Ambrosia Lake, New Mexico, Site

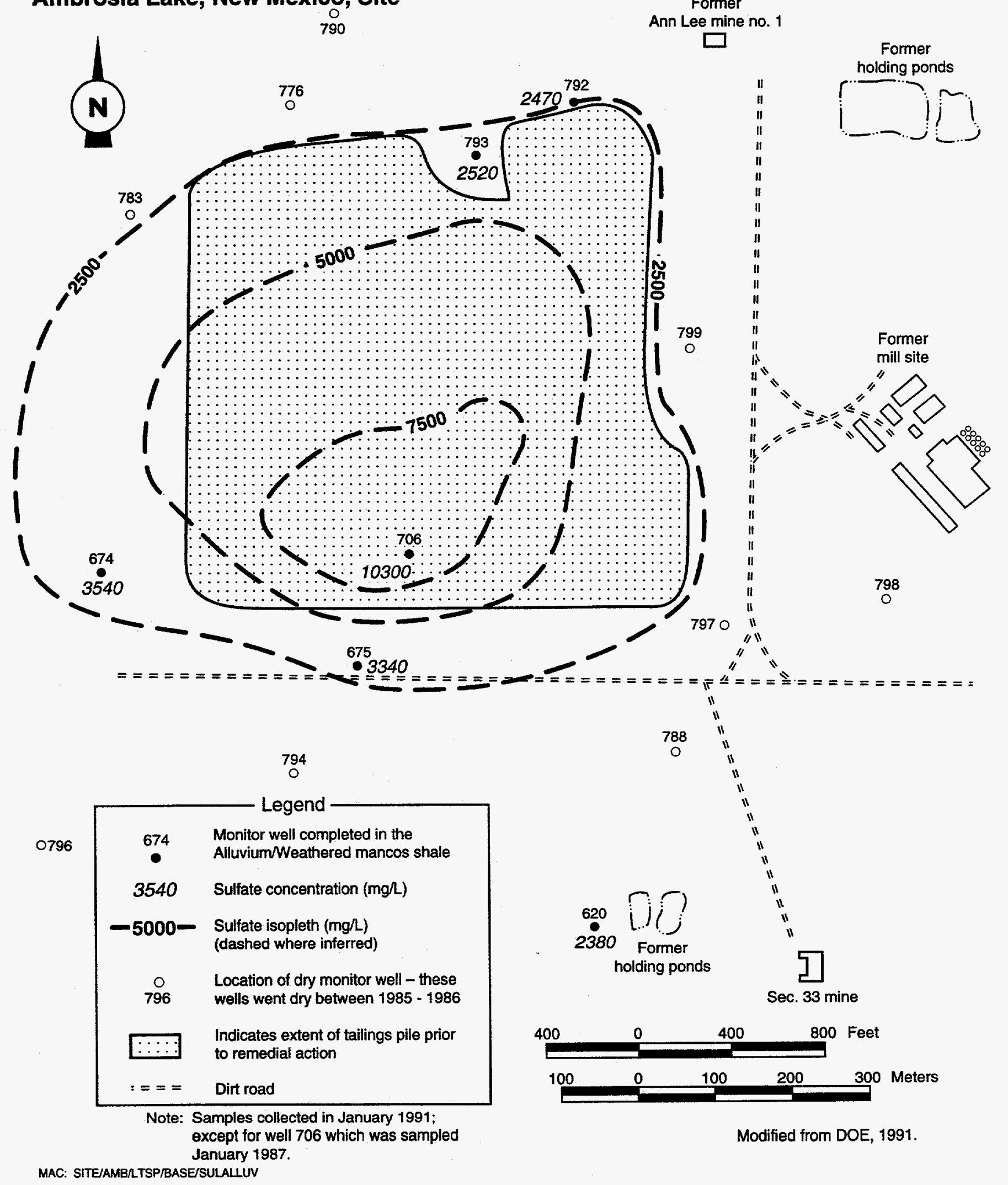


Table 5.2 Maximum observed concentrations of listed constituents in monitor wells located in the alluvium/weathered Mancos Shale at the Ambrosia Lake, New Mexico, site, 1980 to 1994

\begin{tabular}{|c|c|c|c|c|c|c|c|}
\hline \multirow[b]{4}{*}{ Constituent" } & \multirow[b]{3}{*}{$\mathrm{MCL}^{b}$} & \multicolumn{6}{|c|}{ Maximum observed concentration" } \\
\hline & & \multicolumn{6}{|c|}{ Monitor wells } \\
\hline & & 620 & 674 & 675 & 706 & 792 & 793 \\
\hline & & & & $(\mathrm{mg} / \mathrm{L})$ & & & \\
\hline Arsenic & 0.05 & 0.01 & 0.02 & 0.02 & $0.33^{c}$ & 0.016 & 0.016 \\
\hline Barium & 1 & 0.1 & $<0.1$ & 0.01 & $<0.1$ & $<0.1$ & $<0.1$ \\
\hline Cadmium & 0.01 & $<0.001$ & 0.003 & 0.003 & $<0.001$ & 0.01 & $0.013^{c}$ \\
\hline Chromium & 0.05 & $0.16^{c}$ & $<0.01$ & $<0.01$ & $0.06^{c}$ & $0.28^{c}$ & $0.28^{\circ}$ \\
\hline Lead & 0.05 & 0.02 & 0.03 & 0.02 & 0.02 & 0.02 & 0.02 \\
\hline Mercury & 0.002 & $<0.0002$ & $<0.0002$ & $<0.0002$ & $<0.002$ & 0.0007 & 0.0003 \\
\hline Molybdenum & 0.1 & $0.5^{c}$ & $9.81^{c}$ & $2.72^{\circ}$ & $225^{c}$ & $1.87^{c}$ & $2.01^{c}$ \\
\hline Nitrate & $44^{d}$ & 12.1 & $69^{\circ}$ & $252^{c}$ & 25 & 1.8 & $830^{c}$ \\
\hline Selenium & 0.01 & $0.07^{c}$ & $3.1^{c}$ & $0.51^{\circ}$ & $0.088^{c}$ & $2.22^{c}$ & $2.1^{c}$ \\
\hline Silver & 0.05 & 0.04 & 0.01 & 0.02 & $0.15^{c}$ & $0.11^{c}$ & $0.11^{c}$ \\
\hline \multirow{2}{*}{$\begin{array}{l}\text { Combined } \\
\text { Uranium-234 } \\
\text { and }-238\end{array}$} & $0.044^{\circ}$ & $8.22^{c}$ & $10.7^{c}$ & $2.083^{c}$ & $11.1^{c}$ & $3.31^{\circ}$ & $0.393^{c}$ \\
\hline & \multicolumn{7}{|c|}{$\mathrm{pCi} / \mathrm{L}$} \\
\hline $\begin{array}{l}\text { Gross alpha } \\
\text { (excluding } \\
\text { radon and } \\
\text { uranium) }\end{array}$ & 15 & $5300^{c}$ & $2200^{c}$ & $1700^{\circ}$ & $15,000^{\circ}$ & $2400^{\circ}$ & $320^{\circ}$ \\
\hline $\begin{array}{l}\text { Combined } \\
\text { Radium-226 } \\
\text { and }-228\end{array}$ & 5 & $9.13^{c}$ & 0.8 & 4.03 & $131.8^{c}$ & $6.85^{c}$ & 2.3 \\
\hline
\end{tabular}

All concentrations are in $\mathrm{mg} / \mathrm{L}$ unless stated otherwise.

${ }^{b}$ Constituents and maximum concentration limits (MCL) from Table 1 of 40 CFR Part 192, as revised by 60 FR 2854.

'Exceeds MCL.

${ }^{\alpha}$ The $\mathrm{MCL}$ for nitrate as $(\mathrm{N})$ is $10 \mathrm{mg} / \mathrm{L}$.

'The uranium concentration of $0.044 \mathrm{mg} / \mathrm{L}$ is equivalent to $30 \mathrm{pCi} / \mathrm{L}$, which is the MCL. 
Table 5.3 Maximum observed concentrations of listed constituents in monitor wells located in the Tres Hermanos- $\mathrm{C}_{1}$ Sandstone at the Ambrosia Lake, New Mexico, site, 1980 to 1994

\begin{tabular}{|c|c|c|c|}
\hline \multirow[b]{4}{*}{ Constituent $^{b}$} & \multirow[b]{3}{*}{$\mathrm{MCL}^{\mathbf{b}}$} & \multicolumn{2}{|c|}{ Maximum observed concentration } \\
\hline & & \multicolumn{2}{|c|}{ Monitor wells } \\
\hline & & 778 & 786 \\
\hline & \multicolumn{3}{|c|}{ (mg/L) } \\
\hline Arsenic & 0.05 & 0.022 & 0.02 \\
\hline Barium & 1 & $<0.1$ & 0.3 \\
\hline Cadmium & 0.01 & $0.014^{c}$ & $0.013^{c}$ \\
\hline Chromium & 0.05 & $0.22^{c}$ & $0.14^{c}$ \\
\hline Lead & 0.05 & 0.02 & 0.02 \\
\hline Mercury & 0.002 & 0.0005 & 0.0003 \\
\hline Molybdenum & 0.1 & $0.16^{c}$ & $0.34^{c}$ \\
\hline Nitrate & $44^{d}$ & $430^{c}$ & $55^{c}$ \\
\hline Selenium & 0.01 & $0.28^{c}$ & $0.78^{c}$ \\
\hline Silver & 0.05 & $0.06^{c}$ & 0.02 \\
\hline \multirow[t]{2}{*}{ Combined Uranium-234 and -238} & $0.044^{\circ}$ & $11.8^{c}$ & $2.88^{c}$ \\
\hline & \multicolumn{3}{|c|}{$\mathrm{pCi} / \mathrm{L}$} \\
\hline $\begin{array}{l}\text { Gross alpha (excluding radon and } \\
\text { uranium) }\end{array}$ & 15 & $9400^{c}$ & $1300^{\circ}$ \\
\hline Combined Radium-226 and -228 & 5 & $7.93^{c}$ & $9.92^{c}$ \\
\hline
\end{tabular}

${ }^{a}$ All concentrations are in $\mathrm{mg} / \mathrm{L}$ unless stated otherwise.

${ }^{b}$ Constituents and maximum concentration limits (MCL) from Table 1 of 40 CFR Part 192, as revised by 60 FR 2954.

'Exceeds MCL.

${ }^{d}$ The $M C L$ for nitrate as $(\mathrm{N})$ is $10 \mathrm{mg} / \mathrm{L}$.

The uranium concentration of $0.044 \mathrm{mg} / \mathrm{L}$ is equivalent to $30 \mathrm{pCi} / \mathrm{L}$, which is the $\mathrm{MCL}$. 
Table 5.4 Maximum observed concentrations of listed constituents in monitor wells located in the Tres Hermanos-C ${ }_{2}$ Sandstone at the Ambrosia Lake, New Mexico, site, 1980 to 1994

\begin{tabular}{|c|c|c|c|c|c|c|}
\hline \multirow[b]{4}{*}{ Constituent $^{b}$} & \multirow[b]{3}{*}{$\mathbf{M C L}^{\mathbf{b}}$} & \multicolumn{5}{|c|}{ Maximum observed concentration } \\
\hline & & \multicolumn{5}{|c|}{ Monitor wells } \\
\hline & & 779 & 785 & 787 & 677 & 676 \\
\hline & \multicolumn{6}{|c|}{ (mg/L) } \\
\hline Arsenic & 0.05 & 0.025 & 0.012 & 0.019 & $<0.01$ & $<0.01$ \\
\hline Barium & 1 & 0.3 & 0.1 & 0.01 & 0.01 & 0.01 \\
\hline Cadmium & 0.01 & $0.016^{c}$ & $0.024^{c}$ & $0.012^{c}$ & 0.004 & 0.003 \\
\hline Chromium & 0.05 & $0.22^{\mathrm{c}}$ & $0.24^{c}$ & $0.23^{c}$ & $<0.01$ & $<0.01$ \\
\hline Lead & 0.05 & 0.02 & 0.02 & 0.02 & 0.05 & 0.04 \\
\hline Mercury & 0.002 & 0.0006 & 0.0006 & 0.0004 & $<0.0002$ & $<0.0002$ \\
\hline Molybdenum & 0.1 & $0.14^{c}$ & $0.35^{c}$ & $0.25^{c}$ & 0.024 & $0.595^{c}$ \\
\hline Nitrate & $44^{d}$ & 2.29 & 20 & 29 & 6.9 & 25.6 \\
\hline Selenium & 0.01 & $0.092^{c}$ & $0.324^{c}$ & $0.054^{c}$ & $0.037^{c}$ & $0.091^{c}$ \\
\hline Silver & 0.05 & 0.05 & $0.08^{c}$ & $0.09^{c}$ & $<0.01$ & $<0.01$ \\
\hline \multirow{2}{*}{$\begin{array}{l}\text { Combined } \\
\text { Uranium-234 and } \\
-238\end{array}$} & $0.044^{\circ}$ & 0.0238 & $3.30^{\circ}$ & 0.018 & 0.016 & $0.207^{c}$ \\
\hline & \multicolumn{6}{|c|}{ pCi/L } \\
\hline $\begin{array}{l}\text { Gross alpha } \\
\text { (excluding radon and } \\
\text { uranium) }\end{array}$ & 15 & $74^{c}$ & $1900^{c}$ & $57.4^{c}$ & $29^{c}$ & $85.9^{c}$ \\
\hline $\begin{array}{l}\text { Combined } \\
\text { Radium-226 and } \\
-228\end{array}$ & 5 & $5.6^{c}$ & $10.51^{c}$ & 4.2 & $6.45^{c}$ & $24.12^{c}$ \\
\hline $\begin{array}{l}\text { All concentrations a } \\
{ }^{b} \text { Constituents and ma } \\
\text { as revised by } 60 \mathrm{FR} \\
{ }^{c} \text { Exceeds MCL. } \\
\text { dThe MCL for nitrate }\end{array}$ & $\begin{array}{l}\text { in } \mathrm{mg} / \mathrm{L} \\
\text { imum cor } \\
354 .\end{array}$ & $\begin{array}{l}\text { less state } \\
\text { entration }\end{array}$ & $\begin{array}{l}\text { d otherwise. } \\
\text { imits (MCL) f }\end{array}$ & om Table & of $40 \mathrm{CF}$ & Part 192, \\
\hline
\end{tabular}


insufficient data to compile a sulfate isopleth map for the Tres Hermanos- $C_{1}$ Sandstone. A sulfate isopleth map (Figure 5.10) shows the approximate extent of tailings-related contamination in the Tres Hermanos- $C_{2}$ Sandstone. This map indicates that contamination has moved farther downgradient to the northeast as compared to Figure D.8.24 in the remedial action plan (DOE, 1991). From 1980 through 1994, maximum observed concentrations of cadmium, chromium, molybdenum, nitrate, selenium, silver, uranium, and the activities of gross alpha, radium-226, and radium-228 in samples collected from monitor wells completed in the Tres Hermanos- $\mathrm{C}_{2}$ Sandstone exceeded the MCLs for ground water (Table 5.4). Maximum concentrations of several parameters in the Tres Hermanos- $C$ sandstone units have increased over those of previous years indicating that contamination is moving downgradient (DOE, 1995).

\section{Units below the Tres Hermanos-C Sandstone}

Water bearing units below the Tres Hermanos-C Sandstone include, in descending order, the Tres Hermanos-B and -A Sandstones, the Dakota Sandstone, and the Westwater Canyon Member of the Morrison Formation. Ground water from monitor wells completed in these units does not appear to be affected by site-related contamination.

From 1989 to 1994 , nitrate levels increased in monitor well 678 , which is completed in the Tres Hermanos-B Sandstone (DOE, 1995). This increase is probably not related to uranium processing at the Ambrosia Lake site because it is not accompanied by increases in other relatively mobile site-related parameters (e.g. molybdenum, sulfate, or uranium), and nitrate concentrations in monitor well 678 (approximately $3400 \mathrm{mg} / \mathrm{L}$ ) are much higher than average concentrations found in tailings pore fluids (approximately $1400 \mathrm{mg} / \mathrm{L}$ ). Furthermore, the Tres Hermanos-B Sandstone is hydrologically isolated from the alluvium/weathered Mancos Shale unit at the site (see Section 5.1.1). The relatively high nitrate levels are most likely related to releases from the OMC tailings pile (DOE, 1995).

The Westwater Canyon Member is the primary source of uranium ore in the area and was the focus of intense mining-related activity. Thus, mining activities not related to UMTRA Project site tailings seepage introduced many other sources of contamination into the Westwater Canyon Member. The DOE made a comparison of concentrations of contaminants in the Tres Hermanos-C Sandstone with the Westwater Canyon member (Table D.8.26 of DOE, 1991) and concluded that, in general, concentrations of site contaminants in the Tres Hermanos-C Sandstone are lower. This suggests that seepage from the Tres Hermanos- $C$ Sandstone ground water will produce no increases in the concentrations of contaminants in the Westwater Canyon Member.

\subsection{GROUND WATER MONITORING PLAN}

No ground water monitoring is required for the long-term surveillance program at the Ambrosia Lake disposal site for compliance with ground water protection 
Figure 5.10

Sulfate Isopleth Map for Ground Water in the Tres Hermanos- $C_{2}$ Sandstone Ambrosia Lake, New Mexico, Site

Former

Ann Lee mine no. 1

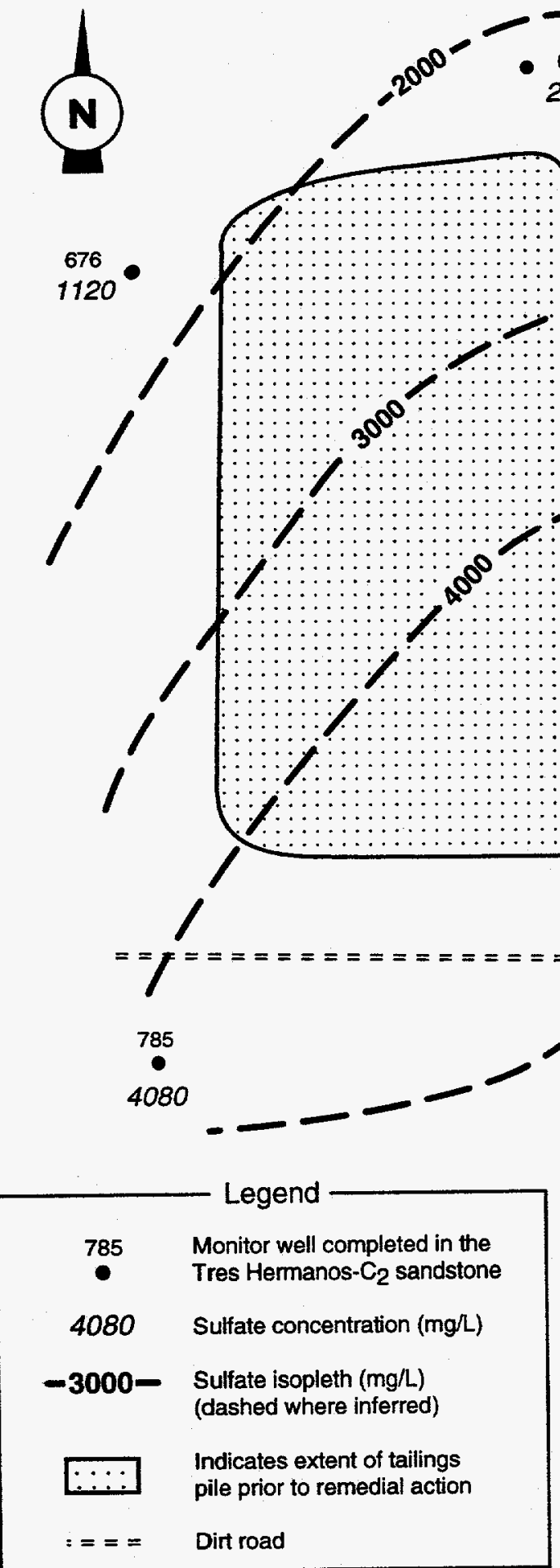

Note: Samples collected in January 1991; except for well 779 which was sampled September 1989.

Former holding ponds

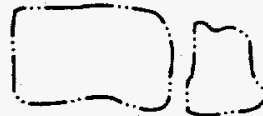


standards at 40 CFR Part 192, Subparts A and C, as revised by 60 FR 2854, or for demonstration of disposal cell performance. The DOE has adequately justified that the proposed supplemental standards are protective of human health and the environment and has demonstrated that the remedial action comes as close to meeting the otherwise applicable standards as is reasonable under the circumstances. Consequently, the NRC has concurred in the application of supplemental standards at the Ambrosia Lake disposal site and the exemption of both the compliance and performance elements of ground water monitoring requirements (NRC, 1990).

The DOE conducted the last scheduled sampling event for the Ambrosia Lake site in August 1995. This event completed the water sampling requirements for the surface remedial action program. The need for additional characterization or ground water sampling is not expected for compliance with 40 CFR Part 192 Subpart $B$, as revised by 60 FR 2854 . The rationale for not monitoring ground water further is discussed in Appendix $E$ of the Ambrosia Lake remedial action plan (DOE, 1991). Attachment 1 contains a copy of the transmittal letter for the NRC's technical evaluation report (NRC, 1990) concurring with the remedial action plan and the ground water protection strategy.

If subsequent evaluations conducted as part of the DOE UMTRA Ground Water Project identify a need to continue ground water monitoring at the Ambrosia Lake disposal site, the scope of the monitoring program will be addressed in a future revision of the LTSP. 


\subsection{SITE INSPECTIONS}

Routine inspections of the Ambrosia Lake disposal site will be conducted to detect progressive change caused by slow-acting natural processes and to identify potential problems before the need for extensive maintenance, repairs, or corrective action. The findings from these inspections will be compared to initial baseline conditions to provide a basis for future inspections.

Each site inspection must be thoroughly documented. An inspection report will be prepared that identifies the findings of the inspection and that records any changes to the disposal cell and site over time. Copies of the report will be submitted to the NRC and will be placed in the Ambrosia Lake DOE permanent site file (Section 10.0).

The three types of site inspections are as follows:

- Routine annual or scheduled site inspections.

- Follow-up inspections.

- Contingency inspections.

The requirements discussed in this section apply to the conduct of routine annual or scheduled site inspections. Additional requirements for follow-up or contingency inspections are discussed in Section 7.0.

\subsection{INSPECTION FREQUENCY}

The Ambrosia Lake disposal site will be inspected annually for the first 5 years after licensing. At the end of the 5-year period, the GJPO will evaluate the need to continue annual inspections, basing its recommendation on an evaluation of the annual reports and any other reports filed for maintenance or unscheduled events. If it is determined that less frequent inspections are required, the GJPO will modify the LTSP and submit it to the NRC for acceptance. Subsequent routine inspections will be considered scheduled site inspections.

\subsection{INSPECTION TEAM}

The inspection team will consist of a chief inspector and one or more assistants. The chief inspector will be a geotechnical engineer, a civil engineer, or an engineering geologist knowledgeable in processes that could adversely affect the site (e.g., geomorphic agents of change). A plant specialist or other qualified person will periodically participate in site inspections. If the annual or scheduled inspection does not coincide with the general growing season, the plant specialist may conduct a separate inspection at a more favorable time.

When they are needed for follow-up or contingency inspections, the team will include additional technical experts to assess the problems under investigation. 
For example, a follow-up inspection by a plant specialist may be required if an inspection team reports significant plant growth on the rock cover.

\subsection{PREPARATION FOR INSPECTION}

Before each inspection, inspectors will complete the following tasks:

- Review the final LTSP, the permanent site file, the previous site inspection report(s) and site inspection map(s), and all maintenance or corrective action reports.

- Prepare the site inspection checklist based on previous inspections or repairs; incorporate any needed modifications.

- Verify and update the names and telephone numbers of all parties with whom access or notification agreements have been executed.

- Verify the DOE 24-hour telephone number and appropriate agency telephone numbers and contacts; arrange to modify the entrance sign, as needed.

- Schedule the site inspection.

- Assemble all equipment needed for the inspection.

- Adjust the magnetic declination of the Brunton compass for that of the Ambrosia Lake area.

- Notify the NRC, OMC, and, if appropriate, the state of New Mexico and adjacent land owners of the schedule for the forthcoming inspection. Names and addresses of adjacent land owners are in the Ambrosia Lake permanent site file.

- Obtain key to gate lock if OMC installs a gate on the access road (see Section 2.3).

\subsection{ROUTINE SITE INSPECTION}

The routine site inspection will cover the disposal cell, the surrounding disposal site area, and the immediate off-site areas. The most significant modifications from natural processes likely will be on the slopes of the disposal cell and in and around the apron. Plant, animal, and human intrusion can also cause modifications to the engineered components of the disposal cell. Site inspections must be able to identify any significant changes or active modifying processes that could potentially adversely impact the disposal cell or the debris pit. Surveillance should be performed to identify unanticipated effects of modifying processes such as severe gully formation, unusually high rate of slope 
erosion, significant changes to vegetation, ephemeral drainage channel changes, and significant modifications by humans or animals.

\subsubsection{On-site areas}

The integrity of the disposal cell will be evaluated from a series of transects walked around the perimeter; along the base, crest, and sideslopes; and in and around the apron. Sufficient transects must be walked so that the disposal cell is thoroughly covered and inspected. Diagonal transects of the crest will be made, and the edge of the crest will be walked. Additional transects, at approximately 50 -yard $(50-\mathrm{m})$ intervals, will be walked along the sideslopes and rock apron. Transects along the entire length of the drainage swales will be made to determine whether they have been functioning as designed and can be expected to continue to function properly.

The complete length of transects along the engineered disposal cell and its immediate perimeter will be examined for evidence of the following:

- Structural instability resulting from differential settlement, subsidence, cracking, sliding, or creep.

- Erosion as evidenced by developing rills or gullies.

- Sedimentation or debris buildup.

- Rapid rock cover deterioration caused by weathering or erosion.

- Seepage from disposal cell.

- Intrusive activity (inadvertent or deliberate) by humans such as removal of rock or other disposal cell material or vandalism.

- Burrowing or other significant disturbance by animals.

- Volunteer plant growth on the rock-covered slopes of the disposal cell.

At minimum, the surrounding disposal site area will be monitored for evidence of erosion caused by wind, sheet wash, or changes in drainage patterns. Site inspections also will monitor damage to or disturbance of the following features:

- Permanent site-surveillance features.

- Ground water monitor wells.

- Drainage swales.

- Planned site area vegetation (see below).

- Vent shafts.

- Demolition debris pit. 
The disposal cell has a rock cover and there is no planned vegetation on the disposal cell. However, remedial action of the areas surrounding the disposal cell included revegetation with grasses and forbs (Table 6.1). The area surrounding the disposal cell will be monitored during site inspections to determine the success of the revegetation efforts.

\subsubsection{Off-site areas}

The area within a maximum of $0.25 \mathrm{mi}(0.40 \mathrm{~km})$ from the center of the disposal site will be visually surveyed from the disposal site for evidence of landuse changes that indicate increased human activity such as renewed grazing or mining. New roads or paths, changes in vegetation, and relevant geomorphic features like gullies or ephemeral drainage channels will also be observed and potential impact noted. Inspectors should avoid trespassing on private property surrounding the site. If there is a need for closer inspection of off-site features, inspectors shall obtain permission in advance from the property owner.

A restrictive easement on QMC property west of the disposal site (Tract 2B-E) allows the DOE access to carry out the requirements of this LTSP (see Figure 1.1 and Attachment 2). Conventional mining is restricted within $400 \mathrm{ft}$ $(120 \mathrm{~m})$ of the westerly edge of the disposal cell; however, OMC retains mineral rights in this area and any resumption of solution mining should be noted. OMC is required to maintain the woven wire and barbed wire fencing to the south and west of the disposal site and the cattle guard across the access road at the site entrance for 5 years (Charlton, 1995). The fencing and cattle guard will be inspected to determine if this maintenance requirement is being met. The vent shaft outside the west side of the site will be monitored during site inspections to determine if the property owner permanently closes it. If the shaft is closed, information on the closure method should be obtained for the site file.

Off-site DOE monitor wells shall be inspected until they are properly abandoned.

\subsection{SITE INSPECTION DOCUMENTATION}

All site inspection activities and observations should be recorded and described using the as-builts, site inspection checklist, site inspection map, a field notebook, and photographs. Documentary evidence of anomalous, new, or unexpected conditions or situations must be sufficient to record developing trends and to enable the responsible agency to make reasonable decisions concerning follow-up inspections, custodial maintenance, and corrective action. A site inspection report will be prepared documenting the findings and recommendations from each field inspection.

\subsubsection{Site inspection checklist}

The initial site inspection checklist (Attachment 4 ) is a guideline for the inspectors to prepare for and conduct site inspections. All checklist items should be completed. Annotations should be made on the checklist to add more 
Table 6.1 Revegetation seeding mixes, Ambrosia Lake, New Mexico, site

\begin{tabular}{|c|c|}
\hline & Seeding rate \\
\hline Location and seed species & $\begin{array}{l}\text { Live seed pounds per acre } \\
\text { (kg/ha) }\end{array}$ \\
\hline \multicolumn{2}{|l|}{ Drainage swales and ditches } \\
\hline slender wheatgrass (San Luis) & $6(1)$ \\
\hline western wheatgrass (Arriba) & $6(1)$ \\
\hline \multicolumn{2}{|c|}{ Final grade, except drainage swales and ditches } \\
\hline western wheatgrass (Arriba) & $6(1)$ \\
\hline Indian ricegrass (Paloma) & $6(1)$ \\
\hline alkali sacaton (native) & $2(0.4)$ \\
\hline sand dropseed & $2(0.4)$ \\
\hline four-wing saltbush (native) & $2(0.4)$ \\
\hline Rocky Mountain penstemon (Bandera) & $1(0.2)$ \\
\hline
\end{tabular}

$\mathrm{kg} / \mathrm{ha}$ - kilograms per hectare.

detailed information and all entries must be clearly stated and legible because the completed checklist becomes part of the permanent field record of the inspection. Upon completion of the field inspection, Section D of the site inspection checklist (Attachment 4) must be completed and the certification statement must be signed.

After each inspection is complete, the checklist may be revised, if necessary, to include new information or to delete items that are no longer pertinent.

Revisions to the checklist will be documented in the inspection report.

\subsubsection{Site inspection maps}

The disposal site baseline map (Plate 1) will serve as the base for preparing the site inspection map. The inspection team will use copies of the site inspection map during site inspections and annotate these field maps as necessary to record pertinent information.

A new site inspection map will be prepared after each scheduled inspection for inclusion in the inspection report. The site inspection map must include the following information:

- Inspection traverses.

- Photographic locations.

- Locations and descriptions of any new, anomalous, or unexpected features. 
- Features identified during previous inspections for observation or monitoring.

- Inspection date and type of inspection.

Upon completion of the field inspection, the annotated inspection map may be used to prepare overlays for the as-built drawings or revise the drawings to note any potential problems or other site conditions requiring attention.

\subsubsection{Site inspection photographs}

A photographic record of the site inspection must be maintained. Site conditions should be documented by ground photographs to record developing trends and to enable the DOE to evaluate the need for and extent of future activities. If possible, any site feature or condition requiring inspectors to make a written comment, explanation, or description will be photographed. A site inspection photo log will be used to record the photographs (Attachment 3). A separate photo log should be completed for each roll of exposed film, with an entry for each photograph. All features will be photographed and recorded as specified below. The inspectors may determine the number of photographs, the view angles, and the lenses used to ensure that sufficient photographs are taken for agency review.

If possible, a photograph will include a reference point such as a survey monument, boundary monument, site marker, or monitor well. For large-scale features such as drainage swales or disposal cell slopes, a north arrow and a scale will be included for reference. For specific areas where a photograph is used to monitor change over time, the distance from the feature and the azimuth should be recorded, and all subsequent photographs should be taken from the same orientation to provide an accurate picture of changing conditions. The magnetic declination of the compass should be corrected for true north. This information will also be provided on the inspection checklist and photo log.

\section{Features to be photographed}

The following site features should be documented with photographs during scheduled inspections at the Ambrosia Lake disposal site:

- Permanent site-surveillance features (Section 4.0) and survey control point for site grid coordinate system.

- Access road.

- Drainage swales and debris pit area.

- The disposal cell (top, sides, apron, and surrounding area). Panoramic sequences of photographs from selected vantage points may be used for this purpose. 
- Vent shafts.

- Any evidence of erosion (e.g., gullies, rivulets, and rills) that the inspector considers significant and includes in the text of the inspection report.

- Any off-site features that may affect the site in the future and that the inspector considers significant and includes in the inspection report.

- Vegetation (site area and disposal cell slopes).

- Monitor wells (until abandoned).

Any new or potential problem areas identified during a site inspection must be well documented with photographs. Photographs should also be taken to record developing trends and to allow inspectors to make reasonable decisions concerning additional inspections, custodial maintenance or repairs, or corrective action. All site inspection photographs, as well as all corresponding photo log forms, will be maintained in the permanent site file.

\subsubsection{Site inspection report}

The GJPO will prepare a site inspection report after every routine site inspection that discusses scope of the inspection, observations made, and conclusions drawn from the inspection. At a minimum the inspection report will include:

- Narrative of site inspection including a description of the site conditions.

- Site inspection checklists, including the signed inspection certification, and any relevant supporting documentation.

- Site inspection map and other drawings, maps, or figures, as required.

- Inspection photographs and photo log sheets.

- Recommendations for additional follow-up inspections, custodial maintenance, or repairs, if required.

- Custodial maintenance or repair report and certification, if any was performed.

If new conditions requiring monitoring or immediate action are discovered during the inspection, the inspection report will detail any observed modifying features, and will include a description of the problem, relevant measurements and photographs, and an assessment of possible impacts. The description of the modifying process will include information such as the following:

- Extent of area affected. 
- Number, spacing, length, depth, and width of features (e.g., gullies).

- Locations and patterns of occurrence.

- Species, location and density of volunteer plant growth.

Evidence of deliberate and repeated human intrusion such as cover removal, extensive vandalism to signs and monuments, or the presence of wellestablished trails will be described in detail. While inadvertent or casual intrusion by humans is not of great concern, all signs of vandalism will be noted since evidence of continued vandalism may indicated the need to implement more active measures to control site access.

All site inspection reports, as well as all supporting documentation, will be maintained in the permanent site file. 


\subsection{UNSCHEDULED INSPECTIONS}

An unscheduled inspection may be triggered by reports or information that site integrity has been or may be compromised. Such inspections are classified as either follow-up inspections or contingency inspections depending on the nature of the triggering event. The scope of these unscheduled inspections may be broad and similar in nature to routine site inspections (Section 6.0) or focused on specific areas of concern. When unusual damage or disruption is discovered, an inspection report must be submitted to the NRC within 60 days.

\subsection{FOLLOW-UP INSPECTIONS}

Follow-up inspections investigate and quantify specific problems found during a routine annual or scheduled inspection, other DOE-initiated activity, or other confirmed report of damage or other significant threat to the disposal site. Follow-up inspections determine whether processes currently active at or near the site threaten site security or stability, and evaluate the need for custodial maintenance, repair, or other corrective action.

Because triggering events usually involve first-hand knowledge of a problem, planning of follow-up inspections often can be focused on investigating a specific concern. Depending on the nature of the problem, specialized equipment may be required. Follow-up inspections should be made by technical specialists in an appropriate discipline (e.g., a soils scientist or geomorphologist to evaluate erosion processes).

The follow-up inspection begins with an on-site visit to determine the need for definitive tests or studies. Additional visits may be scheduled if more data are needed to draw conclusions and to recommend corrective action.

\subsection{CONTINGENCY INSPECTIONS}

Contingency inspections are unscheduled inspections ordered by the DOE when it receives information indicating that site integrity may be threatened. Events that could trigger contingency inspections include reports of vandalism or intrusion by humans or animals. Notifications of severe rainstorms, flash floods, or unusual events such as tornadoes or earthquakes in the vicinity of the Ambrosia lake site also can trigger contingency inspections.

Contingency inspections should be made by technical specialists in an appropriate discipline if a specifically required skill is identified in advance.

\subsection{DOCUMENTATION REQUIREMENTS}

The results of all unscheduled inspections shall be documented in written reports. Other appropriate documentation such as photographs, measurements, 
and drawings also shall be included. At a minimum, an unscheduled inspection report must include the following:

- A description of the problem.

- A preliminary assessment of the custodial maintenance or repair or corrective action required.

- Conclusions and recommendations.

- Assessment data, including field and inspection data, and photographs.

- Names and qualifications of the field inspectors.

A copy of all unscheduled inspection reports and all other data and documentation will be maintained in the permanent site file. 


\subsection{CUSTODIAL MAINTENANCE OR REPAIR}

Routine maintenance is not planned for the Ambrosia Lake disposal site. However, custodial maintenance or repair will be performed as needed. Discoveries from routine site inspections, follow-up inspections, and contingency inspections will determine the need for maintenance or repairs.

\subsection{UNSCHEDULED MAINTENANCE OR REPAIR}

Unscheduled custodial maintenance or repair required at the Ambrosia Lake disposal site may include the following:

- Replacing the warning signs. Deterioration from weathering or damage from vandalism may necessitate installation of new warning signs.

- Removing deep-rooted plants that invade the topsiope of the disposal cell. Volunteer plant growth on the disposal cell cover may need to be eradicated using methods such as selective spraying or physical removal.

- Reseeding areas surrounding the disposal cell. Conditions such as drought may cause the vegetation to die. This may require reseeding, which should be coordinated with the local U.S. Soil Conservation Service agent.

The DOE will prepare a statement of work along with a purchase order to authorize these kinds of repair. The statement of work will include contractor qualifications.

If repairs are needed to address problems that may affect the integrity of the disposal cell or compliance with 40 CFR Part 192, the NRC must approve the recommended action in advance. Such action will be treated as a corrective action (Section 9.0).

\subsection{DOCUMENTATION REQUIREMENTS}

After the work is completed, the contractor must submit verification of the completed work and/or a written report if the action is considered significant. The DOE will inspect the site, as necessary, and review the report before certifying that all work is completed in accordance with all required specifications.

The site inspection report and the annual report to the NRC must include the following information on unscheduled maintenance or repair:

- Summary of work required.

- Work order, purchase order, or statement of work.

- Contractor qualifications, if applicable. 
LONG-TERM SURVEILLANCE PLAN FOR THE

- Contractor documentation of work completion.

- DOE certification of work completion.

Copies of all records, documentation, and certifications will be included in the permanent site file. 


\subsection{CORRECTIVE ACTION}

Natural or unforeseen events could threaten the stability of the disposal cell and require corrective action. Examples of conditions could require corrective action are:

- Surface rupture or subsidence of the disposal cell.

- Development of rills or gullies or slope instability on the disposal cell.

- Deterioration of the erosion protection rock on the disposal cell.

- Seepage originating from the disposal cell.

- Gully development on or immediately adjacent to disposal site property that could affect the integrity of the disposal cell.

- Damage to the cell cover or disposal site property from extreme seismic events, other catastrophic events, or vandalism.

\subsection{PROBLEM IDENTIFICATION AND EVALUATION}

Site inspections by qualified inspectors are designed to identify problems at the developmental stage. In some cases, the required corrective action may be readily determined. However, extreme natural events or unanticipated events may require additional data or evaluative monitoring to assess whether uncorrected problems would threaten site integrity. In any event, the DOE will evaluate the factors that caused the problem and identify actions to mitigate the impact and prevent recurrence. An on-site inspection or preliminary assessment would include, but is not limited to, the following:

- Identifying the nature and extent of the problem.

- Reevaluating germane engineering design parameters.

- Establishing a data collection and/or evaluative monitoring program to quantify the magnitude of the problem.

\subsection{CORRECTIVE ACTION IMPLEMENTATION}

When a potential problem is identified, the GJPO will submit a preliminary assessment report to the NRC for review no more than 60 days after the problem is identified. The preliminary assessment report will evaluate the problem and recommend the next step (e.g., immediate action or continued evaluation). After the NRC reviews the report and recommendations, the DOE will develop a corrective action plan for NRC approval. Once the NRC approves the corrective action, the DOE will implement the plan. In some cases, 
corrective action could include temporary emergency measures taken prior to the completion of the normal approval process. The UMTRA Project long-term surveillance program guidance (DOE, 1992a) contains additional details on the corrective action process.

NRC regulations do not stipulate a time frame for implementing corrective action. However, 40 CFR Part 192, as revised by 60 FR 2854, requires that a corrective action program begin within 18 months after a finding of an exceedance in established ground water concentration limits. This time frame also will be followed for any corrective actions implemented at the Ambrosia Lake disposal site. Assessing the extent of a problem and developing a corrective action plan will not be considered initiation of the corrective action program.

\subsection{DOCUMENTATION REQUIREMENTS}

In addition to the preliminary assessment report, the DOE will prepare progress reports on each corrective action while it is under way or under evaluation. The NRC will be informed of all potential problems and solutions.

After corrective action is complete, DOE will certify all work and submit a certification statement and supporting documentation to the NRC for review and concurrence. A copy of the certification statement will become part of the permanent site file, as will all reports, data, and documentation generated during the corrective action. 


\subsection{RECORD KEEPING AND REPORTING}

The DOE will maintain a permanent site file containing all information needed to prepare for and conduct site surveillance. The GJPO will prepare reports documenting the activities conducted under the long-term surveillance program. The inspection reports and supporting documentation placed in the permanent site file will accomplish the following:

- Document the history of disposal site performance.

- Demonstrate to the NRC that licensing provisions were met.

- Provide the DOE and the NRC with information needed to forecast future sitesurveillance and monitoring needs.

- Inform the public that site integrity has been maintained.

\subsection{RECORD KEEPING REQUIREMENTS}

After the site is brought under the general license, the DOE will compile copies of site documentation required by the long-term surveillance program guidance (DOE, 1992a) for the Ambrosia Lake disposal site permanent site file. The permanent site file will be maintained at the GJPO in Grand Junction, Colorado. All original deeds, custody agreements, and other property documents will be kept at the DOE Facilities and Property Management Division, Albuquerque Operations Office, Albuquerque, New Mexico. Other original UMTRA Project records will be archived by the UPDCC.

The surveillance and maintenance documentation identified in other sections of this LTSP will be maintained at the GJPO and become part of the permanent site file. The GJPO will update the site file as necessary after disposal site inspections, maintenance activities, or corrective actions are complete. These records will be handled in accordance with DOE Order 1324.2A, Records Disposition, to ensure their proper handling, maintenance, and disposition. The archival procedures set forth in 41 CFR Part 101 and 36 CFR Parts 1220-1238 (Subchapter B - Records Management) will be followed. All information will be available at the GJPO for NRC and public review.

\subsection{REPORTING REQUIREMENTS}

The GJPO will prepare an annual report documenting the results site inspections and any other activities conducted in conjunction with the long-term surveillance program. In accordance with 10 CFR Part 40 requirements, the annual report will be submitted to the NRC no more than 90 days after the date of the last UMTRA Project site inspection for that calendar year. This submittal will also include reports on any follow-up or contingency inspections and custodial 
maintenance or repairs performed during the year. A copy of this annual report will be sent to the state of New Mexico as well.

Following any inspection where unusual damage or disruption is discovered at the Ambrosia Lake disposal site, a preliminary report assessing the impact must be submitted to the NRC within 60 days of the initial discovery of the problem. If maintenance or repair or corrective action is warranted, the DOE will notify the NRC and, if appropriate, the state of New Mexico and the owners of adjacent property. The NRC will receive a copy of corrective action plans and each corrective action progress report, or the reports will be attached to the annual report. The NRC will be informed of all potential problems and solutions.

While no ground water monitoring will be required at the Ambrosia Lake disposal site under the long-term surveillance program, the results of any ground water monitoring conducted by the DOE will be submitted to the NRC along with the annual report. 


\subsection{EMERGENCY NOTIFICATION AND RESPONSE}

The Ambrosia Lake disposal cell was designed to comply with 40 CFR Part 192, Subpart A, with minimum maintenance and oversight for up to 1000 years, or at least 200 years. However, unforeseen events could create problems affecting the disposal cell's ability to remain in compliance with these standards. Therefore, the DOE has requested notification from state, federal, and local agencies of discoveries or reports of any purposeful intrusion or damage at the disposal site as well as the occurrence of earthquakes, tornadoes, or floods in the disposal site area.

\subsection{AGENCY AGREEMENTS}

The DOE is negotiating notification agreements with the McKinley County Sheriff's Office, the U.S. Geological Survey's National Earthquake Information Center, and the New Mexico area office of the National Weather Service. Copies of the agreements are presented in Attachment 5. The designated point of contact for emergency notification is the GJPO 24-hour phone line (970-248-6070). In addition, the DOE Albuquerque Operations Office 24-hour phone number (505-845-4667) is posted on the Ambrosia Lake disposal site entrance sign so the public can notify the DOE if problems are discovered.

In accordance with the agreements, the DOE UMTRA Project will be the designated facility contact until the disposal site is brought under general license. After that, the designated facility contact will be the GJPO.

Response letters from all of the agencies will be kept in the permanent site file.

Contact lists and telephone numbers for all agencies with whom the DOE has entered into agreements will be updated annually, in conjunction with the site inspection, for inclusion in the disposal site inspection report. To further solidify written agreements with these agencies, the GJPO will contact these agencies periodically to update them about the concerns for the Ambrosia Lake disposal site.

\subsection{NOTIFICATION TRIGGERS}

A variety of natural and human-induced events have the potential to adversely impact the disposal site. While all potential events cannot be foreseen, DOE's agency agreements mentioned above will trigger notification of the more probable occurrences that could cause an emergency response.

\section{County Sheriff}

The DOE has requested that the McKinley County Sheriff's Office notify the GJPO of any unusual occurrences in the disposal site area that may affect the site. Such occurrences might include reports of vandalism, severe overgrazing, range fires, damage to access roads, and localized flash floods. 


\section{National Earthquake Information Center}

The DOE subscribes to the U.S. Geological Survey's Early Warning Service for notification when an earthquake is of sufficient magnitude to threaten a disposal site. This service provides data on the magnitude of the event and the location of the epicenter.

The National Earthquake Information Center in Denver, Colorado, has agreed to notify the DOE if a seismic event occurs that fits any of the following descriptions:

- Any earthquake of magnitude 3.0 or greater, within 0.3 degree (about $20 \mathrm{mi}$ [30 km] at N35.41 latitude and W107.80 longitude) of the site.

- Any earthquake of magnitude $\mathbf{5 . 0}$ or greater, within 1.0 degree (about $70 \mathrm{mi}$ [110 km] at N35.41 latitude and W107.80 longitude) of the site.

\section{National Weather Service}

The DOE has requested the New Mexico area office of the National Weather Service in Albuquerque, New Mexico, to notify the GJPO of any flash flood or tornado warnings in southeastern McKinley County, New Mexico.

\subsection{EMERGENCY RESPONSE}

Responses to notifications of potential emergency situations will follow a graded approach. The nature of the occurrence and the amount of first-hand knowledge available will determine the DOE's response. For example, if DOE receives a report that the disposal cell has ruptured and tailings are exposed, an unscheduled inspection (Section 7.0) would be conducted as soon as possible. However, a report that a flash flood warning was issued for the area might trigger a request that the county sheriff drive by the site to see if there are signs that a flash flood actually occurred in the immediate vicinity of the site.

In all cases, the notification, response, and any followup activities shall be documented. This documentation will become part of the permanent site file. Emergency notifications and responses also will be included in the annual site report to the NRC. 


\subsection{QUALITY ASSURANCE}

The GJPO is responsible for developing quality assurance procedures specific to the UMTRA Project long-term surveillance program. The GJPO has implemented a quality assurance plan (DOE, 1992b) that specifies the following requirements:

- Program planning.

- Program activities, including inspections, site maintenance, corrective action, and emergency responses.

- Monitoring, if required.

- Personnel qualifications and training.

- Program surveillance and audits.

- Analytical quality assurance.

- Analytical data validation.

All site inspections, monitoring data, records, photographs, maps, and other information related to the LTSP for the Ambrosia Lake disposal site are subject to formal and unannounced audits by the DOE or the NRC. 



\subsection{PERSONNEL HEALTH AND SAFETY}

After a disposal site is licensed and transferred to the GJPO, the GJPO is responsible for assuring health and safety during long-term surveillance program activities. The GJPO will determine health and safety requirements for its personnel and GJPO contractors in accordance with applicable DOE Orders and federal regulations.

\subsection{HEALTH AND SAFETY DURING INSPECTIONS}

Specific safety concerns at the Ambrosia Lake disposal site include slip, trip, and fall hazards; animal bites (primarily poisonous snakes); animal and bird hunting seasons; heat and cold stress; punctures and cuts; and road hazards. A number of abandoned mines exist near the site, presenting potential falling and cave-in hazards to intruders. Also, mine spoils stored nearby contain materials with elevated levels of radioactivity and may contain undetonated explosives.

Safety equipment should be taken to the site to reduce exposures to identified hazards and to provide first aid, if the need arises. The disposal cell controls radiological releases from the buried residual radioactive material; therefore, radiation exposure tracking and dosimetry badges are not needed.

Inspectors should verify the locations and telephone numbers for emergency medical and law enforcement facilities prior to visiting the site.

\section{Emergency response}

Law enforcement in McKinley County, New Mexico, is provided by the county sheriff based in Gallup with a substation in Thoreau. In eastern McKinley County, the sheriff is assisted by the state police who maintain an office in Grants, New Mexico, which is in Cibola County. In McKinley County, an emergency services dispatcher can be contacted by dialing 911 or 505-722-7205. In addition, the following 24-hour emergency phone numbers for the Grants-Milan, New Mexico, area are pertinent:

- Ambulance: 505-287-7446 (Grants)

- Cibola General Hospital: 505-287-4446 (Grants)

- McKinley County Sheriff: 505-862-7155 (Thoreau substation)

- Cibola County Sheriff: 505-287-9479 (Grants)

- New Mexico State Police: 505-287-4141 (Grants)

- Fire: 505-287-3776 (Milan) or 505-287-4401 (Grants)

Community medical services are not available in the immediate vicinity of the Ambrosia Lake disposal site. The nearest emergency room is located at the Cibola General Hospital in Grants, about a 30-minute drive from the site. Emergency medical care is also available in Albuquerque, $80 \mathrm{mi}(130 \mathrm{~km})$ east of Grants on Interstate 40, and Gallup, $60 \mathrm{mi}(100 \mathrm{~km})$ west of Grants on 
Interstate 40. Personnel traveling to the site should ensure that at least one member of the inspection team has taken first aid and cardiopulmonary resuscitation training.

\section{Directions to Cibola General Hospital}

Cibola General Hospital, which has 24-hour emergency room services, is approximately $25 \mathrm{mi}(40 \mathrm{~km})$ from the Ambrosia Lake site (Figure 13.1). Directions to Cibola General Hospital from the site are as follows:

- From the Ambrosia Lake disposal site proceed west on the east-west section line road to NM 509.

- Turn left onto NM 509 and follow it southeast to NM 605.

- Turn right onto NM 605 and proceed southwest to NM 122 (historic U.S. Highway 66).

- Turn left onto NM 122 and follow it east about $3.9 \mathrm{mi}(6.2 \mathrm{~km})$ through Milan and into Grants to First Street (NM 547).

- Turn left onto First Street and follow it $0.9 \mathrm{mi}(1.4 \mathrm{~km})$ to Roosevelt Avenue.

- Turn right onto Roosevelt (still NM 547) and follow it $0.7 \mathrm{mi}(1.1 \mathrm{~km}$ ) east to Bonita Avenue.

- Turn left onto Bonita Avenue. The hospital is $0.1 \mathrm{mi}(0.2 \mathrm{~km})$ north on the right at 1212 Bonita.

\section{Location of nearest telephone}

There is no telephone available at the Ambrosia Lake disposal site. The nearest public telephone is located at the Love's truck stop at Interstate 40 Exit 79 about $20 \mathrm{mi}(30 \mathrm{~km})$ from the site. In an emergency, a private telephone is available at the QMC Company site less than $3 \mathrm{mi}(5 \mathrm{~km})$ from the Ambrosia Lake site (Figure 2.2). Directions to the OMC offices are as follows:

- From the Ambrosia Lake disposal site proceed west on the east-west gravel road to NM 509.

- Turn right onto NM 509 and follow it northwest about $0.5 \mathrm{mi}(0.8 \mathrm{~km})$.

- Turn left onto a paved road (marked with a QMC sign) and proceed west about $0.5 \mathrm{mi}(0.8 \mathrm{~km})$ to a fork in the road. 


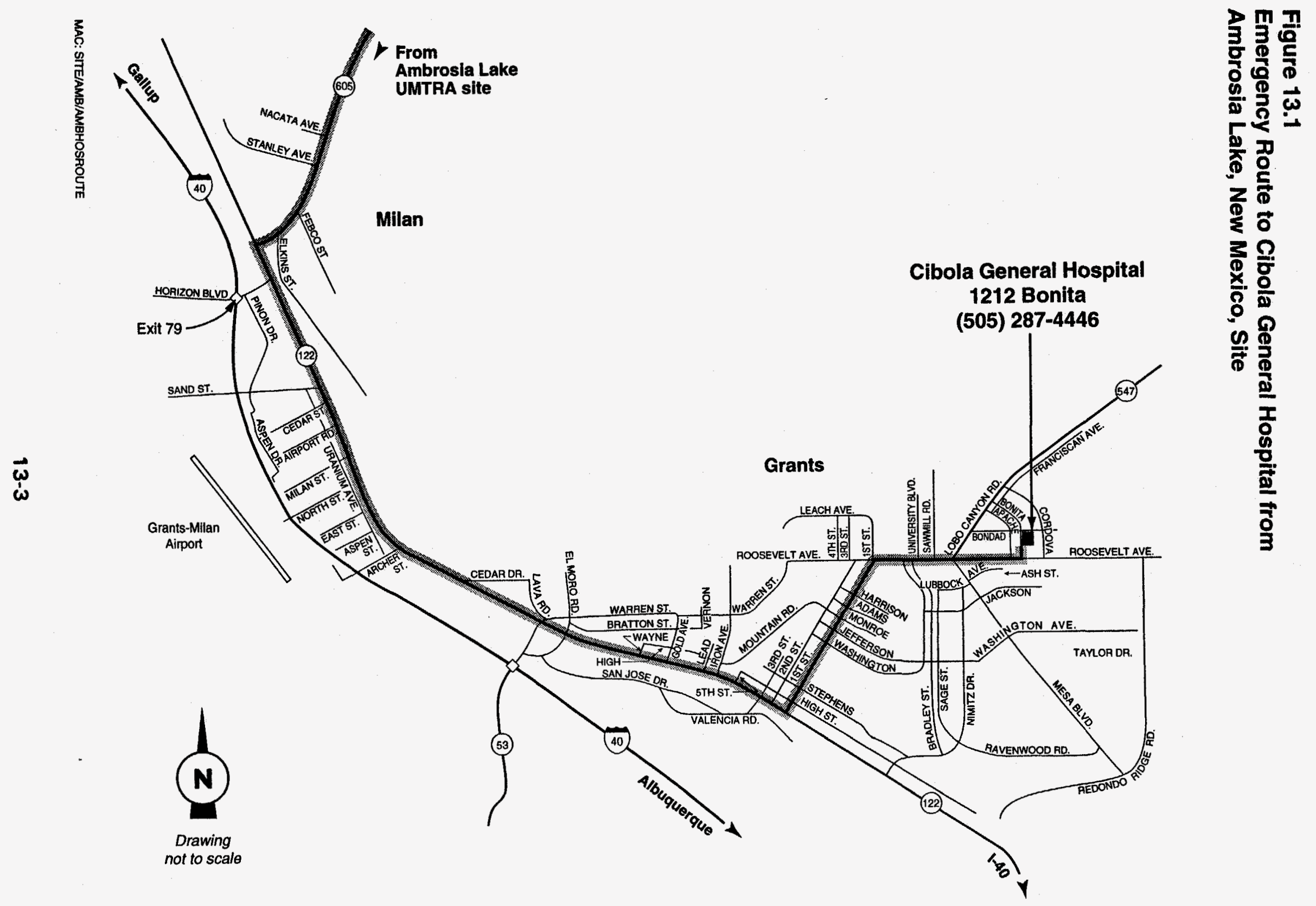


- Take the left fork (marked with a QMC sign) and travel south about $0.9 \mathrm{mi}$ $(1.4 \mathrm{~km})$ to the QMC site entrance.

- Follow posted signs to the QMC offices. A phone is available at the General Office during normal working hours. A phone also is available at the Guard Office, which is manned 24 hours a day.

While the QMC telephone is available for emergency use, a mobile phone should be taken on site inspections.

\subsection{REPORTABLE INCIDENTS}

Accidents or injuries occurring during site inspections may be reportable incidents under DOE Order 232.1, Occurrence Reporting and Processing of Operations Information. The condition or event must be reported to the GJPO facility manager or designated contact within 8 hours of the occurrence. The GJPO facility manager's 24-hour telephone number for reporting an incident is 970-248-6070. In addition, some accidents or injuries may be reportable under 29 CFR Part 1904. 


\subsection{LIST OF CONTRIBUTORS}

The following individuals contributed to the preparation of this LTSP.

\begin{tabular}{|c|c|}
\hline Name & Contribution \\
\hline M. B. Leaf & $\begin{array}{l}\text { Site manager, document sponsor, } \\
\text { document review }\end{array}$ \\
\hline A. Vollmer & Document coordination, primary author \\
\hline E. Larsen & Hydrogeology \\
\hline P. Martinez & Real estate \\
\hline $\begin{array}{l}\text { M. Abrams, D. Erskine, A. Holm, O. } \\
\text { Holmquist, J. Lommler, R. Neri Zagal, } \\
\text { J. Ritchey, C. Saumur }\end{array}$ & Document review \\
\hline D. Kahl & Technical editing \\
\hline L. Sanchez & Word processing \\
\hline B. Harvey & Graphic design \\
\hline
\end{tabular}




\subsection{REFERENCES}

Bostick, K., 1985. Ground-Water Discharge Plan Analysis for Kerr-McGee Nuclear Corporation, Ambrosia Lake Uranium Mill, Quivira Mining Company, Ground Water Section, Ground Water Quality and Hazardous Waste Bureau, New Mexico Environmental Improvement Division, Santa Fe, New Mexico.

Brod, R. C. 1979, Hydrogeology and Water Resources of the Ambrosia Lake-San Mateo Area, McKinley and Valencia Counties, New Mexico, M.S. Thesis, New Mexico Institute of Mining and Technology, Socorro, New Mexico.

Brod, R C., and W. J. Stone, 1981. Hydrogeology of Ambrosia Lake-San Mateo Area, McKinley and Cibola Counties, New Mexico, Hydrologic Sheet 2, New Mexico Bureau of Mines and Mineral Resources, Santa Fe, New Mexico.

Charlton, D. A., 1995. Letter from MK-Ferguson to C. Duran, Jacobs Engineering, Subject: Remedial Action Agreements Amendments - DE-R004-93AL74843, AM-002; DE-R004-91AL74825, AM-004, UPDCC File Loc. No. 16.35.0, Albuquerque, New Mexico, 25 April 1995.

Charlton, D. A., 1993. Letter from MK-Ferguson to M.D. Freeman, Quivira Mining Company, Subject: Remedial Action Agreement - DE-R004-93AL74843, AM002, UPDCC File Loc. No. 16.35.0, Albuquerque, New Mexico, 1 September 1993.

DOE (U.S. Department of Energy), 1995. Site Observational Work Plan for the UMTRA Project Site at Ambrosia Lake, New Mexico, DOE/AL/62350-159, Rev. O, prepared by Jacobs Engineering Group, Inc., for DOE UMTRA Project Office, Albuquerque Operations Office, Albuquerque, New Mexico.

DOE (U.S. Department of Energy), 1992a. Guidance for Implementing the UMTRA Project Long-Term Surveillance Program, final, UMTRA-DOE/AL-350125.0000, Rev. 1, DOE UMTRA Project Office, Albuquerque Operations Office, Albuquerque, New Mexico.

DOE (U.S. Department of Energy), 1992b. Long-Term Surveillance and Maintenance Program Quality Assurance Program Plan, P-GJPO-152, prepared for the U.S. Department of Energy by Chem Nuclear Geotech, Inc., DOE Grand Junction Projects Office, Grand Junction, Colorado.

DOE (U.S. Department of Energy), 1991. Remedial Action Plan and Site Conceptual Design for Stabilization of the Inactive Uranium Mill Tailings Site at Ambrosia Lake, New Mexico, final, UMTRA-DOE/AL-050516.0000, DOE UMTRA Project Office, Albuquerque Operations Office, Albuquerque, New Mexico. 
DOE (U.S. Department of Energy), 1987. Environmental Assessment of Remedial Action at the Ambrosia Lake Uranium Mill Tailings Site, Ambrosia Lake, New Mexico, DOE/EA-0322, DOE UMTRA Project Office, Albuquerque Operations Office, Albuquerque, New Mexico.

DOE (U.S. Department of Energy), 1985. Cooperative Agreement Between the United States Department of Energy and State of New Mexico, DOE Cooperative Agreement No. DE-FC04-85AL20533, DOE UMTRA Project Office, Albuquerque Operations Office, Albuquerque, New Mexico.

Kelly, T. E., R. L. Link, and M. R. Schipper, 1980. "Effects of Uranium Mining on Ground Water in Ambrosia Lake Area, New Mexico," in Geology and Technology of the Grants Uranium Region 1979, New Mexico Bureau of Mines and Mineral Resources, Mem. 38, pp. 313-319.

Merritt, R. C., 1971. The Extractive Metallurgy of Uranium, prepared for the U.S. Atomic Energy Commission by Colorado School of Mines Research Institute, Golden, Colorado.

MK-ES (Morrison Knudsen - Environmental Services), 1992. UMTRA Project, Ambrosia Lake, New Mexico, Surveillance and Maintenance Subcontract Documents Final Design for Review, prepared by MK-ES for the DOE UMTRA Project Office, Albuquerque Operations Office, Albuquerque, New Mexico.

MK-F (MK-Ferguson), 1995. Ambrosia Lake, New Mexico, Draft Completion Report, prepared by MK-F for the DOE UMTRA Project, DOE Environmental Restoration Division, Albuquerque Operations Office, Albuquerque, New Mexico.

NRC (U.S. Nuclear Regulatory Commission), 1990. Final Technical Evaluation Report for DOE's Proposed Remedial Action, Ambrosia Lake UMTRA Project Site, New Mexico, Uranium Recovery Field Office, NRC Region IV, Denver, Colorado.

Pommerening, R. A., 1992. Letter from MK-Ferguson to M.D. Freeman, Quivira Mining Company, Subject: Remedial Action Agreement - DE-R004-91 AL74825, AM004, UPDCC File Loc. No. 16.35.0, Albuquerque, New Mexico, 20 February 1992.

Purtymun, W. D., C. L Weinke, and D. R. Dreesen, 1977. Geology and Hydrology in the Vicinity of the Inactive Uranium Mill Tailings Pile, Ambrosia Lake, New Mexico, LA-6839-MS, Los Alamos Scientific Laboratory, Los Alamos, New Mexico.

Thompson, B. M., and R. J. Heggen, 1981. "Contaminant Transport from Uranium Mill Tailings in Ambrosia Lake, New Mexico," in Proceedings of the Third Annual Symposium on Uranium Mill Tailings Management, 26-27 October 1981, Civil Engineering Department, Colorado State University, Fort Collins, Colorado. 


\section{CODE OF FEDERAL REGULATIONS}

10 CFR Part 40, Domestic Licensing of Source Material, U.S. Nuclear Regulatory Commission.

29 CFR Part 1904, Recording and Reporting Occupational Injuries and IIInessess, Occupational Safety and Health Administration.

36 CFR Parts 1220-1238, National Archives and Records, Subchapter B - Records Management, National Archives and Records Administration.

40 CFR Part 192, Health and Environmental Protection Standards for Uranium and Thorium Mill Tailings, U.S. Environmental Protection Agency.

41 CFR Part 101, Federal Property Management Regulations, General Services Administration.

\section{DOE ORDERS}

Order 1324.2A, Records Disposition, 13 September 1988, U.S. Department of Energy, Washington, D.C.

Order 232.1, Occurrence Reporting and Processing of Operations Information, 25 September 1995, U.S. Department of Energy, Washington, D.C.

\section{FEDERAL REGISTER}

48 FR 602, Health and Environmental Protection Standards for Uranium and Thorium Mill

Tailings, 5 January 1983, U.S. Environmental Protection Agency.

60 FR 2854, Groundwater Standards for Remedial Actions at Inactive Uranium Processing Sites, 11 January 1995, U.S. Environmental Protection Agency.

\section{UNITED STATES CODE}

42 USC $\$ 2011$ et seq.. Atomic Energy Act of 1954, 30 August 1954, as amended.

42 USC $\$ 4321$ et seq., National Environmental Policy Act, 1 January 1970.

42 USC $\$ 7901$ et seq., Uranium Mill Tailings Radiation Control Act of 1978, 8 November 1978, as amended. 
ATTACHMENT 1

NRC CONCURRENCE DOCUMENTATION

(To be provided when received) 


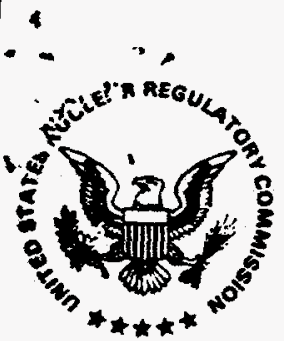

URFO:DLJ
NRC/UMT/UM. ニーー

UNITED STATES

\section{NUCLEAR REGULATORY COMMISSION}

RECION IN

URANIUM RECOVERY FELL OFFICE

$80 \times 20205$

DENVER, COLORADO

Docket No. WH-67

DEC 311990

Mark L. Matthews, Project Manager

Uranium Mill Tailings Project Office

U.S. Department of Energy

P.0. Box 5400

Albuquerque, New Mexico 87115

Dear Mr. Matthews:

The U.S. Nuclear Regulatory Commission (NRC) staff has completed its review of the Remedial Action Plan and Site Conceptual Design (RAP) and all associated documentation pertinent to the proposed remedial action for the uranium mill tailings site at Ambrosia Lake, New Mexico. Our review is documented in the enclosed Technical Evaluation Report (TER), which discusses the NRC staff's evaluation of the proposed remedial action for compliance with the EPA standards.

Based on our review, we are prepared to conditionally concur in DOE's proposed remedial action, with one open issue identified. This issue is related to DOE's deferral of ground-water cleanup until after promulgation of EPA's final ground-water protection standards. While the NRC staff considers DOE's deferral to be acceptable, it precludes us from being able to fully concur in the proposed remedial action. Therefore, our. concurrence will be conditional until we determine that DOE has adequately addressed this issue. You will note that the enclosed signature pages have been annotated to indicate that the concurrence is conditional.

If you have any questions regarding information in the enclosed TER, please contact me at FTS 776-2805.

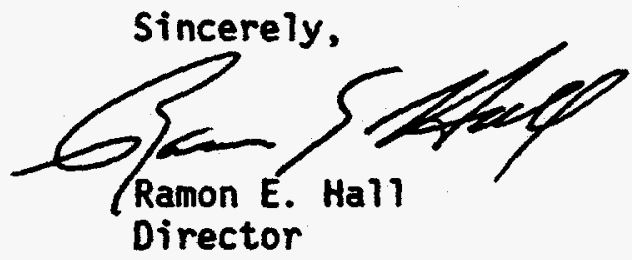

Enclosures:

Technical Evaluation Report and Signature Pages

cc:

C. Cormier, DOE

M. Abrams, DOE

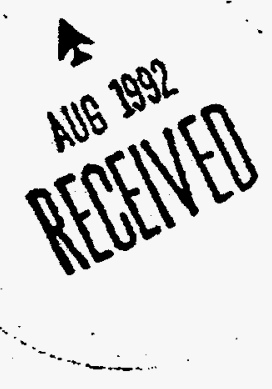




\section{ATTACHMENT 2}

SITE REAL ESTATE INFORMATION 



\section{SITE REAL ESTATE INFORMATION}

\section{GENERAL}

Under the requirements of the Uranium Mill Tailings Radiation Control Act of 1978, as amended, the state of New Mexico acquired the former processing site at Ambrosia Lake, New Mexico, to allow the U.S. Department of Energy (DOE) to perform remedial action consisting of consolidation and stabilization of residual radioactive materials on-site.

The state acquired the site property in two portions, Tracts $A$ and $B$. The state acquired the surface estate for Tract A from United Nuclear Corporation. The Tract A surface estate consists of 282.4 acres (ac) (114.3 hectares [ha]). The subsurface estate beneath Tract $A$ was divided into patented and unpatented mining claims. The unpatented claims, which corresponded to 234.7 ac $(95.0 \mathrm{ha})$, were acquired from the Bureau of Land Management via a jurisdictional transfer. The transfer was published in the Federal Register on 12 March 1991. The three patented claims corresponding to 47.7 ac (19.3 ha) were purchased and conveyed from HELCA Mining Company via a warranty deed. The total subsurface acreage equals that of the Tract $A$ surface estate.

Tract $B$ is comprised of two parcels: Tracts $B-1$ and B-2E. The state acquired Tract B-1, which consists of 5.3 ac (2.1 ha), from Quivira Mining Company in fee simple to accommodate construction of a portion of the disposal cell. The state also acquired a permanent restrictive easement interest in Tract B2-E, which consists of 68.3 ac (27.6 ha). The restrictive easement allows the DOE to carry out the requirements of the longterm surveillance plan. Specifically, the easement allows permanent access to the tract for maintenance of the permanent features constructed in accordance with the DOE Ambrosia Lake site remedial action plan. A copy of the restrictive easement and agreement is included at the end of this Attachment.

\section{TRANSFER OF TITLE TO THE DISPOSAL SITE}

The state of New Mexico and the U.S. Army Corps of Engineers' (USACE) Albuquerque District are working on a draft deed to convey title to the site from the state of New Mexico to the United States of America under the jurisdiction of the DOE. In accordance with a memorandum of understanding between the DOE and the USACE, the USACE will conduct an examination of the title documentation provided by the state to identify any possible exception(s). Any exceptions identified will be cured through a joint effort between the state and the USACE. Once the curative actions, if any, are complete, the USACE will execute the title transfer on behalf of the DOE and record the deed at the local County Recorder's Office. At that time, the title recordation information will be incorporated into this Attachment.

\section{LEGAL DESCRIPTIONS}

The legal descriptions for Tract $A$ and Tract $B$ follow. The description for Tract $B$ includes both Tract B-1 and B-2E. The restrictive easement and agreement that follows this section 
contains the legal description of Tract B-2E. Complete copies of the final real estate documentation will be placed in the permanent site file.

\section{Tract A}

A certain tract or parcel of land lying and being situate in Section 28, T. 14 N., R. 9 W., N.M.P.M., being more particularly described as follows to wit:

Beginning at a point for the southwest corner of said tract or parcel of land, said same point being the Section Corner common to Section 28, 29, 32, and 33, T. 14 N., R. 9 W., N.M.P.M., set by Albuquerque Engineering and marked by a brass cap monument; thence N. $00^{\circ} 19^{\prime} 29^{\prime \prime}$ E. along the westerly line of said tract or parcel of land and the Section lines common to Sections 28 and 29, T. 14 N., R. 9 W., N.M.P.M., a distance of 2,955.39 feet $(\mathrm{ft})$ to a point for the northwest corner; thence S. $90^{\circ} 00^{\prime} 00^{\prime \prime} \mathrm{E}$. along the northerly line of said tract or parcel of land, a distance of $4,183.37 \mathrm{ft}$ to a point for the northeast corner of said tract; thence S. $00^{\circ} 46^{\prime} 00^{\prime \prime} \mathrm{W}$. along the easterly line of said tract or parcel, a distance of $2,940.86 \mathrm{ft}$ to a point for the southeast corner of said tract; thence $S$. $89^{\circ} 47^{\prime} 49^{\prime \prime} W$. along the southerly line of said tract or parcel of land and the section line common to Sections 28 and 33, T. 14 N., R. 9 W., N.M.P.M., a distance of 4,160.80 ft to a brass cap for the section corner, said same point being the true point and place of beginning, containing 282.345 ac, more or less.

\section{Tract $B$ (fee and restrictive easement parcels)}

A certain tract or parcel of land lying and being situate in Section 29, T. 14 N., R. 9 W., N.M.P.M., being more particularly described as follows to wit:

Beginning at a point for the southeast corner of said tract or parcel of land, said same point being the section corner common to Sections 28, 29, 32, and 33, T. 14 N., R. 9 W., N.M.P.M., set by Albuquerque Engineering and marked by a brass cap monument; thence S. $89^{\circ} 47^{\prime} 49^{\prime \prime} \mathrm{W}$. along the southerly line (section line common to Sections 29 and 32, T. 14 N., R. 9 W., N.M.P.M.) of said tract or parcel of land a distance of $1,076.47 \mathrm{ft}$ to a point for the southwest corner; thence N. $00^{\circ} 00^{\prime} 00^{\prime \prime} \mathrm{E}$. along the westerly line of said tract or parcel of land a distance of $2,959.16 \mathrm{ft}$ to a point for the northwest corner; thence S. $90^{\circ} 00^{\prime} 00^{\prime \prime}$ E. along the northerly line of said tract or parcel of land, a distance of $1,093.21 \mathrm{ft}$ to a point for the northeast corner; thence S. $00^{\circ} 19^{\prime} 29^{\prime \prime} \mathrm{W}$. along the easterly line of said tract or parcel of land and the section line common to Sections 28 and 29, T. 14 N., R. 9 W., N.M.P.M., a distance of $2,955.39 \mathrm{ft}$ to a brass cap for the section corner, said point being the true point and place of beginning, containing 73.648 ac, more or less. 


\section{Restrictive Easement and Agreement}

THIS Restrictive Easement is granted by QUIVIRA MINING COMPANY, a Delaware corporation, 6305 Waterford Blvd., Suite 325 , Oklahoma City, oK 73118, (hereinafter called Quivira) to the Property Control Division of the General Services Department of the state of New Mexico (hereinafter called state).

MHEREAS, the Uranium Mill Tailings Radiation Control Act of 1978, Public Law 95-604 (hereinafter called the Act), approved November 8, 1978, authorizes the Secretary of the United states Department of Energy (hereinafter called the secretary and DOE, respectively) to enter into agreements with affected states to cooperatively perform and share the costs of remedial action at designated inactive uranium mill tailings sites and associated vicinity properties, including the inactive uranium mill tailings site located in Ambrosia Iake, New Mexico (hereinafter called the Ambrosia Site), and

WHEREAs, pursuant to Title I of the Act, the United states of America, represented by DOE, and the state have entered into a cooperative agreement (hereinafter called the cooperative Agreement) in order to implement a jointly-conducted program of assessment and remedial action at the Ambrosia site, together with certain real property contiguous to the Ambrosia site which has been designated by DOEias a vicinity Property, and

WHEREAS, Quivira owns certain real property adjacent to the Ambrosia site, and

WHEREAS, DOE and the state have determined that it is appropriate to atquire a permanent restrictive easement on that real property held by Quivira adjacent to the Ambrosia site in order to carry out the purposes of the Act and the cooperative Agreement,

NOW, THEREFORE:

QUIVIRA, for itself, its successors and assigns, for consideration paid, grants to the Property Control Division of the General Services Department of the state of New Mexico, and the state hereby accepts, an easement and right in perpetuity to and over any and all portions of the following described land in Mckinley County, New Mexico for the purposes described herein:

A certain tract or parcel of land lying and being situate in Section 29, T.14N., R.9W., N.M.P.M., being more particularly described as follows, to wit:

Beginning at a point for the southeast corner of said tract or parcel of land, and from whence the section corner common to 
Sections $28,29,32$ \& 33, T.14N., R.9W., N.M.P.M. set by Albuquerque Engineering and marked with a brass cap bears $N$. $89^{\circ} 47^{\prime} 49^{\prime \prime} \mathrm{E}$. a distance of 120.00 feet; thence N. $00^{\circ} 19 \cdot 29^{\prime} \mathrm{E}$. along the easterly line of said tract or parcel of land a distance of $1,955.37$ feet to an angle; thence $\mathrm{N}$. $8^{\circ} 47^{\prime} 49^{\prime \prime} \mathrm{E}$. along said easterly line a distance of 120.00 feet to an angle point, said point lying on the section line common to sections 28 29. T.14N., R.9W. N M.P.M.; thence N.00'19'29" E. along said easterly and sectior line a distance of $1,000.02$ feet to a point for the northee $5=$ corner of said tract or parcel of land; thence N. $90^{\circ} 00^{\prime} 00^{\prime \prime} w$. along the northerly Iine of said tract or parcel of land a distance of 1,093.21 feet to a point for the northwest corner of said tract or parcel of land; thence S. $00^{\circ} 00^{\prime} 0^{\prime \prime} w$. along the westerly line of said tract or parcel of land a distance of $2,959.16$ feet to a point for the southwest corner of said tract or parcel of land, said same point lying on the section line common to sections 29 32, T.14N., R.9W., N.M.P.M.; thence N. $89^{\circ} 47^{\prime} 49^{N}$ E. along said southerly and section line a distance of 956.47 feet to the point for the southeast corner of said tract or parcel of land, said same point being the true point and place of beginning.

Said land being a portion of the $E 1 / 2$ SE $1 / 4$ section $29, T .14 N .$, R.9W., containing 68.261 acres more or less and shown as Tract B-2E in the survey of J. Robert Martinez, N.M.P.L.S. No. 4076, dated October 11, 1991 attached hereto as Exhibit $A$ and incorporated herein by reference.

\section{RIGHTS OF USE AND CONDITIONS:}

The State, DOE, the U.S. Nuclear Regulatory Commission (hereinafter called the NRC), and their authorized representatives, contractors and subcontractors are granted the right to go on the land described above and hereinafter called Tract B-2E solely for the following purposes:

a. For long-term surveillance and maintenance of the Ambrosia site. Access will be coordinated as closely as possible with Quivira to minimize interference with Quivira's activities and to cooperate with Quivira's scheduling.

b. For maintenance of surface contours and other permanent features constructed in accordance with the DOE Ambrosia Site Remedial Action plan and/or as documented in the DOE Ambrosia site Completion Report.

The state or DOF: will restore the property to its previous 
condition after use of the land as granted herein.

This right of use is granted upon the condition that the state, DOE, NRC and their authorized representatives, contractors, and subcontractors shall comply fully with all applicable federal. state and local laws and regulations (including without limitations those relating to environmental and reclamation obligations), shall allow no wastes of any kind to be placed or stored on the property, and will keep the premises free of all liens and encumbrances, whether for taxes, materials, labor or otherwise, relating to the ownership, occupancy, use or operations conducted on or with respect to Tract $\mathrm{B}-2 \mathrm{E}$.

\section{SPECIAI RESTRICTIONS ON IAND USE BY OUIVTRA:}

For purposes of this easement and as indicated on Exhibit A, Tract B-2E is comprised of 68.261 acres in its entirety. within this acreage are two smaller portions of land referred to on Exhibit $A$ as the Upper Restricted Area, and the Lower Restricted Area, which encompass 16.202 acres, and 11.028 acres, respectively. The following special land use restrictions placed upon Tract B-2E apply to the tract in its entirety or to one or both of the restricted areas:

a. Feeder pipe lines in the Upper Restricted Area over 2 " in diameter shall be buried. Feeder pipe lines in the Lower Restricted Area greater than $4^{\prime \prime}$ in diameter shall be perpendicular: $( \pm 20$ degrees) to the contours, or buried. Quivira shali use only a buried header line, which may remain buried at the end of its life. Quivira shall recontour any completed features.

b. Drilling fluid pits may be placed anywhere on Tract B-2E, so long as they are filled and recontoured after use. Quivira shall fill and recontour arilling fluid pits in the Upper Restricted Area within four weeks after use, or as field conditions permit.

c. Chemical mixing pits may be placed anywhere outside of the Upper Restricted Area. Those in the Lower Restricted Area shall be no larger than $30^{\prime} \times 30^{\prime}$. Quivira shall backfill and recontour after the chemical mixing pits are no longer needed.

d. Temporary housing may be placed anywhere outside of the Upper Restricted Area. Temporary housing in the Lower Restricted Area shall be no larger than $20^{\circ}$ by $20^{\prime}$, and any above-surface grade foundation must be removed at the time of removal of the temporary housing. Quivira shall recontour within four weeks of removal of the temporary housing, or as field conditions permit. 
e. Old stope leach wells where installed shall be sealed in an appropriate manner and the sealing documented to the DOE, with a copy to the New Hexico Environment Department, Hazardous and Radioactive Materials Bureau. Sealing shall be by means of a $7^{\prime}$ concrete plug beginning $3^{\prime}$ below the surface, with soil fill in the remaining 3 ', compacted or sealed in accordance with applicable federal, state and local 1aw. Quivira shall seal the wells within three months after a well becomes unserviceable or Quivira has no future plans to use the we11. In any event, Quivira shall not allow conditions to deteriorate to erosional conditions.

f. Quivira shall provide the DOE and the New Mexico Environment Department, Hazardous and Radioactive Materials Bureau, the iocations of all present wells installed and any wells installed or sealed in the future.

g. There shall be no conventional mining methods used within $400^{\prime}$ of the vertical plane extending downward from the most westerly edge of the pile embankment to be constructed and as documented in the DOE Ambrosia site Completion Report. This prohibition does not apply to in-situ leaching.

h. There shall be a maximum of 300 p.s.i. at the top of the casing if in-situ leaching is used.

i. Except as specifically provided hérein, Quivira reserves the right to use Tract $B-2 E$ for all other purposes so long as such use will in no way hinder, interfere with or prevent the proper and reasonable use for which this easement has been granted.

\section{SPECIAI PROVISIONS:}

a. The state or federal government, whichever holds title to the Ambrosia site at the time, shall have a one-time option to purchase in fee simple at fair market value the surface and subsurface of Tract B-2E after Quivira has exhausted the minerals if Quivira offers such land for sale. The option must be exercised within 120 days from receipt of written notice by the New Mexico Environment Department, Office of General Counsel, and the DOE's Albuquerque Field office, that Quivira desires to sell Tract B-2E. The title will be conveyed by warranty deed, contingent on a title insurance policy insuring Quivira and the state in a form acceptable to each, except for any encumbrances placed on the land as a result of DOE's or the state's use of the land. In addition to the recording of this document, Quivira shall give notice of 
this agreement to any successor in interest prior to transfer of any rights held by Quivira, and shall simultaneously verify to the state, c/o New Hexico Environment Department, office of General Counsel, and the DOE Albuquerque Field office, that such notice has been given.

b. Compliance with the terms of this agreement shall not excuse Quivira from compliance with the requirements of all applicable federal, state, and local laws and regulations respecting any past or future use of or operations conducted on Tract B-2E by Quivira.

c. If any of the conditions or provisions of this Easement should be deemed by a court of competent jurisdiction to be invalid or unenforceable in any respect, the remainder of said conditions or provistons and the remaining provisions of this easement shall all continue to be fully effective and enforceable.

d. This easement and all conditions and provisions herein shall be binding on and inure to the benefit of the parties hereto and their respective successors or assigns.

e. This easement and all provisions and conditions herein shall be construed in accordance with the laws of the state of New Nexico.

f. This agreement in no way waives rights or claims, if any, any parties may have or hereafter acquire under the New Mexico Tort Claims Act, SS 41-4-1 through 41-4-27 NMSA 1978, or under the Federal Tort claims Act, 28 U.S.C. SS 2671 et seg.. and any rights or claims they may now or hereafter have against the United States, the state of New Mexico, their agencies, contractors, sub-contractors, agents or employees on account of any matters whatsoever whether similar or dissimilar to the foregoing.

g. The state shall provide and cause its contractors, and seek to cause DOE and its contractors, to provide to Quivira copies of all baseline environmental data collected on Tract $B-2 E$ and copies of all groundwater analyses and fluid level data collected from monitor wells completed on Sections 29 and 33, T14N, R9W.

h. The state, it's successors and assigns, shall require its Contractors that are to perform maintenance on Tract B-2E for the state, it's successors and assigns, to provide Quivira, prior to contractor entering upon Tract B-2E, Certificates of Insurance evidencing comprehensive general liability insurance of not less than $\$ 1$ million 
and providing for 30 days prior notice by. the insurance company to Quivira of substantial change or cancellation of the coverage. The State shall seek to cause DOE to require its contractors that are to perform maintenance on Tract B-2E to provide Quivira, prior to Contractor entering upon Tract B-2E, Certificates of Insurance evidencing comprehensive general liability insurance of not less than $\$ 1$ million insuring against claims for injuries and property damage, and providing for 30 days prior notice by the insurance company to Quivira of substantial change or cancellation of the coverage.

\section{ENTIRE AGREDMENT:}

This easement and agreement shall constitute the entire agreement between the parties and any prior understanding or representation of any kind preceding the date of this agreement shall not be binding on either party except to the extent incorporated in this agreement.

\section{EFEECTIVE DATE:}

This easement shall not be effective until executed by the parties and approved as to form by the New Mexico State Board of Finance. By granting and accepting this easement, the state and Quivira and their successors and assigns agree to be bound by the terms of the easement grant and agree that the parties shall be entitled to specific performance of any of the provisions or conditions thereof in any court of competent jurisdiction if the curing of any violation has not occurred within thirty (30) days after the party has provided written notice to the violating party of said violations or deficiencies.

TO HAVE AND TO HOLD the easement hereby granted to the state and its successors and assigns forever but without warranties of any kind by Quivira except that Quivira affirmatively states it has received no claims to ownership from anyone since it has acquired title to the property, and that it has not conveyed or incurred any liens against the property, and Quivira further states that it has the authority to enter into this Agreement.

In witness whereof, the parties have hereunto set their hands on the day and year below written.

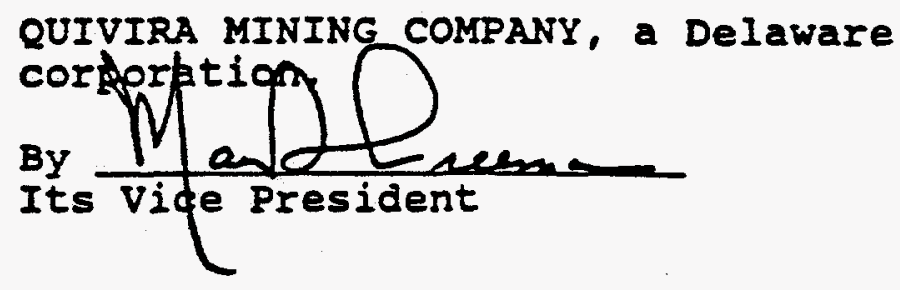




\section{5}

WEW MEXICO GENERAL SPRYICES DEPARTIENT

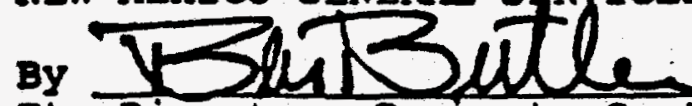

Its Director, Property Control Division

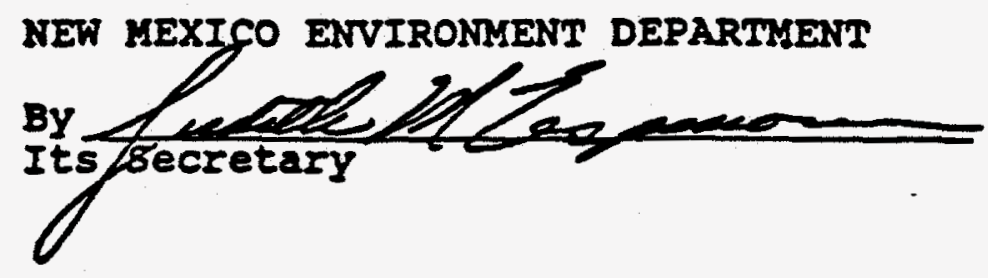




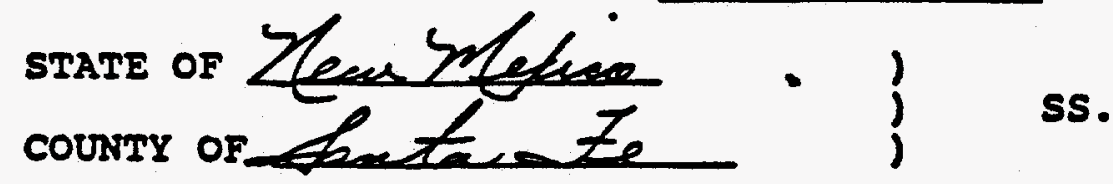

The foregoing instrument was acknowledged before me this $30 \mathbb{K}$ day of Lail . 1992, by Marvin D. Freeman, Vice President of Quivira Mining Company, a Delaware corporation, on behalf of said corporation.

My commission expires: $2 / 28 / 66$ (Seal)<smiles>C#CCCCCC#C</smiles>

STATE OF NEW MEXICO

COUNTY OF SANTA FE

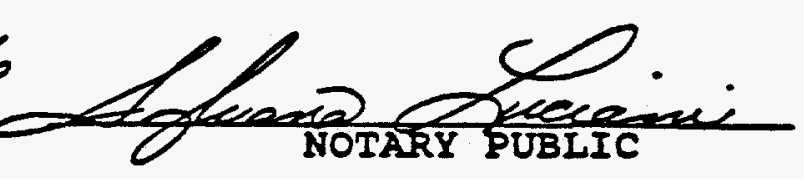

\section{ACKNOWLEDGENENT}

\} ss.

The foregoing instrument was acknowledged before me this 28 th day of Genil ' 1992, by 3 en bech, Director, Property Control Division, New Mexico General Services Department, on behalf of said agency.

My commission expires: $1 / 3 / / 43$ (Seal)

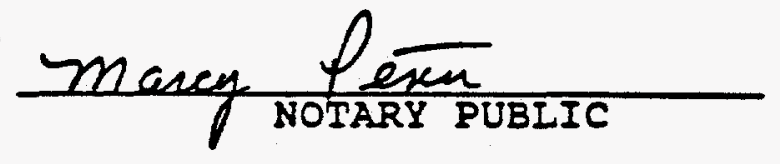

\section{ACKNOWLEDGEMENT}

STATE OF NEY MEXICO

COUNTY OF SANTA FE

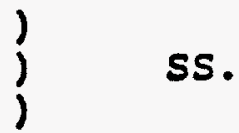

The foregojng instrument was acknowledged before me this $30 \mathbb{Z}$ day of Les if. 1992, by Judith M. Espinosa, Secretary of New Kexico Exvironment Department, on behalf of said agency.

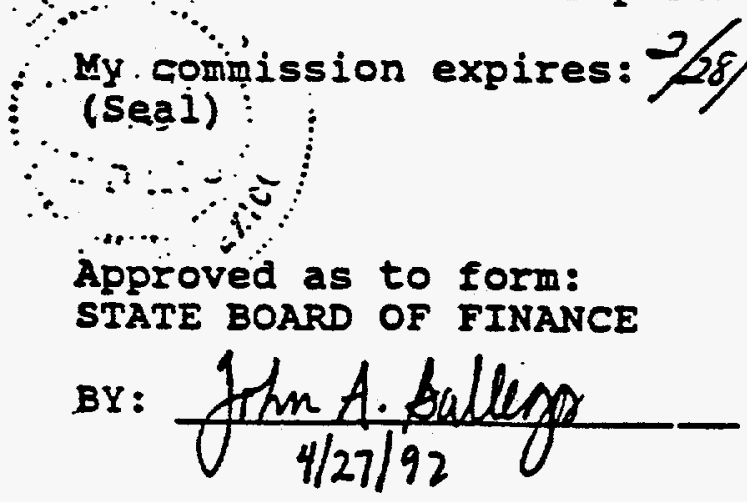


ATTACHMENT 3

SITE INSPECTION PHOTO LOG 


\section{SITE INSPECTION PHOTO LOG}

Site: Site Activity:

Date: Time of Day: From to

Weather Conditions:

Roll Number: Film Type: Number of Exposures

Photo Number
Location

Description 


\section{SITE INSPECTION PHOTO LOG (CONT.)}

\section{Site}

Date

\section{Photo Number}

Location

Description

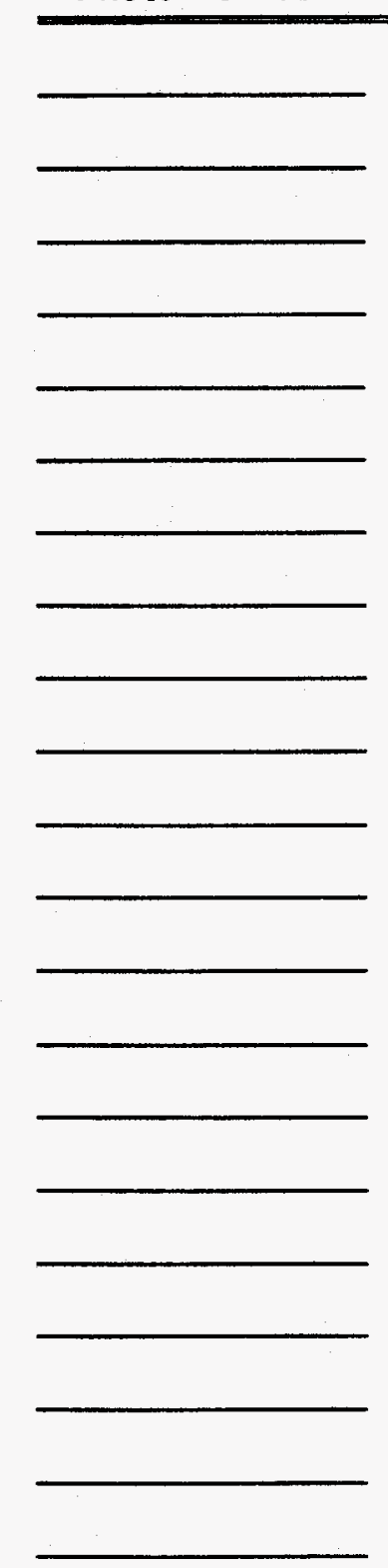

Photographer:

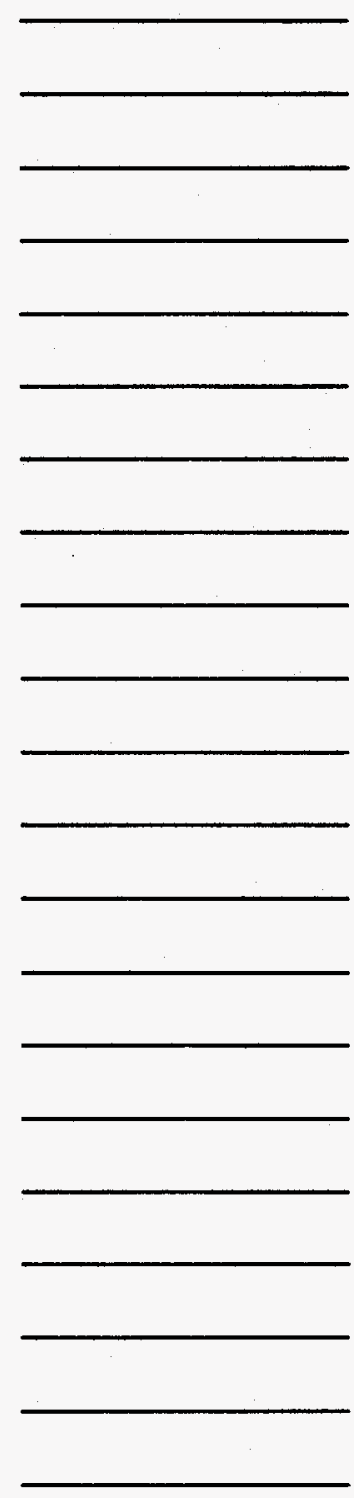

\section{Signature}




\section{ATTACHMENT 4}

\section{SITE INSPECTION CHECKLIST}




\section{SITE INSPECTION CHECKLIST FOR THE AMBROSIA LAKE, NEW MEXICO, URANIUM MILL TAILINGS DISPOSAL SITE}

Date of Last Inspection:

Reason for Last Inspection:

Responsible Agency*: DOE Grand Junction Projects Office

Address: P.O. Box 2567, Grand Junction, Colorado 81502-2567

Responsible Agency Official:

Inspection Start Date and Time:

Weather Conditions at Site:

Inspection Completion Date and Time:

Chief Inspector:

Name Title Organization

Assistant Inspector:

Name Title Organization

\section{A. GENERAL INSTRUCTIONS}

1. All checklist items must be completed and detailed comments made to document the results of the site inspection. The completed checklist is part of the field record of the inspection. Additional pages should be used, as necessary, to ensure that a complete record is made. Attach the additional pages and number all pages upon completion of the inspection.

2. Inspectors are to provide an up-to-date résumé or vitae for inclusion in the inspection report.

3. Any checklist line item marked by an "* " that is checked by an inspector must be fully explained or an appropriate reference to previous reports provided. The purpose of this requirement is to provide a written explanation of inspector observations and the inspector's rationale for conclusions and recommendations. Explanations are to be placed on additional attachments and cross-referenced appropriately. Explanations, in addition to narrative, will take the form of sketches, measurements, and annotated site atlas overlays.

4. The site inspection is a walking inspection of the entire site, including the perimeter and sufficient transects to be able to inspect the entire surface and all features specifically described in this checklist. Every monument, site marker, sign, monitoring well, and erosion control marker will be inspected.

\footnotetext{
'Responsibility for site inspections assigned by DOE UMTRA Project, Albuquerque, to DOE Grand Junction Projects Office, November 6, 1990. 
5. A set of color print $35-\mathrm{mm}$ photographs is required. Sufficient photographs will be taken to compare to baseline photographs and determine if there are any significant differences in site appearance. In addition, all anomalous features or new features (such as changes in adjacent area land use) are to be photographed. A photo log entry will be made for each photograph taken.

6. Field notes taken to assist in completion of this checklist will become part of the inspection record. No form is specified; the field notes must be legible and in sufficient detail to enable review by succeeding inspectors and the responsible agency.

B. PREPARATION (to be completed prior to site visit)

1. License (includes Long-Term Surveillance and Maintenance Plan) reviewed.

2. Site as-built plans reviewed and base map with copies of the following site atlas overlays obtained:

a. Adjacent off-site features and land use; fences, gates, and signs; access roads and paths.

b. Survey monuments, boundary markers, site markers, aerial photo ground controls, ground photo locations.

c. Monitoring wells, site drainage, diversion channels.

d. Planned inspection transects and vegetation cover.

e. Others.

These overlays will be used to identify site features and record, as appropriate, field data.

3. Previous inspection reports reviewed.

a. Were anomalies or trends in modifying processes detected on previous inspections?

b. Was a Phase II inspection conducted?

c. Was custodial maintenance performed?

d. Was contingency repair work done as a result of the Phase II inspection? 
4. Site custodial maintenance and contingency repair records reviewed.

a. Has site contingency repair resulted in a change from as-built conditions?

b. Are reviewed as-builts available that reflect contingency repair changes?

5. If required, adjacent property entry approval obtained (attach signed access agreement).

6. Aerial photos, if taken since last inspection, reviewed. For each set, enter date taken, scale, and if interpreted.

Set

Date

Scale

1.

2.

3.
Interpreted

Yes No

Yes No

7. Were any of the following suggested by examination of aerial photographs? (If yes, give photo set date and indicate if item noted by interpreter or inspector):
a. Intrusion by man?
b. Intrusion by animals?
c. Channelized erosion on slopes?
d. Change in area drainage?
e. Landslides?
f. Creep on slopes?
g. Obstruction of diversion channels?
h. Bank erosion of diversion channels?
i. Seepage? 
j. Cracking?

Yes No

k. Change in vegetative cover?

I. Displacement of fences, site markers, boundary markers, or monuments?

m. Change in adjacent land use?

n. Evidence of tailings exposure or transport?

8. From as-builts, or subsequent inspection reports, note distance and azimuth from designated site location, such as a monument, to adjacent off-site features that could eventually affect integrity of site.

Off-site feature

1.

2.

3

9. Assemble and check out the following equipment, as needed, to conduct inspections:

a. Cameras, film, and miscellaneous support equipment.

b. Binoculars.

c. Tape measure.

d. Optical ranging device.

e. Brunton compass.

f. Photo scale stick.

g. Erasable board.

h. Plant press, plastic bags for vegetation.

i. Keys to locks.

j. Bolt cutters.

k. Hand lens.

I. Clipboard.

m. Others. 


\section{SITE INSPECTION}

1. Adjacent off-site features (within 0.25 mile [0.4 meter] of site boundary)

a. Have there been any changes in use of adjacent areas (grazing, construction, agriculture)?

b. Are there any new roads or trails?

c. Has there been a change in the position of nearby stream channels?

d. Has there been headward erosion of nearby gullies?

e. Are there new drainage channels?

f. Others?

2. Access roads and paths, fences, gates, and signs.

a. Is there a break in the fence?

b. Have any posts been damaged or their anchoring weakened?

c. Is there evidence of erosion or digging beneath the fence?

d. Does the gate show evidence of tampering or damage?

e. Is there any evidence of human intrusion?

f. Is there any evidence of large animal intrusion?

g. Have any signs been damaged or removed? (Number of signs replaced:

h. Are access roads and paths passable?

i. Others? 
3. Monuments and other permanent features.

a. Have the survey or boundary monuments been defaced or disturbed?

b. Have the site markers been disturbed by man or natural processes?

c. Do natural processes threaten the integrity of any monument or site marker?

d. Others?

4. Crest.

Yes $\quad$ No

a. Is there evidence of uneven settling?

(depressions, scarps)

b. Is there cracking?

c. Has the outer cover layer been breached?

d. Is there evidence of erosion?

1) By water? (rills, rivulets)

2) By wind? (pedestal rocks, ripple marks)

e. Is the vegetation cover as described in the as-builts?

f. Is there evidence of animal burrowing?

g. Others?

5. Slopes.

a. Is there evidence of gradual downslope movement (creep)? (terraces, deflection of plants)

b. Is there cracking?

c. Can depressions or bulges on the slope be seen? 
d. Has the outer cover layer been breached?

e. Is there evidence of erosion:

1) By water?

2) By wind?

f. Has water runoff become channelized? (rivulets, gullies)

g. Is there evidence of seepage? (moisture, color, vegetation)

h. Has the vegetation cover changed significantly since the last inspection?

i. Is there evidence of animal burrowing?

j. Is there evidence of deterioration of riprap or gravel cover?

k. Others?

6. Periphery (within site boundaries).

a. Is there evidence of seepage such as wet areas or localized change of vegetation?

b. Is there evidence of sediment transport from the tailings pile by water or wind?

c. Is the vegetative cover as described in the as-builts?

d. Is the drainage as described in the as-builts?

e. Others? Burrowing animals; erosion.

7. Diversion channels.

a. Is there evidence of bank erosion? 
b. Has the integrity of riprap structures been disturbed by people or natural processes?

c. Is there evidence of channel erosion?

d. Is there evidence of sedimentation in the channel?

e. Is the channel obstructed in any way?

f. Is there any evidence that the diversion channels are not performing their function?

g. Others?

8. Photography.

a. Have all photos required by the site atlas photo overlay been taken?

b. Has a photo log sheet been prepared for each roll of film exposed?

c. Number of rolls of film exposed:

d. Others?

9. Monitor wells.

a. Have any monitor wells been disturbed by man or natural processes?

b. Does any natural process threaten the integrity of any monitor well?

C. Are all monitor wells capped and locked?

d. Others? 


\section{FIELD CONCLUSIONS}

1. Is there an imminent hazard to the integrity of the

Yes No tailings pile? (Immediate report required)

Person/Agency to whom report made:

2. Are more frequent routine inspections required?

3. Are existing contingency repair actions satisfactory?

4. Is a follow-up inspection required?

5. Is a preliminary assessment report or custodial maintenance required?

6. Rationale for field conclusions are documented as the text of this report.

\section{E. CERTIFICATION}

I have conducted a prelicensing inspection of the Ambrosia Lake, New Mexico, uranium mill tailings disposal site in accordance with the procedures of the license (includes the site surveillance plan) as recorded on this checklist, attached sheets, field notes, photo log sheets, and photos. 


\section{ATTACHMENT 5}

\section{AGENCY NOTIFICATION AGREEMENTS}




\section{DRAFT}

McKinley County Sheriff's Office

2105 E. Aztec Avenue

Gallup, New Mexico 87301

Dear Sheriff :

The U.S. Department of Energy (DOE) Uranium Mill Tailings Remedial Action Project is requesting notification in the event of any unusual activities or events in south-central McKinley County, New Mexico, around the DOE's Ambrosia Lake uranium mill tailings disposal site. The site is located approximately 25 miles north of Grants, New Mexico, just east of State Highway 509 about 5 miles from its junction with State Highway 605 (see enclosed map).

The purpose of the notification request is to assist the DOE in monitoring and maintaining the integrity of the Ambrosia Lake disposal site and to ensure public safety.

If during the course of routine activities, anything out of the ordinary that could potentially impact the site is observed by your staff or reported to your office, we would appreciate notification to the DOE Grand Junction Projects Office's 24-hour phone line at (970) 2486070.

If the notification request discussed above is agreeable to you, please sign and return the attached reply letter for our records as soon as possible.

Should you have any questions, please contact me at (505) 845-5758. Thank you for your attention in this matter.

Mike Abrams

Project Site Manager

Environmental Restoration Division

U.S. Department of Energy

Enclosures

cc: w/o enclosures

SWright (TAC)

SHamp (ERD)

CJones (RUST Geotech)

MHansen (TAC)

AVollmer (TAC)

JVirgona (GJPO) 


\section{DRAFT}

Mike Abrams

Project Site Manager

Environmental Restoration Division

U.S. Department of Energy

P.O. Box 5400

Albuquerque, NM 87115

Dear Mr. Abrams:

This letter is to concur with the U.S. Department of Energy (DOE) request for notification as set forth in the DOE's letter. As requested in your letter, this office will contact the DOE's Grand Junction Projects Office at (970) 248-6070 if any unusual event or anomaly is observed or reported at or around the DOE's Ambrosia Lake disposal site, McKinley County, New Mexico.

Sincerely,

McKinley County Sheriff

cc: SWright (TAC)

SHamp (ERD)

CJones (RUST Geotech)

MHansen (TAC)

AVollmer (TAC)

JVirgona (GJPO) 


\section{DRAFT}

Charlie Liles

Area Manager

National Weather Service

Albuquerque, New Mexico 87119

Dear Mr. Liles:

The U.S. Department of Energy (DOE) Uranium Mill Tailings Remedial Action Project is requesting notification in the event of issuance of flash flood or tornado warnings in southcentral McKinley County, New Mexico. We would appreciate notification to the DOE Grand Junction Projects Office's 24-hour phone line at (970) 248-6070 within 8 hours of issuance of a warning or episode of warnings.

The purpose of this warning is to assist the DOE in monitoring and maintaining the integrity of its Ambrosia Lake uranium mill tailings disposal site located north of Grants, New Mexico, about 5 miles northwest of the junction of State Highways 509 and 605 (see enclosed map).

If the notification request discussed above is agreeable to you, please sign and return the enclosed reply letter for our records as soon as possible.

Should you have any questions, please contact me at (505) 845-5637.

Sincerely,

Mike Abrams

Project Site Manager

Environmental Restoration Division

U.S. Department of Energy

Enclosures

cc: w/o enclosures

SWright (TAC)

SHamp (ERD)

CJones (RUST Geotech)

MHansen (TAC)

AVollmer (TAC)

JVirgona (GJPO) 


\section{DRAFT}

\section{Mike Abrams}

Project Site Manager

Environmental Restoration Division

U.S. Department of Energy

P.O. Box 5400

Albuquerque, New Mexico 87115

Dear Mr. Abrams:

This letter is to concur with the U.S. Department of Energy (DOE) request for notification as set forth in the DOE's letter. As requested in your letter, this office will contact the Grand Junction Projects Office at (970) 248-6070 in the event of issuance of a flash flood or tornado warning in south-central McKinley, New Mexico.

Sincerely,

Charlie Liles

Area Manager

National Weather Service

cc: SWright (TAC)

SHamp (ERD)

CJones (RUST Geotech

MHansen (TAC)

AVollmer (TAC)

JVirgona (GJPO) 


\section{National Earthquake Information Center \\ World Data Center A for Seismology}

\author{
Director \\ (303) 236-1510 \\ Research \\ (B03) 236-1506
}

\author{
c.s. Geological Surrey \\ Box 25046. DFC. US-96; \\ Dequer. Colorado 80025 USA \\ Telex: (NTTCO) 5106014123ESL LD
}

\author{
Operations \\ (303) 236-1500 \\ QED \\ (c00) 358-2663
}

Clinton C. Smythe

Engineering and Construction Group Leader

Uranium Mill Tailings Remedial Action

Project Office

2155 Louisiana NE, Suite 4,000

Albuquerque, NM 87110

Dear inr. Smythe:

This letter is to confirm that the DOE Grand Junction Projects Office (24-hour phone line, (303) 248-6070 has been added to our notification list for the occurrence of earthquakes near the following locations:

\begin{tabular}{|c|c|c|}
\hline Disposal Site & Latitude & Longitude \\
\hline \multicolumn{3}{|l|}{ COLORADO } \\
\hline Durango (Bodo Canvon) & N37.15 & W107.90 \\
\hline Grand Junction & N38.91 & W108.32 \\
\hline Gunnison (Landfill) & N38.51 & W106.85 \\
\hline Maybell & N40.55 & W107.99 \\
\hline Naturita (Dry Flats) & N38.21 & W108.60 \\
\hline Rifle (Estes Gulch) & N39.60 & W107.82 \\
\hline Slick Rock (Burro Canyon) & N38.05 & W108.87 \\
\hline \multicolumn{3}{|l|}{ IDAHO } \\
\hline Lowman & $\mathbf{N} 44.16$ & W115.61 \\
\hline \multicolumn{3}{|l|}{ NEW MEXICO } \\
\hline Ambrosia Lake & N35.41 & W107.80 \\
\hline \multicolumn{3}{|l|}{ NORTHDAKOTA } \\
\hline Bowman & $\mathrm{N} 46.23$ & W103.55 \\
\hline \multicolumn{3}{|l|}{ OREGON } \\
\hline Lakeview (Collins Ranch) & $\mathbf{N 4 2 . 2}$ & W120.3 \\
\hline \multicolumn{3}{|l|}{ PENNSYLVANLA } \\
\hline Canonsburg & $\mathrm{N} 40.26$ & W80.25 \\
\hline Burrell VP & N40.62 & W79.65 \\
\hline \multicolumn{3}{|l|}{ TEXAS } \\
\hline Falls City & N28.91 & W98.13 \\
\hline \multicolumn{3}{|l|}{ UTAH } \\
\hline Mexican Hat & $\mathbf{N 3 7 . 1 0}$ & W109.85 \\
\hline Salt Lake Citv (Clive) & N40.69 & W113.11 \\
\hline
\end{tabular}


National Earthquake Information Center. World Data Center A for Seismology

Director

(303) 236-1510

Research

(803) 236-1506
U.S. Geologies Survey

Bax 2046, DFC, MS -967

Denver, Colorado 80025 USA

Telex: (WTTCO) 6106014123ESL CD

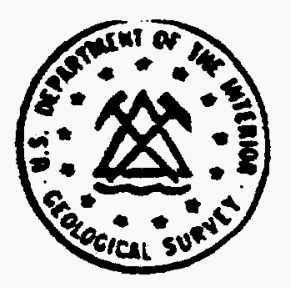

Operations

(303) 236-1500

QED

(800) 358-2663

Clinton C. Smythe

$-2-$

We have entered the following selection criteria into our notification program:

1. Any earthquake of magnitude 3.0 or greater, within 0.3 degrees (about 20 miles) of any site shown above, or

2. Any earthquake of magnitude 5.0 or greater, within 1.0 degrees (about 70 miles) of any site shown above.

Sincerely,

Sine wo Pregerare

Bice Presgrave

U.S. Geological Survey

National Earthquake Information Center

P.O. Box 25046

Mail Stop 967

Denver Federal Center

Denver, Colorado 80225

Please adders future comespondence to shirt Koyanagi at the above address. I have moved to a different project.

Thank you + best regards,

Hence Peugene

A5-6 
N1,607,000

Ann Lee Mine

(closed)

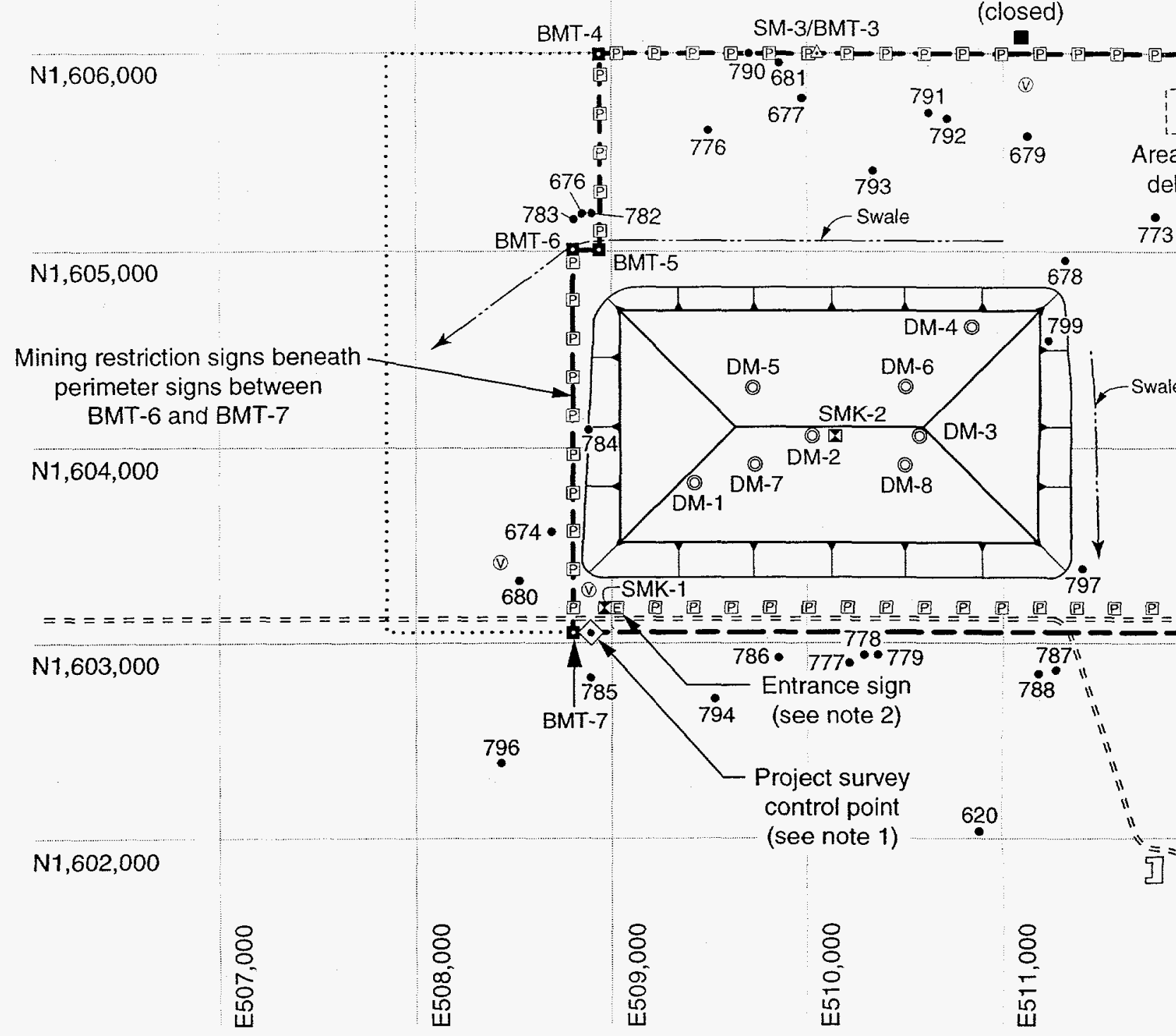

Legend

- 620 Monitor well

- Property boundary

...... Restrictive easement boundary SM-3/BMT-3

DM-10
Permanent survey/boundary monument

Displacement monument
Project survey control
point monument

BMT-8 Permanent boundary monument

(v) Sealed mine vent

$===$ Existing dirt road 
1. Project survey control point $(N 1,603,044.66, E 508,896.46)$ is located at the S.W. corner of Section $28, T 14 N$, R9W, New

Mexico Prime Meridian. New Mexico Western Region

State Plane Coordinate Grid System shown.

2. Perimeter and entrance signs were located 10 feet ( 3 meters) inside the west, north, and east site boundary, and 120 feet (3.7 meters) inside the south site boundary. The entrance sign was located near SMK-1. Perimeter and entrance signs were spaced 200 ieet (61 meters) apart beginning at the southwest corner of the site and proceeding counterclockwise.

\section{Disposal cell}

Site marker

Perimeter sign

Entrance sign

Construction grid
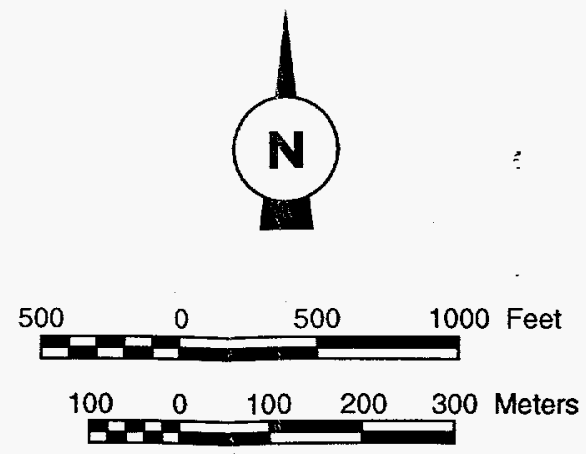

From MKF, 1995. 